\title{
Interpretation of Chemical and Isotopic Data \\ From Boreholes in the Unsaturated Zone at Yucca Mountain, Nevada
}

by In C. Yang1, Gordon W. Rattray', and Pei Yu2

1U.S. Geological Survey, Denver, Colorado

2University of Colorado, Boulder, Colorado

\section{U.S. GEOLOGICAL SURVEY}

Water-Resources Investigations Report 96-4058

Prepared in cooperation with the

NEVADA OPERATIONS OFFICE,

U.S. DEPARTMENT OF ENERGY, under

Interagency Agreement DE-Al08-78ET44802

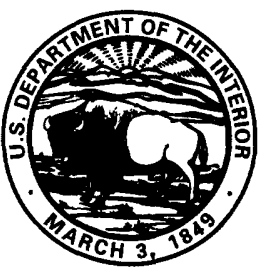




\section{U.S. DEPARTMENT OF THE INTERIOR BRUCE BABBITT, Secretary \\ U.S. GEOLOGICAL SURVEY \\ Gordon P. Eaton, Director}

The use of trade, product, industry, or firm names is for descriptive purposes only and does not imply endorsement by the U.S. Government.

For additional information write to:

Chief, Earth Science Investigations Program

Yucca Mountain Project Branch

U.S. Geological Survey

Box 25046, MS 421

Denver Federal Center

Denver, Colorado 80225
Copies of this report can be purchased from:

U.S. Geological Survey

Branch of Information Services

Box 25286

Denver, Colorado 80225 


\section{CONTENTS}

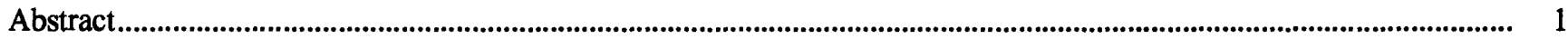

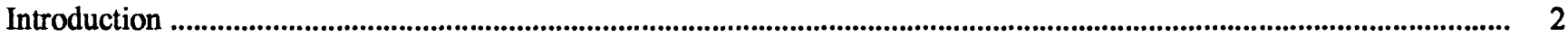

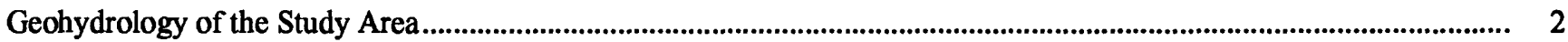

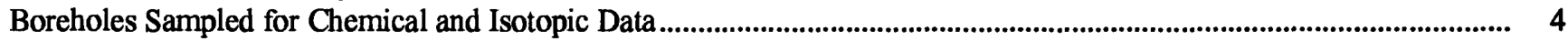

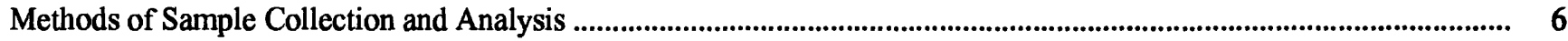

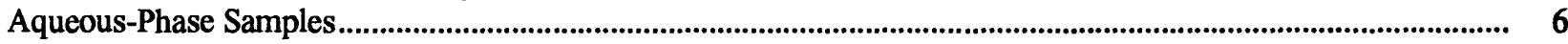

Extraction of Pore Water from Core Samples ...................................................................................................... 6

Collection of Perched and Saturated-Zone Water Samples.................................................................................... 7

Analyses of Water Samples ............................................................................................................................................. 7

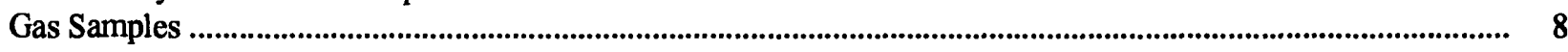

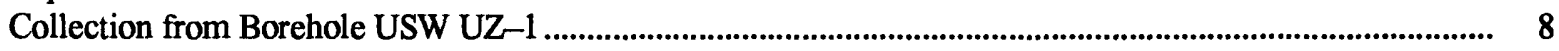

Collection from Open Boreholes................................................................................................................ 11

Analysis of Gas Samples ............................................................................................................................. 11

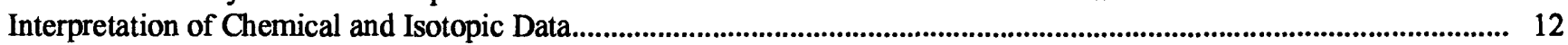

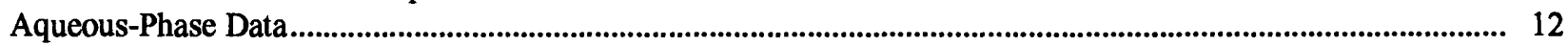

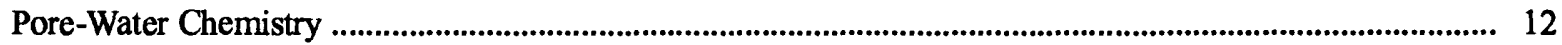

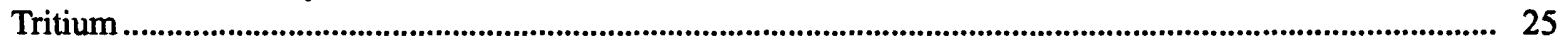

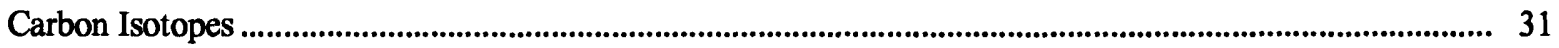

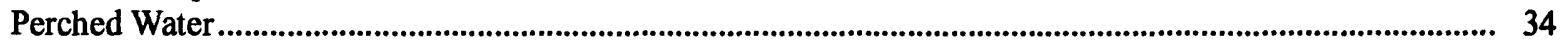

Gaseous-Phase Data from Borehole USW UZ-1 .................................................................................................. 40

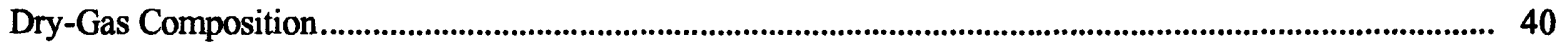

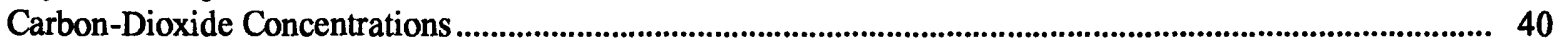

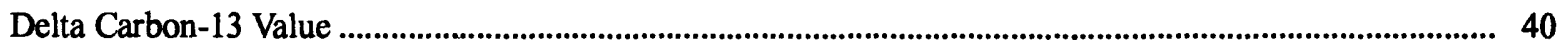

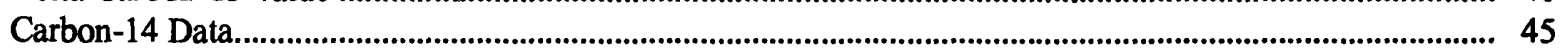

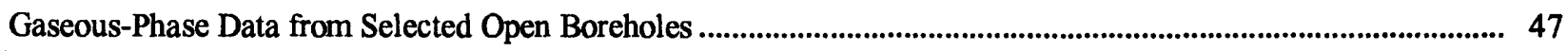

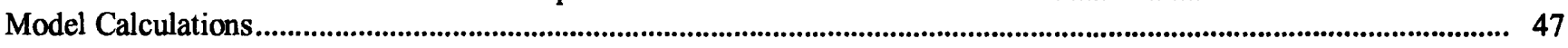

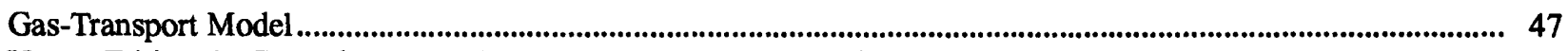

Use of Tritium in Ground Water to Determine Water Mean Residence Times......................................................... 49

Piston-Flow, or Preferential-Flow, Model .............................................................................................. 49

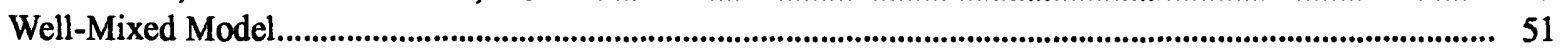

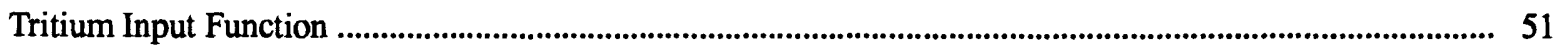

Results of Tritium Model Calculations.................................................................................................. 52

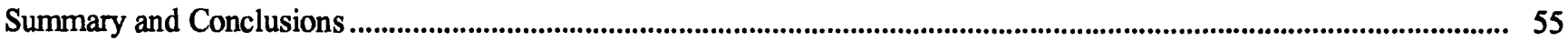

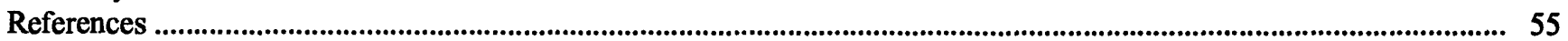

\section{FIGURES}

1. Diagram showing hydrogeologic units at Yucca Mountain, Nevada .................................................................. 3

2. Maps showing locations of unsaturated-zone boreholes at Yucca Mountain, Nevada ............................................. 5

3. Diagram showing gas-sampling system .......................................................................................................... 9

4. Diagram showing system for separation of carbon dioxide from air for whole-gas samples .................................... 10

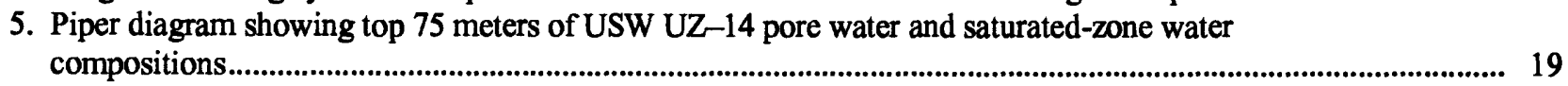

6. Piper diagram showing (A) USW NRG-6 and 7a pore-water composition, and (B) composition of lithologic contacts and adjacent beds from USW NRG-6, 7a, and unsaturated-zone holes ............................... 20

7. Piper diagram showing pore-water composition of (A) USW UZ-14 and (B) UE-25 UZ\#16................................ 22 
8-11. Graphs showing:

8. Lithologic units, water content, and tritium concentrations of boreholes (A) UE-25 UZ\#4 and (B) UZ\#5

9. Tritium and carbon-14 data from USW UZ-14 pore water and rock-gas carbon-14 data from USW UZ-1

10. Lithologic units, tritium, and carbon-14 concentrations of boreholes: (A) USW NRG-6 and (B) USW NRG-7a

11. Lithologic units, tritium, and carbon-14 concentrations of borehole UE-25 UZ\#16.

12. Expanded graph of tritium, carbon-14, and carbon-13 data from figure 11, UE-25 UZ\#16.

13. Expanded graph of carbon-14 and carbon-13 from USW UZ-14: (A) top 122 meters and

(B) Calico Hills Formation 30

14. Piper diagram showing perched-water composition, along with saturated-zone water compositions

15-23. Graphs showing:

15. (A) Apparent carbon-14 percent modern carbon of perched waters, and (B) delta carbon-13 values of perched waters

16. Delta oxygen- 18 compared to delta deuterium plot of saturated-zone water and perched water

17. Sulfur hexafluoride concentration in parts per million from USW UZ-1, 1984-94

18. Percent carbon dioxide concentration from borehole USW UZ-1: (A) 1983-87 and (B) 1988-94 .............. 43

19. Delta carbon-13 values in per mil from borehole USW UZ-1: (A) 1984-87 and (B) 1988-94 .................... 44

20. Carbon-14 activity in carbon dioxide gas from borehole USW UZ-1: (A) 1984-87 and (B) 1988-94 ........ 46

21. Diffusion model calculated and observed ${ }^{14} \mathrm{CO}_{2}$ concentration relative to depth in USW UZ-1 ................... 50

22. Tritium input function derived from (A) annual mean value, and (B) highest monthly value in a year of tritium concentration in precipitation from four stations: Albuquerque, New Mexico; Flagstaff, Arizona; Menlo Park, California; and Salt Lake City, Utah

23. Calculated tritium contents of water in the unsaturated zone by piston-flow and well-mixed models using (A) annual mean value of tritium input function, and (B) highest monthly value of tritium input function

\section{TABLES}

1. Summary of relation of gravimetric water-content measurements of composite core to geologic unit and degree of welding for boreholes UE-25 UZ\#4 and UE-25 UZ\#5, Yucca Mountain, Nevada.

2. Chemical composition of pore-water and ground-water samples from boreholes UE-25 UZ\#16, UE-25 UZ-N2, and UZ-N46, Yucca Mountain, Nevada

3. Chemical composition of pore-water samples from borehole USW UZ-14, Yucca Mountain, Nevada ................ 16

4. Chemical composition of pore-water and ground-water samples from borehole NRG-6/7a, Yucca Mountain, Nevada

5. Comparison of pore-water composition in lithologic contacts and adjacent beds, Yucca Mountain, Nevada

6. Chemical composition of perched water at Yucca Mountain, Nevada.

7. Isotopic composition of perched water

8. USW UZ-1 dry-gas composition

9. Carbon-14 and delta carbon-13 data from boreholes NRG-6, NRG-7a, UZ-16, and SD-12 


\section{CONVERSION FACTORS}

Metric (International System) units in this report may be converted to inch-pound units by using the following conversion factors:

\begin{tabular}{rll}
\hline Multiply metric unit & \multicolumn{1}{c}{ By } & To obtain inch-pound unit \\
\hline nanometer $(\mathrm{nm})$ & $3.937 \times 10^{-8}$ & inch \\
centimeter $(\mathrm{cm})$ & $3.937 \times 10^{-1}$ & inch \\
cubic centimeter $\left(\mathrm{cm}^{3}\right)$ & $6.102 \times 10^{-2}$ & cubic inch \\
cubic meter $\left(\mathrm{m}^{3}\right)$ & $6.102 \times 10^{4}$ & cubic inch \\
gram $(\mathrm{g})$ & $2.2 \times 10^{-3}$ & pound, mass \\
gram per cubic centimeter $\left(\mathrm{g} / \mathrm{cm}^{3}\right)$ & $3.6 \times 10^{-2}$ & pound per cubic inch \\
kilometer squared $\left(\mathrm{km}^{2}\right)$ & $1.076 \times 10^{7}$ & square foot \\
kilometer $(\mathrm{km})$ & $6.214 \times 10^{-1}$ & mile \\
kilopascal $(\mathrm{kPa})$ & 0.145 & pound-force per square inch \\
$\operatorname{liter}(\mathrm{L})$ & 0.2642 & gallon \\
liter per minute $(\mathrm{L} / \mathrm{min})$ & 0.2642 & gallon per minute \\
megapascal $(\mathrm{MPa})$ & 144.7 & pound per square inch \\
$\mathrm{meter}(\mathrm{m})$ & 3.281 & foot \\
meter per day $(\mathrm{m} / \mathrm{d})$ & 3.281 & foot per day \\
microgram per liter $(\mu \mathrm{g} / \mathrm{L})$ & 1 & part per billion \\
milligram $(\mathrm{mg})$ & $2.2 \times 10^{-6}$ & pound \\
milligram per liter $(\mathrm{mg} / \mathrm{L})$ & 1 & part per million \\
milliliter $(\mathrm{mL})$ & $6.102 \times 10^{-2}$ & cubic inch \\
millimeter $(\mathrm{mm})$ & $3.937 \times 10^{-2}$ & inch \\
\hline
\end{tabular}

To convert degree Celsius $\left({ }^{\circ} \mathrm{C}\right)$ to degree Fahrenheit $\left({ }^{\circ} \mathrm{F}\right)$ use the following formula:

$$
{ }^{\circ} \mathrm{F}=9 / 5\left({ }^{\circ} \mathrm{C}\right)+32
$$




\title{
Interpretation of Chemical and Isotopic Data from Boreholes in the Unsaturated Zone at Yucca Mountain, Nevada
}

\author{
By In C. Yang, Gordon W. Rattray, and Pei Yu
}

\begin{abstract}
Analyses of pore water from boreholes at Yucca Mountain indicate that unsaturatedzone pore water has significantly larger concentrations of chloride and dissolved solids than the saturated-zone water or perched-water bodies. Chemical compositions are of the calcium sulfate or calcium chloride types in the Paintbrush Group (Tiva Canyon, Yucca Mountain, Pah Canyon, and bedded tuffs), and sodium carbonate or bicarbonate type water in the Calico Hills Formation.

Tritium profiles from boreholes at Yucca Mountain indicate tritium-concentration inversions (larger tritium concentrations are located below the smaller tritium concentration in a vertical profile) occur in many places. These inversions indicate preferential flow through fractures. Large carbon-14 variations of about 53.0 to 97.7 percent modern carbon are seen in UE-25 UZ\#16 bedded tuff and in the Calico Hills Formation. The larger value of 97.7 percent modern carbon and modern chlorine-36 values obtained from pore water and core cuttings from the Calico Hills Formation of UE-25 UZ\#16 are in the same locations where large tritium concentrations are found.

The apparent carbon-14 ages of perched water range from 3,000 to 10,800 years. If age corrections are made to account for caliche dissolution, perched-water residence times all will be less than 7,000 years. Stable isotopic values of -12.1 to -13.8 parts per thousand for delta oxygen-18 and -87.4 to -100 per mil for delta
\end{abstract}

deuterium in perched water are not consistent with recharge during colder climates and therefore strongly support carbon- 14 mean ages of less than 7,000 years. Major-ion chemistry of perched water indicates similar chemical compositions to the saturated-zone ground water except for USW UZ-14 perched water, which is typical of Topopah Spring Tuff water.

Rock-gas compositions are similar to that of atmospheric air except that carbon dioxide $\left(\mathrm{CO}_{2}\right)$ concentrations are generally larger than those in the air. The delta carbon-13 values of gas from USW UZ-1 are fairly constant from surface to 365.8 meters, indicating little interaction between the gas $\mathrm{CO}_{2}$ and caliche in the soil. Carbon-14 data of gaseous and aqueous phases also show little interaction between gas $\mathrm{CO}_{2}$ and caliche. With regard to gas-water exchange, an aqueous phase will affect a gaseous phase more because most carbon resides in the aqueous phase. The nonequilibrium condition observed between the two phases is likely caused by collecting most gas samples by pumping from dry fractures rather than from pore gas, which could have been in equilibrium with the pore water. Gas carbon-14 ages are significantly older than water carbon-14 ages in deep Topopah Spring Tuff and below. The observed apparent age differences may result from gravity-driven fracture flow of liquid, a process faster than the diffusion-controlled transport of gas. 
Model calculations indicate that the gas transport in the unsaturated zone at Yucca Mountain agrees well with the gas-diffusion process. Tritium-modeling results indicate that the high tritium value of about 100 tritium units in the Calico Hills Formation of UZ-16 is within limits of a piston-flow model with a water residence time of 32 to 35 years. The large variations in tritium concentrations with narrow peaks imply piston flow or preferential fracture flow rather than matrix flow. In reality, the aqueous-phase flow in the unsaturated zonc is between piston and well-mixed flows but is closer to a piston flow.

\section{INTRODUCTION}

The unsaturated zone (UZ) at Yucca Mountain in Nevada is being investigated as a potential site for a high-level nuclear-waste repository. A thorough understanding of geochemical and hydrologic processes in the UZ is essential for site characterization. The purpose of this report is to present gas and liquid hydrochemical data obtained to date and interpretations of these data related to the flow mechanisms and residence times of these fluids in the rock mass.

Data for the gaseous phase include carbon dioxide concentrations and carbon isotopic concentrations [carbon- $13\left({ }^{13} \mathrm{C}\right)$ and carbon- $14\left({ }^{14} \mathrm{C}\right)$ ] of rock gas probably from fractured tuffs. Data for the aqueous phase include major cation and anion concentrations and isotopic concentrations and compositions, which include tritium $\left({ }^{3} \mathrm{H}\right),{ }^{14} \mathrm{C},{ }^{13} \mathrm{C}$, deuterium $\left({ }^{2} \mathrm{H}\right)$, and oxygen- $\mathrm{I} 8\left({ }^{18} \mathrm{O}\right)$ of pore water in cores obtained from boreholes in the UZ. Pore-water compositions and carbon-14 data are mostly from bedded and nonwelded tuffs. In addition, perched-water bodies, when detected, also were analyzed for their chemical and isotopic compositions.

Most of the UZ boreholes are drilled in the washes on the east side of Yucca Mountain. From the present chemical and isotopic data, along with previously published USW UZ-1 data collected at Yucca Mountain (Yang and others, 1993), preliminary conceptual hydrologic-flow models are constructed from the data. Also, chemical compositions of pore water in different lithologic units are presented in Piper diagrams. The composition of pore water collected near the lithologic contacts and adjacent beds is reported and inferences to hydrologic flow are made. Finally, modeling of the gas-transport mechanism and tritium as a tracer in ground-water residence-time estimation was undertaken for the UZ of Yucca Mountain.

This investigation was conducted by the U.S. Geological Survey (USGS), in cooperation with the U.S. Department of Energy (DOE), under Interagency Agreement DE-AI08-78ET44802.

\section{GEOHYDROLOGY OF THE STUDY AREA}

Yucca Mountain is located near the western boundary of the Nevada Test Site in southern Nye County, Nevada. Along the crest of Yucca Mountain, altitudes generally range from 1,465 to $1,475 \mathrm{~m}$ (Montazer and Wilson, 1984). Yucca Mountain consists of a series of north-trending fault-block ridges composed of volcanic rocks that generally have an eastward tilt of $5^{\circ}$ to $10^{\circ}$ (Scott and Bonk, 1984). Numerous washes, generally underlain by alluvium, dissect the eastern side of the mountain. Average annual precipitation at the mountain is estimated to be about $150 \mathrm{~mm}$, and nearly three-fourths of the annual precipitation falls from October through April (Quiring, 1983). An unsaturated zone that is $500-700 \mathrm{~m}$ thick is present beneath Yucca Mountain. This zone consists of ashflow tuff that is extensively fractured, densely welded, minimally porous but transmissive, and is interbedded with argillic and zeolitic bedded tuff and ash-flow tuff that are less fractured, nonwelded, porous, and transmissive (Scott and Bonk, 1984). A generalized section of hydrogeologic units at Yucca Mountain is given in figure 1 . 


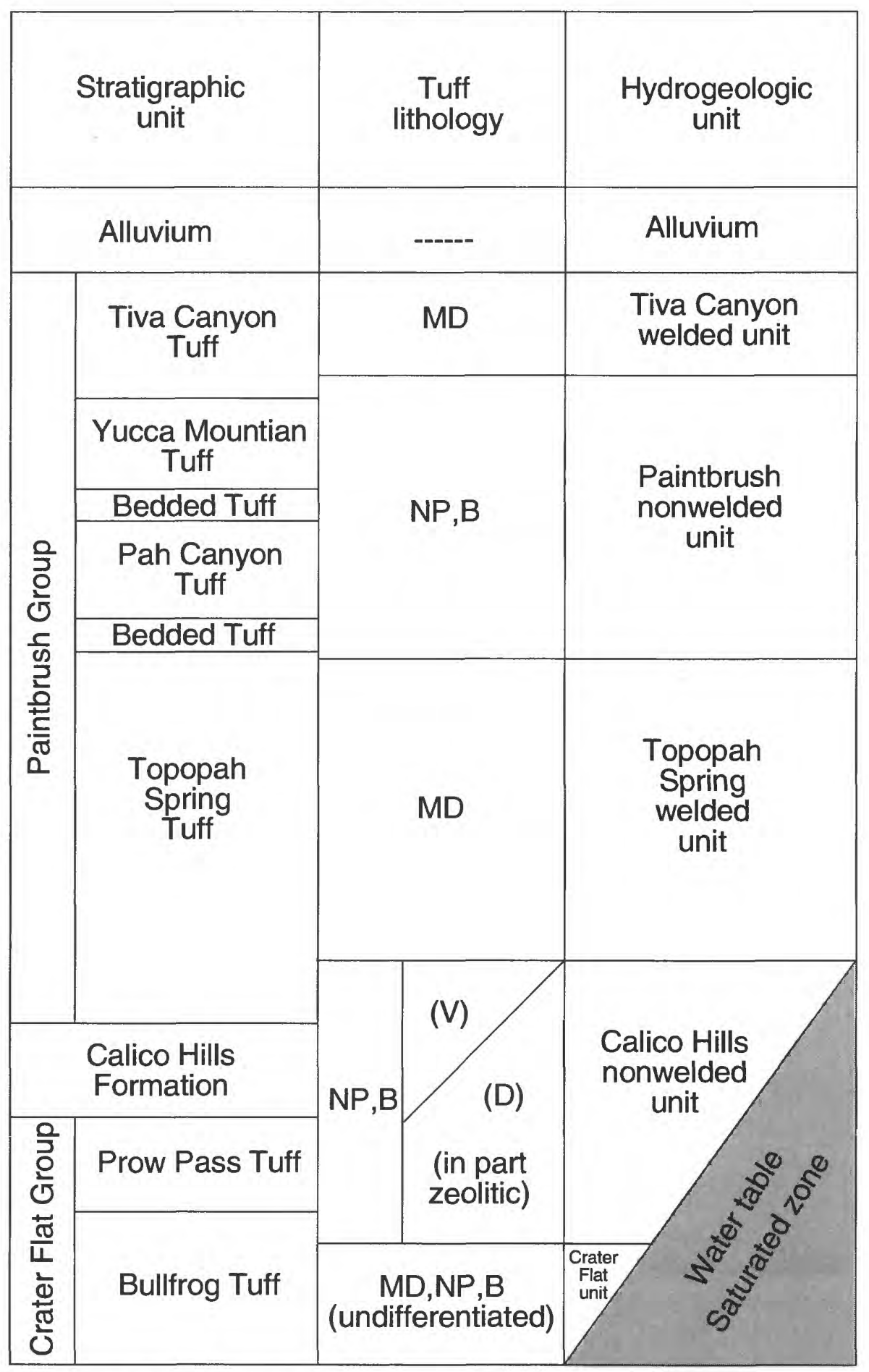

Flgure 1. Hydrogeologic units at Yucca Mountain, Nevada [modified from Montazer and Wilson (1984), table 1]. MD, moderately to densely welded; NP, nonwelded to partially welded; B, bedded; (V), vitric; (D), devitrified. 


\section{BOREHOLES SAMPLED FOR CHEMICAL AND ISOTOPIC DATA}

All UZ boreholes were drilled using the vacuum-reverse-air-circulation (VRAC) drilling method (Houghton, 1969). This method is intended to prevent the contamination of the unsaturated rocks with drilling fluids and thus allow the collection of native pore water and gas from the $\mathrm{UZ}$ for hydrochemical analyses. Sulfur hexafluoride $\left(\mathrm{SF}_{6}\right)$ was added to the compressed air stream injected into the annulus space between the inner and outer strings. The concentration of the $\mathrm{SF}_{6}$ in the air mixture was about 1.5 parts per million by volume (ppmv). Atmospheric gas that enters the formation during the drilling process can be removed later by evacuation of the borehole. Disappearance of the $\mathrm{SF}_{6}$ in the evacuated air assures the complete removal of the drilling air.

USW UZ-1 (fig. 2) was drilled from April through July of 1983 and completed to a total depth of $387.1 \mathrm{~m}$. Coring was attempted but was unsuccessful due to the use of an inappropriate coring bit (Whitfield, 1985). Only two pieces of core less than $0.61 \mathrm{~m}$ long each were recovered. Rocks of Quaternary and Tertiary ages were penetrated during the drilling of the borehole. The stratigraphy of the lithologic units penetrated is described in Whitfield and others (1990). The top $17.4 \mathrm{~m}$ consists of alluvium, which is underlain by three units in the Paintbrush Group: Yucca Mountain, Pah Canyon, and Topopah Spring Tuffs. These are thick, ash-flow tuff beds separated by bedded tuff units that are each $6 \mathrm{~m}$ thick. The tuff units are variously welded and indurated. Black glass shards were recovered during bailing when the borehole was $383.3 \mathrm{~m}$ deep, indicating the presence of friable, nonwelded tuff at the base of the Topopah Spring Tuff (Whitfield and others, 1990). The borehole contained 15 instrument and sampling stations upon completion. Each sampling station has a pressure transducer, thermocouple psychrometer, and gas-sampling tubes, isolated by silica flour and cement grout. Details of construction were given by Montazer and others (1985).

UE-25 UZ\#4 and UZ\#5 are located in Pagany Wash on the north-northeast side of Yucca Mountain. Borehole UZ\#4 is in the middle of the main wash and is about $37.7 \mathrm{~m}$ north of borehole UZ\#5. Borehole UZ\#5 is on the southern bank of the wash and about $3 \mathrm{~m}$ higher than borehole UZ\#4 (fig. 2). Borehole UZ\#4 drilling started September 6 and was completed October 10, 1984, to a depth of about $111.8 \mathrm{~m}$. The top $12 \mathrm{~m}$ of the borehole is in alluvial-colluvial material. Borehole UZ\#5 drilling started October 11 and was completed November 19, 1984, to a depth of about $111.6 \mathrm{~m}$. It is totally in bedrock. Details on the drilling of these two boreholes are given by Loskot and Hammermeister (1992). The predominant rock types penetrated by the two boreholes are ash-flow and ash-fall tuffs. These tuffs are part of the Paintbrush Group and, in descending order, are the Tiva Canyon Tuff, Yucca Mountain Tuff, Pah Canyon Tuff, and upper $18 \mathrm{~m}$ of Topopah Spring Tuff. Layers of bedded and reworked tuff separate each of the four tuffs. The tuffs show various degrees of welding, ranging from nonwelded to densely welded.

UE-25 UZ\#16 borehole is located on the eastern side of the Yucca Mountain central block at the mouth of WT2 wash (fig. 2). Drilling of the borehole was started on May 27, 1992, and completed on March 11, 1993, to a total depth of $513.9 \mathrm{~m}$, penetrating about $15.2 \mathrm{~m}$ into the water table. The predominant rock types penetrated by the UE-25 UZ\#16 borehole are ash-flow and ash-fall tuffs. These tuffs are part of the Paintbrush Group and, in descending order, are the Tiva Canyon Tuff, Yucca Mountain Tuff, Pah Canyon Tuff, Topopah Spring Tuff, and the nonwelded tuffs that are interstratified with each of these tuffs, the Calico Hills Formation, and the Prow Pass Tuff. Details of the drilling of this borehole are given by Falah Thamir and others (U.S. Geological Survey, written commun., 1995).

The USW UZ-14 borehole is located in Drill Hole Wash, $26.2 \mathrm{~m}$ from USW UZ-1. Drilling of the borehole was started on April 15, 1993, cored to a depth of $672.6 \mathrm{~m}$ by April 29, 1994, and completed to a total depth of $677.8 \mathrm{~m}$ on May 6, 1994. Predominant rock types are similar to those of USW UZ-1 reported by Whitfield and others (1990). Details of the drilling on this borehole were also given by Falah Thamir and others (U.S. Geological Survey, written commun., 1995). 

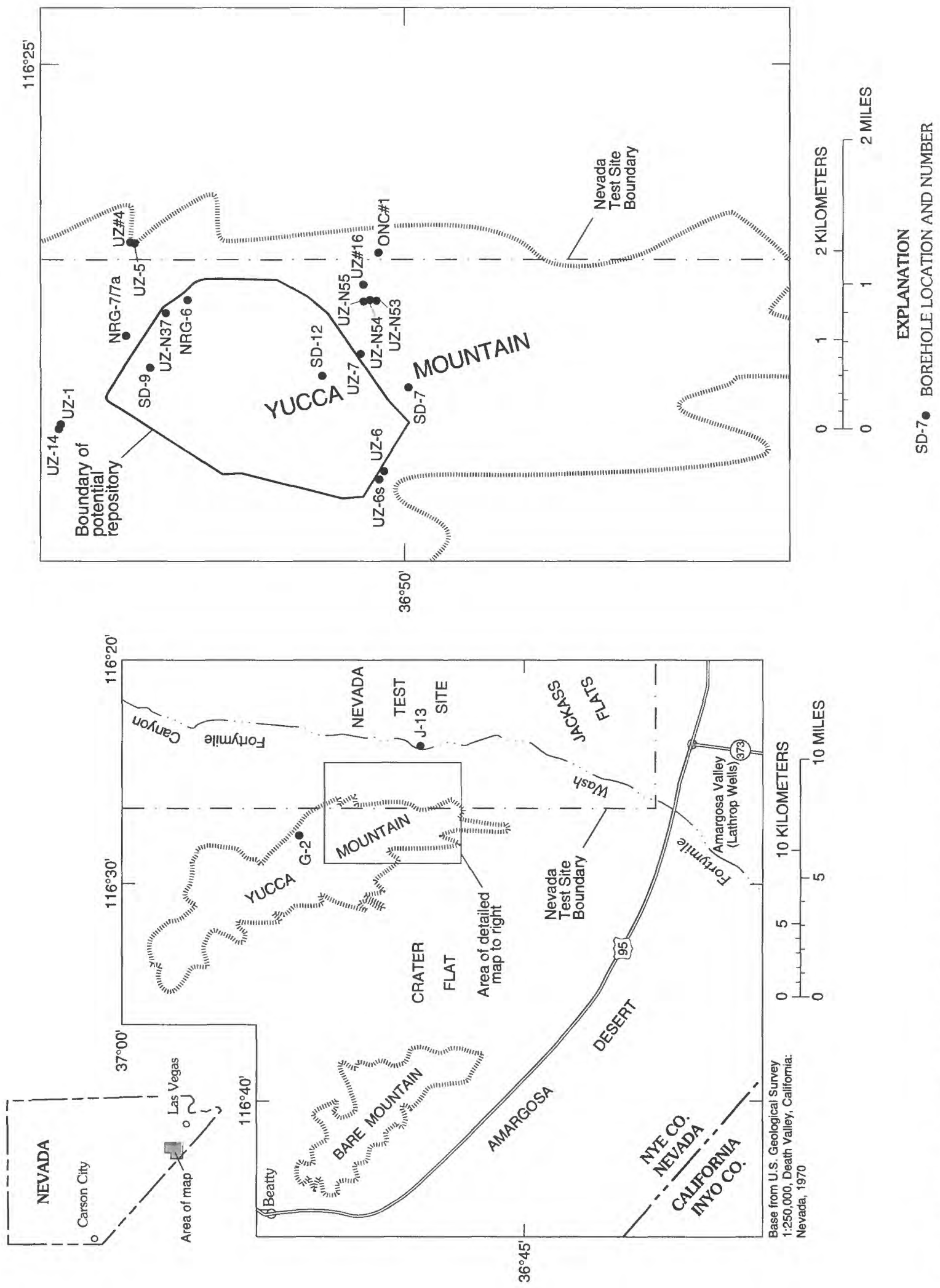

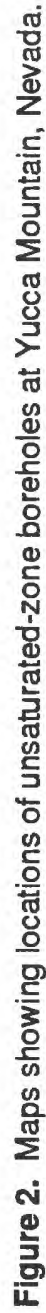


Other deep unsaturated-zone boreholes were drilled in addition to the UZ boreholes. North-ramp geologic boreholes NRG-6 and NRG-7a and systematic drilling geologic boreholes SD-7 and SD-9 have been completed (fig. 2). Drilling of NRG-6 was started on November 23, 1992, and cored to a total depth $335.3 \mathrm{~m}$ in the Topopah Spring Tuff on March 3, 1993. NRG-7a was drilled from October 21, 1993, and cored to a total depth of $461.3 \mathrm{~m}$ in the upper Calico Hills Formation on May 6, 1994. SD-9 was started on May 10, 1994, penetrating into the water table, and completed to a total depth of $677.6 \mathrm{~m}$ on September 26, 1994. SD-7 was started on October 3, 1994, and completed to a total depth of $497.4 \mathrm{~m}$ in the Calico Hills Formation on July 28, 1995.

\section{METHODS OF SAMPLE COLLECTION AND ANALYSIS}

Dry-drilling techniques were used to obtain all $\mathrm{UZ}$ cores from boreholes. The diameter of the rotary core was $6.10 \mathrm{~cm}$. Cores from the rock formation were obtained using a 1.52-m core barrel with a split inner tube. Core recovery was typically more than 90 percent. Three to four pieces of unfragmented solid core, approximately $15 \mathrm{~cm}$ long, were selected from most core runs for pore-water extraction. The remainder of the cores were selected for other hydrologic-property tests and for archiving.

\section{Aqueous-Phase Samples}

Sample-handling procedures affect the success of extracting uncontaminated water from core samples. Evaporation of pore water increases with sample exposure time in a dry climate, and strict precautions were taken to avoid loss of moisture or contamination of pore water in the cores (Striffler and Peters, 1993). Each core was wrapped in a thin plastic sheet, placed inside a lexan liner, and capped on both ends of the lexan liner. The lexan-contained core was then placed inside a thick aluminum foil bag and heat-sealed for moisture protection. The sealed cores were carefully packed into plastic coolers and transported from the drill site to the Sample Management Facility (SMF) at Jackass Flats, Nev., for log-in and storage. The storage temperature was kept at $6^{\circ}$ to $9^{\circ} \mathrm{C}$ until the cores were removed for pore-water extraction.

\section{Extraction of Pore Water from Core Samples}

Pore water was extracted from the cores by using a high-pressure one-dimensional (uniaxial) compression procedure (Mower and others, 1991, 1994; J.D. Higgins and others, Colorado School of Mines, written commun., 1995). Briefly, compression operations start with applying pressure to the first stress level of $103.4 \mathrm{MPa}$ at a rate of $69 \mathrm{kPa} / \mathrm{s}$. Loading continues in eight increments of $103.4 \mathrm{MPa}$ (at the same loading rate) until the final stress level of $827 \mathrm{MPa}$ is reached. Additional pore water can be extracted by injecting dry nitrogen gas (greater than 99.99 percent pure) into the pore space and by forcing out pore water at the end of compression. Water and gas samples are taken when adequate volumes are collected in the syringes. The extracted water was filtered through Nucleopore filters $(0.45 \mu \mathrm{m})$ into suitable bottles. Samples for major ions were stored in polyethylene bottles, and samples for stable isotopes and ${ }^{14} \mathrm{C}$ were stored in glass bottles.

The densely welded Topopah Spring Tuff, which generally has less than a 5-percent moisture content by weight, cannot yield water by compression. Therefore, the vacuum distillation method (Stewart, 1972; Walker and others, 1991) was used in this study. Cores which had undergone high-pressure compression were also distilled in a vacuum for the remaining water. That water can only be analyzed for ${ }^{3} \mathrm{H},{ }^{18} \mathrm{O}$, and ${ }^{2} \mathrm{H}$.

In vacuum distillation, water from cores is distilled by heat in a vacuum system and captured in a cold trap at $-78^{\circ} \mathrm{C}$. A temperature of $150^{\circ} \mathrm{C}$ was maintained at the heating mantle, resulting in a core temperature of about $110^{\circ} \mathrm{C}$. Vacuum-distilled water samples were stored in glass bottles for analysis of tritium. In samples with high zeolite contents (such as samples from the Calico Hills Formation), water may be fractionated and become more depleted in the heavy ${ }^{18} \mathrm{O}$ isotope when it reacts with zeolites in cavities or channels. Therefore, pore-water samples for stable isotopic analyses $\left(\delta \mathrm{D}\right.$ and $\left.\delta^{18} \mathrm{O}\right)$ should be processed by vacuum distillation on a nonzeolitic core sample, while compressed water which represents percolating water should be used for zeolite samples. Further investigations on the extent of isotopic fractionation by the zeolite minerals are in progress using isotope-tagged (known stable isotopic values) water imbibed into dry core from the Calico Hills Formation and the bedded tuff. 


\section{Collection of Perched and Saturated-Zone Water Samples}

Perched-water samples were collected from USW UZ-1, UZ-14, NRG-7a, SD-7, and SD-9. In addition, water samples were collected from the saturated zone immediately below the water table in $\mathrm{J}-13$, ONC\#1 (Office of Nye County), USW G-2, and UE-25 UZ\#16. All water samples were collected using plastic bailers or stainless-steel bailers. Samples were stored inside an ice cooler after collection and transferred to the SMF at the end of the day for longterm storage in a $6-9^{\circ} \mathrm{C}$ cold room. Water-quality parameters, such as $\mathrm{pH}$, specific conductance, and temperature (and occasionally bicarbonate concentration), were measured in the field laboratory. USW UZ-14 and USW SD-7 boreholes produced sufficient perched waters for hydraulic pumping tests. Consequently, only one complete set of perched-water samples was collected from each borehole except UZ-14 and SD-7, which were collected during pumping tests.

While drilling USW UZ-1 to a depth of $387.1 \mathrm{~m}$, a body of perched-water was penetrated. During a 495-minute period, $491 \mathrm{~L}$ of water was removed by bailing (Whitfield and others, 1990). One sample was collected on July 7, 1983, using a plastic bailer. The other water sample was collected on July 11, 1983, using the same bailer. Prior to initiation of drilling operations, the unsaturated section had been estimated to be about $470 \mathrm{~m}$ thick at the USW UZ-1 location. During the drilling of USW G-1 in 1980, located $305 \mathrm{~m}$ to the southeast of USW UZ-1, operational difficulties were experienced at a depth of $303.9 \mathrm{~m}$ (Spengler and others, 1981). At this point, a portion of the drill rods and several types of retrieval tools were lost into the borehole. The borehole was reamed to a larger diameter and cemented from 239.3 to $308.8 \mathrm{~m}$. The cement plug was then drilled through to a depth of $309.7 \mathrm{~m}$. A total of $9,250 \mathrm{~m}^{3}$ of drilling fluids was lost to the formation during reaming and cementing operations.

On July 30, 1993, wet cores from UZ-14 were observed from 383.0 to $383.6 \mathrm{~m}$ (Falah Thamir and others, U.S. Geological Survey, written commun., 1995). A fracture was observed at $383.7 \mathrm{~m}$. Core was dry below this fracture. A plastic bailer was left at the bottom of the borehole $(384.6 \mathrm{~m})$ over the weekend. On Monday morning (August 2, 1993), the bailer was full of water when it was pulled up. A whole set of hydrochemical samples was collected.
A supplemental set was collected on the same day using a plastic bailer. The third set was collected on August 2, 1993, using a stainless-steel bailer. About $20 \mathrm{~L}$ of water was collected. All water samples were stored in a refrigerator at the SMF.

On August 3, 1993, the borehole was drilled from 386.1 to $387.7 \mathrm{~m}$ and wet cores were recovered. A plastic bailer was lowered down the borehole and 17 bailers of water samples were collected. On August 4, 1993, the borehole was drilled from 387.7 to $389.2 \mathrm{~m}$ and cores were wet throughout. Coring continued from 389.2 to $390.8 \mathrm{~m}$. All cores were wet. Lithologically, the lower $1.3 \mathrm{~m}$ of this interval was composed of basal vitrophyre. On the morning of August 5, 1993, the water level was at $381.3 \mathrm{~m}$. Eight bailers of water samples were collected.

Hydraulic drawdown and recovery tests were conducted on August 17, 1993, to estimate the size of the perched-water body. A Moyno pump was placed at the bottom of the borehole, and pump tests were concluded on August 27, 1993. Four sets of hydrochemical samples were collected during the tests, and a final set of hydrochemical samples was collected on August 31, 1993.

Pumping tests for USW SD-7 were conducted for 1 week, from March 16 through 21, 1995, at a rate of $11 \mathrm{~L} / \mathrm{min}$. Perched-water samples for hydrochemical analysis were collected on March 8, 1995, when perched water at USW SD-7 was first reached, then collected twice a day during the pumping tests.

One sample of all other perched water (NRG-7A, SD-9) was collected from each borehole by using a plastic bailer.

\section{Analyses of Water Samples}

The tritium was analyzed at the UZ hydrochemistry laboratory in building 56 of the Denver Federal Center using procedures published by Thatcher and others (1977). Tritium values were calculated by regressing back to the date of sample collection so that tritium decay was considered between sample collection and dates of analysis. Tritium errors were approximately \pm 4 tritium units [ 1 tritium unit $(1 \mathrm{TU})=1{ }^{3} \mathrm{H}$ atom per $10^{18}{ }^{1} \mathrm{H}$ atoms]. Cation concentrations were measured using inductively coupled plasma emission spectroscopy, and anion concentrations were measured using ion chromatography at Huffman Laboratories, Inc., in Golden, Colo. Because only a small volume ( 3 to $30 \mathrm{~mL}$ ) of pore water was obtained for each sample, complete measurements of 
water composition were not possible for individual samples. The analytical error is \pm 5 percent for all major ions except sulfate, for which the error is \pm 10 percent. Charge balance is calculated by subtracting total milliequivalent anions from total milliequivalent cations divided by the total milliequivalents of cation and anion multiplied by 100 . However, silica concentration is not considered in the charge balance because of difficulty in assessing charge on silicate species. Analysis by Tandem Accelerator Mass Spectrometer (TAMS) for ${ }^{14} \mathrm{C}$ and $\delta^{13} \mathrm{C}$ required about 30 to $60 \mathrm{~mL}$ of water. Samples were sent to Beta Analytic, Inc., in Miami, Fla., for analyses. Bicarbonate in water was converted to carbonate and then precipitated as strontium carbonate. Carbonate samples were acidified to yield carbon dioxide and subsequently converted to graphite for determination by TAMS. Uncertainty in $\delta^{13} \mathrm{C}$ values was \pm 0.2 part per thousand (\%o), and for ${ }^{14} \mathrm{C}$ was \pm 0.7 percent modern carbon (pmc). Stable isotopes of oxygen and hydrogen were analyzed by mass spectrometer at the U.S. Geological Survey Research Laboratory in Reston, Va., and at the Stable Isotope Laboratory, Institute of Arctic and Alpine Research, University of Colorado, Boulder, Colo. Precision for the measurements was $\pm 0.2 \%$ for $\delta^{18} \mathrm{O}$ and $\pm 1.0 \%$ for $\delta \mathrm{D}$. All uncertainties quoted are one standard deviation.

\section{Gas Samples}

Gas samples were collected using a peristaltic pump connected through short silicone tubing to the downhole gas-sampling tubes. Gas-sampling tubes were pumped overnight before sample collection to purge the tubes of any atmospheric air that might have been introduced while connecting the pumps to the system. Generally, four types of gas samples were collected: gas composition, $\mathrm{CO}_{2}$ concentration, $\delta^{13} \mathrm{C}$, and ${ }^{14} \mathrm{C}$. Gas-sampling devices used were $500 \mathrm{~cm}^{3}$-per-minute peristaltic pumps connected through $0.95-\mathrm{cm}$-diameter Teflon tubes to the pumping ports.

\section{Collection from Borehole USW UZ-1}

Rock-gas samples were collected using a syringe inserted into a three-way stopcock in the gas-sampling line of borehole USW UZ-1 (fig. 3), which is permanently instrumented for gas sampling. Gas-sampling lines were pumped overnight (20 hours) before gas samples were taken. The syringe was flushed with sample gas at least three times before collection of a sample. Gas was then drawn into the syringe, the syringe was transported to the laboratory, and gas was injected into a gas chromatograph for composition analysis. Each probe was sampled daily during a gas-sampling trip-more frequently when abnormal gas compositions were observed.

Two gas-sampling methods were used for determination of $\delta^{13} \mathrm{C}$ ratio in carbon dioxide samples. In the first, the molecular-sieve (MS) method, the gas stream was initially passed continuously through a silica-gel tower to remove moisture (fig. 3), then through a $300-\mathrm{mL}$ stainless-steel cylinder containing a 50-nanometer (50-nm), anhydrous (dehydrated under a vacuum at $350^{\circ} \mathrm{C}$ ) molecular sieve to trap the $\mathrm{CO}_{2}$ gas. The 50-nm molecular sieve strongly traps $\mathrm{CO}_{2}$, which may be later recovered in the laboratory by heating to $350^{\circ} \mathrm{C}$ the stainless-steel cylinder (containing the molecular-sieve pellets) under a vacuum. This collection method was used from 1984 to 1991. In 1991, it was replaced by the whole-gas method described below.

The second method, the whole-gas (WG) method, was used for batch sampling. A gas stream was allowed to flow through a 500-mL glass container (or into a Mylar balloon) to purge the container several times before sampling (this "glass container" replaced the "gas sampler" in fig. 3). When the gas stream had attained a steady flow (indicated by flow meter), stopcocks at both ends were closed and the glass container removed from the flow line. The collection time was less than 5 minutes. This has become a preferred method and has been used continuously. Whole-gas samples collected in 500-mL glass containers are brought back to the laboratory for processing. About 99 percent of the gas collected is air. Separation of $\mathrm{CO}_{2}$ from air required a specially designed, W-shaped glass coil trap (fig. 4). The gas sample from the field collection was allowed to flow slowly through an $\mathrm{H}_{2} \mathrm{O}$ trap cooled with a dry-ice alcohol slurry to trap the water vapor, then through the W-shaped trap, cooled with liquid nitrogen to trap the $\mathrm{CO}_{2}$. Noncondensable gases exited through the vacuum pump. The process was completed in 5 hours for $3 \mathrm{~L}$ of gas and 3 hours for $500 \mathrm{~mL}$ of gas. 


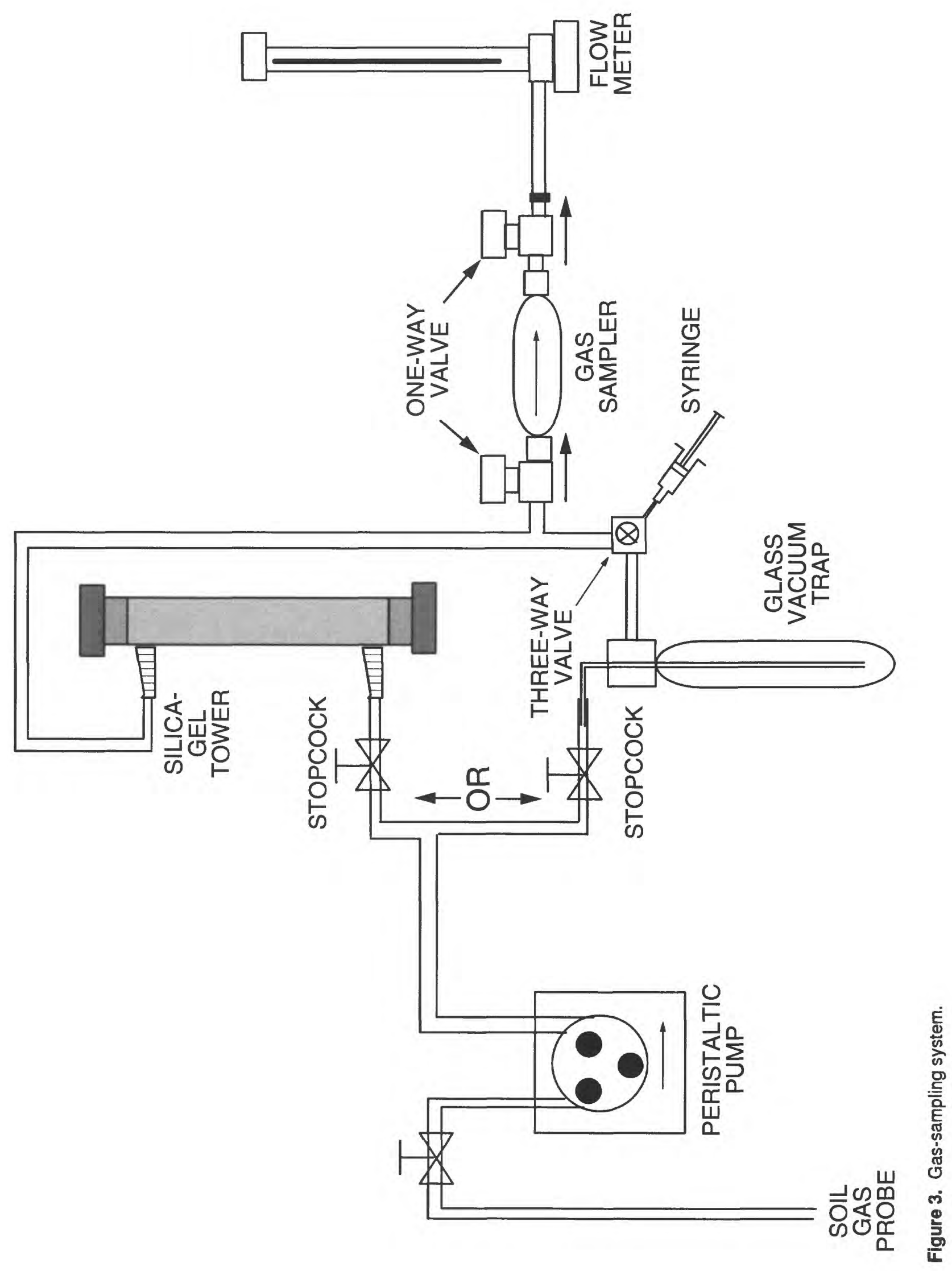




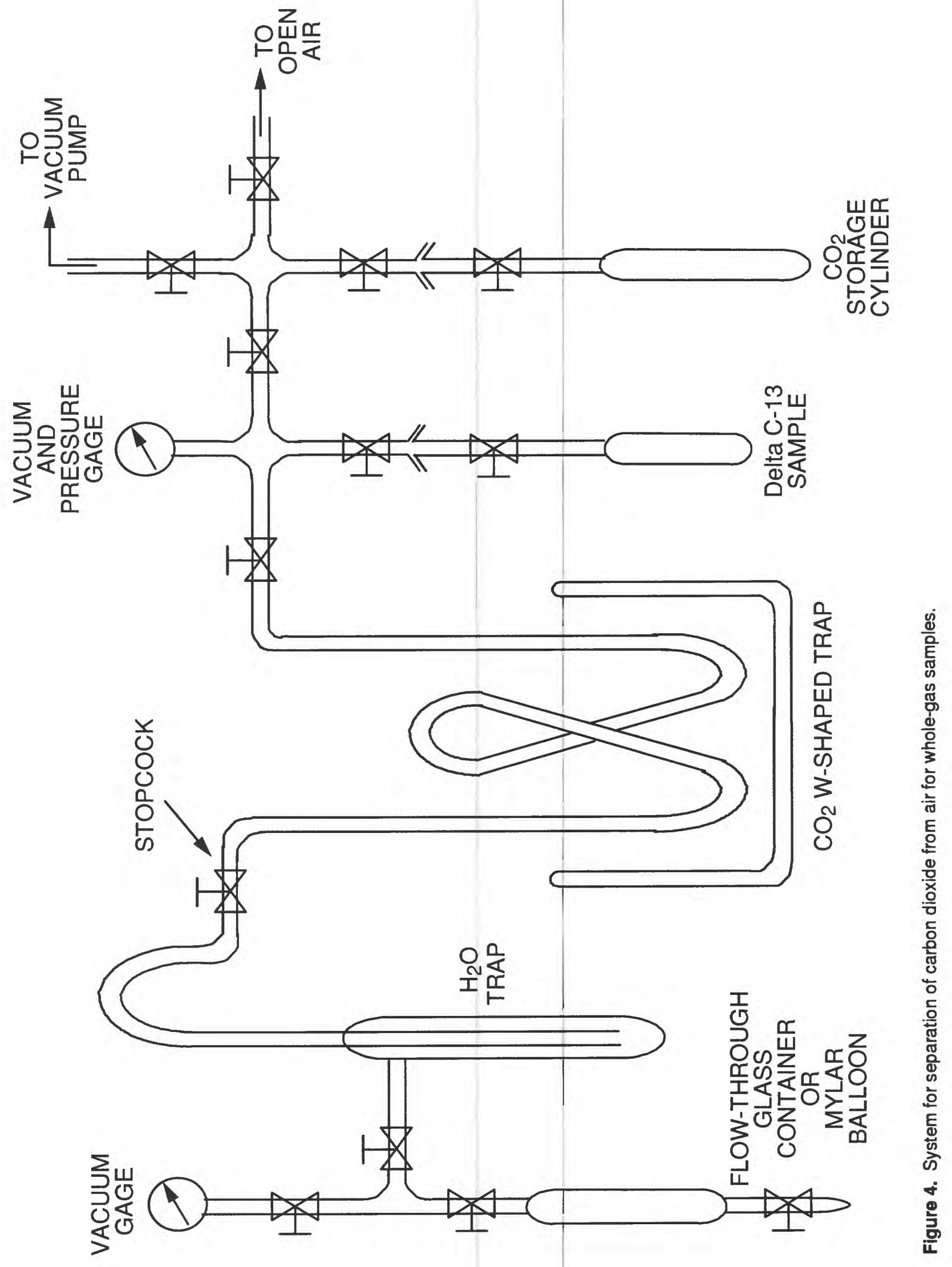


The method for ${ }^{14} \mathrm{C}$-sample collection was similar to the MS method used for $\delta^{13} \mathrm{C}$ samples except that the collection time is 5-10 days depending on the $\mathrm{CO}_{2}$ concentration of the gas. The $\mathrm{CO}_{2}$ gas trapped in the MS was degassed in the laboratory, and heated in the vacuum line system to $350^{\circ} \mathrm{C}$ to release the trapped $\mathrm{CO}_{2}$. Released carbon dioxide was collected in the cold trap, volume measured, and transferred to the storage cylinders. In the earliest stages of this study, some of the ${ }^{14} \mathrm{C}$ samples were collected by sorption in concentrated $\mathrm{KOH}$ solution as described in Haas and others (1983) and Yang and others (1985).

\section{Collection from Open Boreholes}

After a borehole was drilled, the atmospheric air that entered the formation during the drilling process was removed by evacuation from the surface with a large-capacity pump. The tracer $\left(\mathrm{SF}_{6}\right)$ concentration in the evacuated air was continuously monitored. Disappearance of the $\mathrm{SF}_{6}$ (concentration less than $0.1 \mathrm{ppm}$ ) assures the complete removal of the drilling air. Prototype tests for gas sampling from open boreholes was conducted by the U.S. Geological Survey near Superior, Ariz., in 1990, and results were reported by Peters and others (1991).

For UE-25 UZ\#4 and UZ\#5 boreholes, casing was retained inside the borehole for 6 years. Therefore, gas sampling was not conducted. Packers were installed inside the open boreholes in NRG-6, SD-12, and UZ\#16 for gas-sample collections. Two intervals were packed in NRG-6 (one at the Tiva Canyon Tuff and one at the Topopah Spring Tuff), five intervals were packed in UZ\#16 (one between the Tiva Canyon Tuff and Topopah Spring Tuff; two within the Topopah Spring Tuff, one between the Topopah Spring Tuff and Prow Pass Tuff, and one at the bottom of the borehole in the Prow Pass Tuff), and two intervals were packed in SD-12 (both within the Topopah Spring Tuff). In addition, a simple gassampling technique using clusters of nylon tubes hanging down the borehole at different depths was conducted at NRG-6, NRG-7a, and UZ\#16.

Gas-composition samples were collected using a syringe inserted into a three-way stopcock in the gas-sampling line in the same way as described above. Each probe was sampled daily during a gas-sampling trip, more frequently when abnormal $\mathrm{CO}_{2}$ concentrations were observed (usually rock-gas contains higher
$\mathrm{CO}_{2}$ concentration than atmospheric $\mathrm{CO}_{2}$, which is about 350 ppmv).

For the $\delta^{13} \mathrm{C}$ samples, a 3-L Mylar balloon was used to collect a rock-gas sample. A deflated balloon was connected to the outlet of the pump and inflated with the sample gas.

Carbon-14 samples were collected the same as for the instrumented borehole. The gas stream was initially passed continuously through a silica-gel tower to remove moisture (fig. 3 ), then through a $300-\mathrm{mL}$ stainless-steel cylinder containing a $50-\mathrm{nm}$, anhydrous (dehydrated under a vacuum at $350^{\circ} \mathrm{C}$ ) molecular sieve to trap the $\mathrm{CO}_{2}$ gas. The $50-\mathrm{nm}$ molecular sieve strongly traps $\mathrm{CO}_{2}$, which may be later recovered in the laboratory by heating the stainless-steel cylinder to $350^{\circ} \mathrm{C}$ (containing the molecular-sieve pellets) under a vacuum. The collection time is 5-10 days depending on the $\mathrm{CO}_{2}$ concentration of the gas.

\section{Analysis of Gas Samples}

Gas chromatography was used for composition analyses. Sulfur hexafluoride $\left(\mathrm{SF}_{6}\right)$ was measured using an electron-capture detector with pure nitrogen gas as a carrier gas. Carbon dioxide was measured using a flame-ionization detector and pure nitrogen gas as a carrier gas. Nitrogen $\left(\mathrm{N}_{2}\right)$, oxygen $\left(\mathrm{O}_{2}\right)$, and argon ( $\mathrm{Ar}$ ) were measured using a thermalconductivity detector and pure helium gas as a carrier gas. Nitrogen, oxygen, and argon were analyzed at a U.S. Geological Survey laboratory in Reston, Va. Analytical errors are about $\pm 0.004 \mathrm{ppm}$ for $\mathrm{SF}_{6}$ in a concentration range of 0.5 to $1.5 \mathrm{ppm}$, \pm 0.003 percent for $\mathrm{CO}_{2}$ in a concentration range of 0.01 to 0.10 percent by volume, 0.1 percent for $\mathrm{N}_{2}$ and $\mathrm{O}_{2}$, and \pm 0.02 percent for Ar at atmospheric concentrations.

Samples for $\delta^{13} \mathrm{C}$ were analyzed by mass spectrometry in the U.S. Geological Survey laboratory in Denver. The precision of $\delta^{13} \mathrm{C}$ analysis was about $\pm 0.2 \%$. Carbon- 14 samples were sent to Geochron Laboratories (Krueger Enterprises, Inc.), Cambridge, Mass., for ${ }^{14} \mathrm{C}$ determination by gas counting in a gas-proportional counter. Uncertainty in the ${ }^{14} \mathrm{C}$ measurement was \pm 0.7 pmc. Conventional ${ }^{14} \mathrm{C}$ determination (proportional counting, or liquid scintillation counting) requires about 1-2 $\mathrm{L}$ of pure $\mathrm{CO}_{2}$ gas at one atmosphere and $25^{\circ} \mathrm{C}$. Analysis by TAMS method requires only $10-20 \mathrm{~mL}$ of $\mathrm{CO}_{2}$ gas 
at the same pressure and temperature; however, the cost of analysis is twice as great by TAMS than by the conventional method. Only a few samples from $\mathrm{UZ}-1$ have been run by TAMS. Small ${ }^{14} \mathrm{C}$ samples were sent to the University of Arizona in Tucson for analysis by TAMS. Uncertainty in the ${ }^{14} \mathrm{C}$ measurement was \pm 1.5 pmc.

\section{INTERPRETATION OF CHEMICAL AND ISOTOPIC DATA}

Understanding the unsaturated-zone gas and water transport and flow mechanism at Yucca Mountain is essential to the site-characterization program. Chemical composition of pore water (which reflects the extent of water-rock interactions between the recharge water and the matrix rock), tritium, and ${ }^{14} \mathrm{C}$ ages, provide insight on the nature of flow mechanisms and residence times of the unsaturated-zone water. Carbon- 14 concentration measurement in the gaseous phase can provide information relevant to the residence time of $\mathrm{CO}_{2}$ in the unsaturated zone. Delta carbon-13 isotopic data can help to identify carbon sources, a necessary step in ${ }^{14} \mathrm{C}$ age estimation. Also, a depth profile of gas carbon isotopic data can provide information on gas-flow mechanisms through the unsaturated zone as well as interactions with aqueous phase and calcite mineral. From the present chemical and isotopic data, along with previously published USW UZ-1 data collected at Yucca Mountain (Yang and others, 1993), preliminary conceptual hydrologicflow models are described.

\section{Aqueous-Phase Data}

Samples for aqueous-phase chemical data can only be acquired from drill cores where water contents are greater than $7.7 \%$ by weight (Mower and others, 1994). The water contents of cores vary according to geologic unit and to degree of welding. As indicated in table 1 (Loskot and Hammermeister, 1992), the densely welded units sampled in UE-25 UZ\#4 and UZ\#5 have the smallest water contents, ranging from $2.4 \%$ to $6.4 \%$ (gram weight of $\mathrm{H}_{2} \mathrm{O}$ per gram of dry rock times 100) in the Tiva Canyon Tuff and ranging from $0.7 \%$ to $3.5 \%$ in the Topopah Spring Tuff. The nonwelded part of the Tiva Canyon Tuff had the largest water content of the nonwelded units sampled, with a maximum average water content of
$36.3 \%$ in borehole UZ\#4. Unnamed bedded tuff units generally have average water contents of about $16.7 \%$. The Calico Hills Formation in USW UZ-14 has average water content of about $17.5 \%$.

\section{Pore-Water Chemistry}

Water for chemical analyses was extracted from cores obtained from bedded tuff below the Pah Canyon Tuff in UE-25 UZ\#4 at depths ranging from about 91 to about $100 \mathrm{~m}$ and from cores obtained near the top of the Topopah Spring Tuff in UZ\#5 at depths ranging from about 103 to about $105 \mathrm{~m}$. These data have been published previously (Yang and others, 1988; Yang, 1992). All other UZ-hole and NRG-hole pore-water compositions were obtained from nonwelded tuffs, bedded tuff, or the Calico Hills Formation because of higher moisture content in these units. These data are presented in tables 2,3, and 4 for UE-25 UZ\#16, USW UZ-14, and USW NRG-6 and NRG-7a, respectively. Also, precipitation (rainwater) near the neutron-access boreholes (UE-25 UZN\#2) and ground water inside the neutronaccess boreholes (UE-25 UZN\#2 and USW UZN-46) were collected whenever water was detected at the bottom of the neutron-access boreholes (water was detected during the spring snowmelts or after the summer rainstorms). However, water inside the neutronaccess boreholes usually remained there only for a couple of days and then seeped into depth. Results of these chemical analyses are also presented in table 2 for references.

Chemical changes induced by compression appear to be minor, as evidenced from results of compression and centrifugation-extraction procedures (Yang and others, 1990). Peters and others (1992) reported pore-water chemistry changes under greater compression loads. Complete analyses of major- and trace-element concentrations on individual samples were not possible because of limited volumes of water $\left({ }^{14} \mathrm{C}\right.$ analysis requires about $70-80 \mathrm{~mL}$ of water for each sample); only major ions were selected for the chemical analyses.

A Piper diagram is a convenient graphical method for displaying the chemical composition of water. For example, in figure 5 it can be seen that major cations (sodium, calcium, and magnesium concentrations in percent milliequivalent) of one water sample are represented by one symbol in the lower left-hand side of the triangle, and major anions (chloride, sulfate, and bicarbonate plus carbonate in 
Table 1. Summary of relation of gravimetric water-content measurements of composite core to geologic unit and degre日 of welding for boreholes UE-25 UZ\#4 and UE-25 UZ\#5'1, Yucca Mountain, Nevada

[All water-content data in gram per gram; --,indicates no data]

\begin{tabular}{|c|c|c|c|c|c|}
\hline \multirow{3}{*}{$\begin{array}{l}\text { Lithoioglc } \\
\text { unit }\end{array}$} & \multicolumn{4}{|c|}{$\begin{array}{l}\text { Water content, } \\
\text { gram/gram }\end{array}$} & \multirow{3}{*}{$\begin{array}{c}\text { Degree of } \\
\text { weldling }\end{array}$} \\
\hline & \multicolumn{2}{|c|}{ UE-25 UZ\#4 } & \multicolumn{2}{|c|}{ UE-25 UZ\#5 } & \\
\hline & Data range & Average & Data range & Average & \\
\hline \multirow[t]{3}{*}{ Tiva Canyon } & $0.036-0.0642$ & 0.039 & $0.024-0.036$ & 0.030 & Densely welded \\
\hline & $0.061-0.063$ & 0.062 & -- & - & Moderately welded \\
\hline & $0.253-0.521$ & 0.363 & $0.145-0.290$ & 0.202 & Partly to nonwelded \\
\hline Yucca Mountain & $0.101-0.210$ & 0.157 & 0.0590 .143 & 0.110 & Partly to nonwelded \\
\hline Pah Canyon & $0.092-0.182$ & 0.134 & $0.084-0.221$ & 0.122 & Partly to nonwelded \\
\hline Bedded tuff & $0.069-0.391$ & 0.167 & $0.078-0.365$ & 0.176 & \\
\hline \multirow[t]{2}{*}{ Topopah Spring } & -- & -- & $0.221-0.279$ & 0.248 & Nonwelded \\
\hline & $0.007-0.035$ & 0.020 & $0.011-0.015$ & 0.013 & Densely welded \\
\hline
\end{tabular}

${ }^{1}$ From Loskot and Hammermeister (1992).

percent milliequivalent per liter) of the same sample are also represented by the same symbol in the lower right-hand side of the triangle. When these two major cation and anion locations are projected upward parallel to their respective grids, they intersect at one point in the upper diamond diagram and are represented by the same symbol for both major cation and anion compositions of that sample. The locations in the diamond diagram represent the type of water composition for each sample. Calcium chloride or sulfate type water formed from recharging water interacting with near-surface or shallow-depth soils will be located near the top part of the diamond. The ground water that has interacted with deep Calico Hills Formation rocks will result in sodium carbonatebicarbonate type water located near the lower part of the diamond. The middle part of the diamond will represent intermediate chemical compositions for ground water in the Topopah Spring Tuff. Dissolved solids in pore water expressed in parts per million are represented by the circle size with the scale shown in figure 5.

Figures 5,6A and 6B, and 7A and 7B are Piper

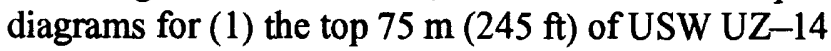
and saturated-zone chemical data; (2) USW NRG-6 and NRG-7a and lithologic contacts and adjacent beds; and (3) USW UZ-14 and UE-25 UZ\#16. Figure 5 shows saturated-zone water chemistry (Benson and McKinley, 1985) compared to the composition of unsaturated-zone pore water in the top $75 \mathrm{~m}$ of USW UZ-14, between the Tiva Canyon
Tuff and pre-Pah Canyon bedded tuff. It is evident from the plot that dissolved solids are, in most cases, significantly higher in the unsaturated-zone pore water than in the saturated-zone ground water except in some saturated-zone carbonate aquifers, where both are about the same. This comparison is based on saturated-zone chemical-composition data that were collected prior to implementation of the approved U.S. Geological Survey Yucca Mountain Project quality-assurance program and, therefore, the data are not qualified. Furthermore, pore water in the Tiva Canyon, bedded tuff, and Pah Canyon tuffs are all grouped near the top of the diamond in the Piper diagram (that is, calcium sulfate or chloride type water), whereas saturated-zone ground waters are grouped near the bottom of the diamond (that is, sodium bicarbonate or carbonate type water). The composition of pore water from NRG -6 and NRG-7a boreholes is given in figure 6A; pore-water composition of lithologic contacts and adjacent beds is given in table 5 and in figure 6B. In figure $6 \mathrm{~A}$, sample $\mathrm{G}$ represents core obtained from borehole NRG -6 at a depth of 256 feet. The location of this core is in the upper Topopah Spring Tuff and contains about 3,500 mg/L in dissolved solids. It is too deep in the borehole to be explained as a result of surface evaporation. Rather, such a large value of dissolved solids probably resulted from prolonged contact of percolating water with the less permeable silicate rocks without replacement by fresher, younger water. 
Table 2. Chemical composition of pore-water and ground-water samples from boreholes UE-25 UZ\#16, UE-25 UZ-N2, and UZ-N46, Yucca Mountain, Nevada

$\lceil\mu \mathrm{S} / \mathrm{cm}$, microsiemens per centimeter at 25 degrees Celsius; $\mathrm{mg} / \mathrm{L}$, milligrams per liter; - - -, data not available; 0 , values below detection limit; <, less than; *, contamination with sodium chloride during water-level measurement (accidentally dropped the measuring tape coated with sodium chloride); charge balance, (milliequivalent cation - milliequivalent anion)/(milliequivalent cation + milliequivalent anion) times 100]

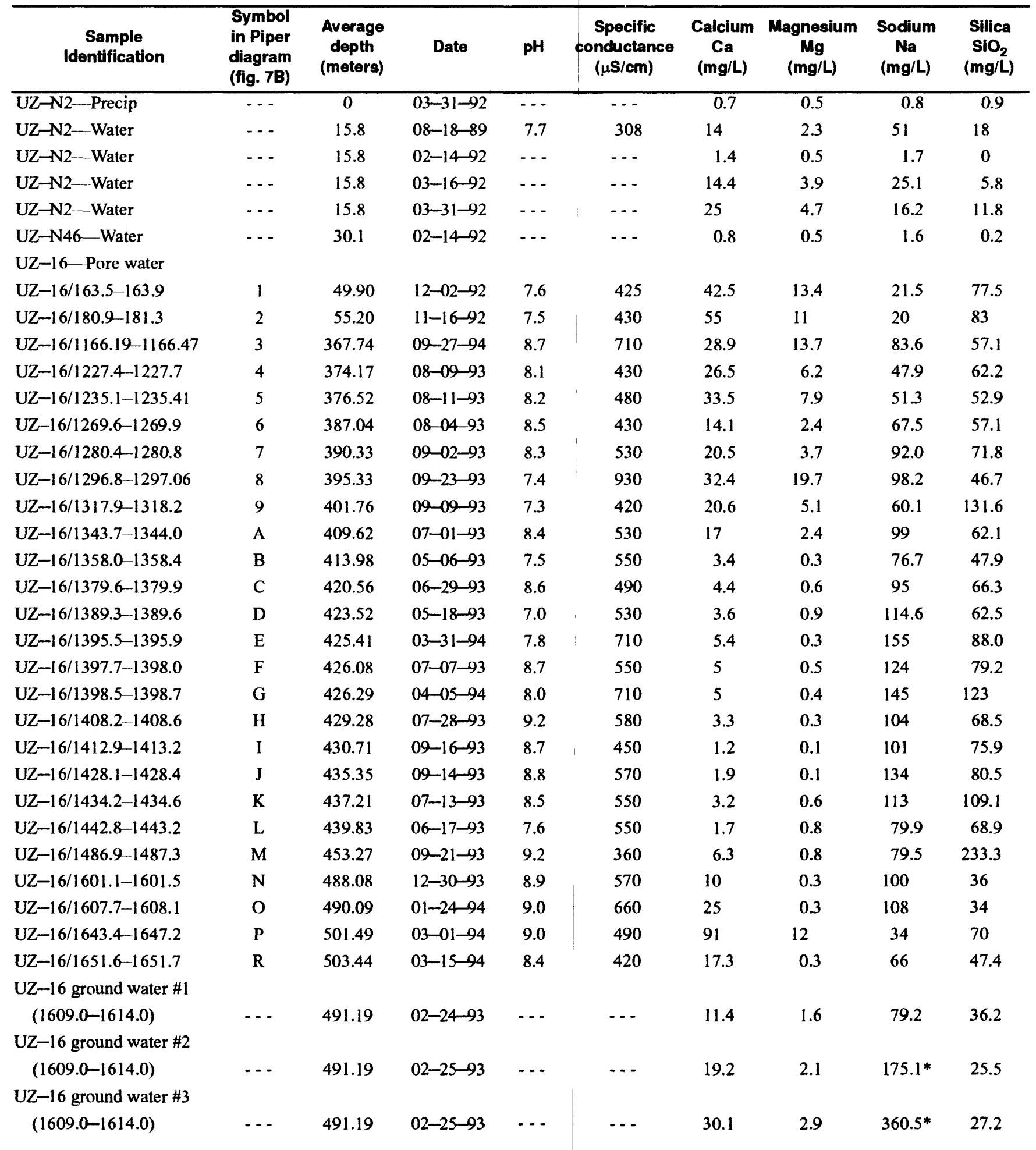


Table 2. Chemical composition of pore-water and ground-water samples from boreholes UE-25 UZ\#16, UE-25 UZ-N2, and UZ-N46, Yucca Mountain, Nevada-Continued

$[\mu \mathrm{S} / \mathrm{cm}$, microsiemens per centimeter at 25 degrees Celsius; $\mathrm{mg} / \mathrm{L}$, milligrams per liter; - - -, data not available; 0 , values below detection limit; <, less than; *, contamination with sodium chloride during water-level measurement (accidentally dropped the measuring tape coated with sodium chloride); charge balance, (milliequivalent cation - milliequivalent anion)/(milliequivalent cation + milliequivalent anion) times 100]

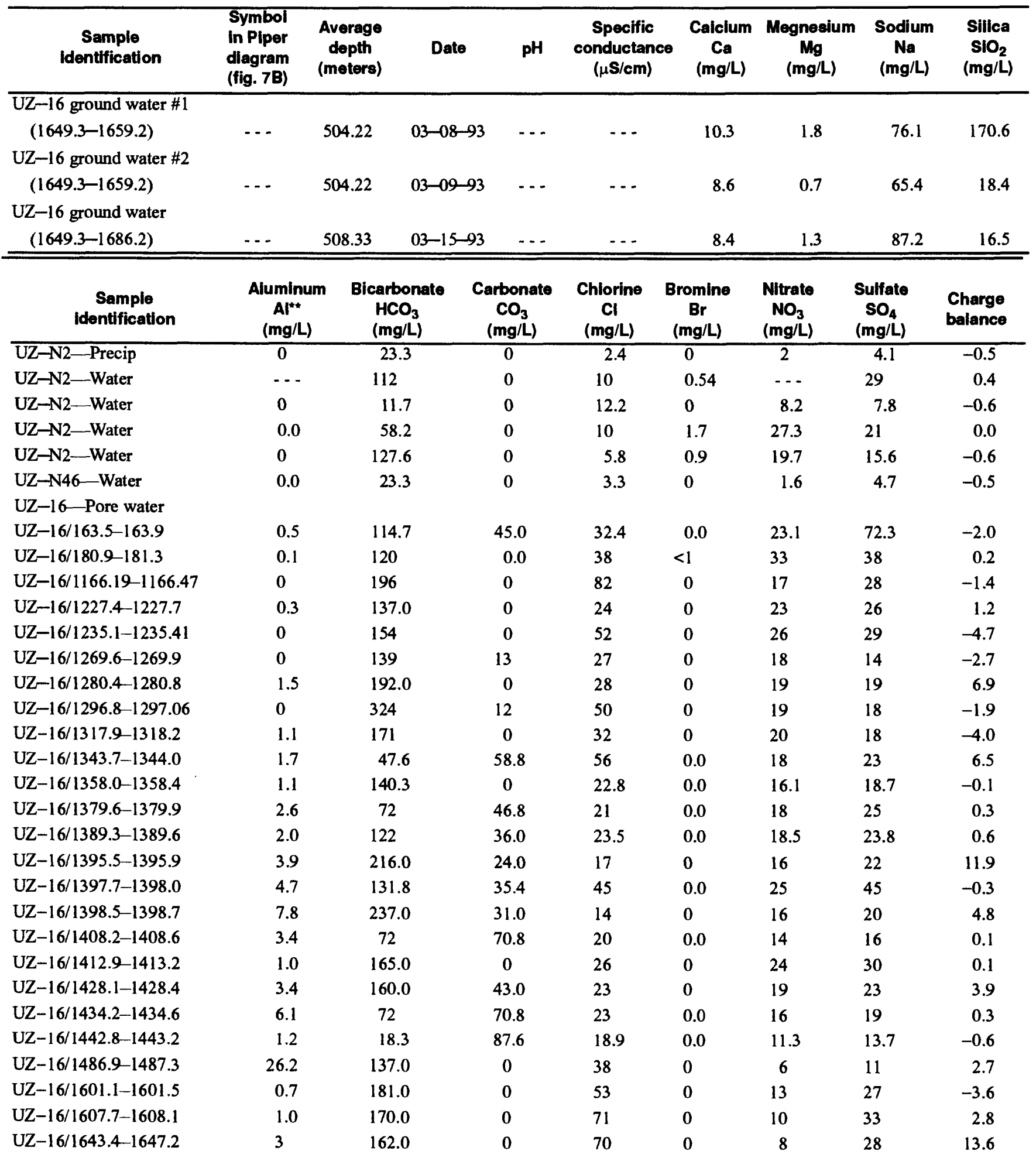


Table 2. Chemical composition of pore-water and ground-water samples from boreholes UE-25 UZ\#16, UE-25 UZ-N2, and UZ-N46, Yucca Mountain, Nevada-Continued

[ $\mu \mathrm{S} / \mathrm{cm}$, microsiemens per centimeter at 25 degrees Celsius; $\mathrm{mg} / \mathrm{L}$, milligrams per liter; - - -, data not available; 0 , values below detection limit; <, less than; *, contamination with sodium chloride during water-level measurement (accidentally dropped the measuring tape coated with sodium chloride); charge balance, (milliequivalent cation - milliequivalent anion)/(milliequivalent cation + milliequivalent anion) times 100]

\begin{tabular}{|c|c|c|c|c|c|c|c|c|}
\hline $\begin{array}{c}\text { Sample } \\
\text { Identification }\end{array}$ & $\begin{array}{c}\text { Aluminum } \\
\text { A })^{* *} \\
(\mathbf{m g} / \mathrm{L})\end{array}$ & $\begin{array}{c}\text { Bicarbonate } \\
\mathrm{HCO}_{3} \\
(\mathrm{mg} / \mathrm{L})\end{array}$ & $\begin{array}{c}\text { Carbonate } \\
\mathrm{CO}_{3} \\
(\mathrm{mg} / \mathrm{L})\end{array}$ & $\begin{array}{c}\text { Chlorine } \\
\text { Cl } \\
(\mathrm{mg} / \mathrm{L})\end{array}$ & $\begin{array}{c}\text { Bromine } \\
\text { Br } \\
(\mathrm{mg} / \mathrm{L})\end{array}$ & $\begin{array}{l}\text { Nitrate } \\
\mathrm{NO}_{3} \\
\text { (mg/L) }\end{array}$ & $\begin{array}{c}\text { Sulfate } \\
\mathrm{SO}_{4} \\
\text { (mg/L) }\end{array}$ & $\begin{array}{l}\text { Charge } \\
\text { balance }\end{array}$ \\
\hline $\mathrm{UZ}-16 / 1651.6-1651.7$ & 0.7 & 87.0 & 19.0 & 27 & 0 & 6 & 20 & 6.1 \\
\hline \multicolumn{9}{|l|}{ UZ-16 ground water $\# 1$} \\
\hline$(1609.0-1614.0)$ & 1.2 & 210.6 & 0 & 10.6 & 0.6 & 0.2 & 29.1 & -0.2 \\
\hline \multicolumn{9}{|l|}{ UZ-16 ground water \#2 } \\
\hline$(1609.0-1614.0)$ & 0 & 196.7 & $\mathbf{0}$ & $188.0^{*}$ & 0.6 & 0 & 31.8 & -0.4 \\
\hline \multicolumn{9}{|l|}{ UZ-16 ground water \#3 } \\
\hline$(1609.0-1614.0)$ & 0.2 & 200.0 & 0 & $488^{\star}$ & 0.7 & 0.5 & 34.6 & -0.3 \\
\hline \multicolumn{9}{|l|}{ UZ-16 ground water \#1 } \\
\hline$(1649.3-1659.2)$ & 19.9 & 164.2 & $\mathbf{0}$ & 13.4 & 0 & 0.3 & 27.7 & 0.3 \\
\hline \multicolumn{9}{|l|}{ UZ-16 ground water \#2 } \\
\hline$(1649.3-1659.2)$ & 0 & 151.6 & $\mathbf{0}$ & 10.6 & 0 & 0 & 25.5 & 0.0 \\
\hline \multicolumn{9}{|l|}{ UZ-16 ground water } \\
\hline$(1649.3-1686.2)$ & 0.1 & 197.3 & 0 & 8.6 & 1 & 0 & 27.7 & 0.3 \\
\hline
\end{tabular}

**0.45- $\mu \mathrm{m}$ filter paper was used; hence, particulate aluminum is likely included in these values.

Table 3. Chemical composition of pore-water samples from borehole USW UZ-14, Yucca Mountain, Nevada

$[\mu \mathrm{S} / \mathrm{cm}$, microsiemens per centimeter at 25 degrees Celsius; $\mathrm{mg} / \mathrm{L}$, milligrams per liter; - - -, data not available; 0 , values below detection limit; <, less than; N/S, not sampled; N/A, not analyzed; up1, uniaxial pressure stage \#1; charge balance, (milliequivalent cation - milliequivalent anion)/(milliequivalent cation + milliequivalent anion) times 100]

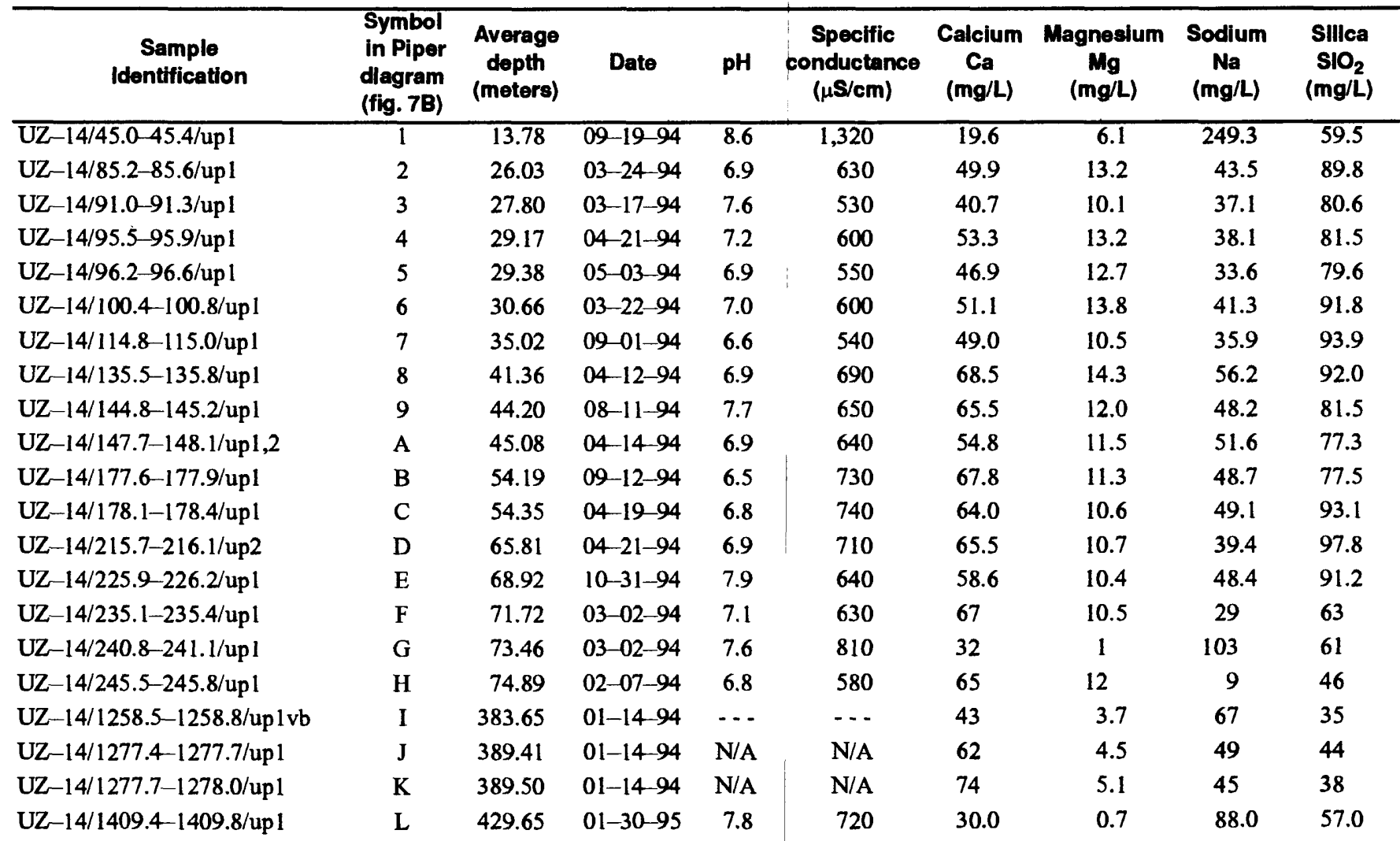


Table 3. Chemical composition of pore-water samples from borehole USW UZ-14, Yucca Mountain, Nevada—Continued

$\mid \mu \mathrm{S} / \mathrm{cm}$. microsiemens per centimeter at 25 degrees Celsius: $\mathrm{mg} / \mathrm{L}$, milligrams per liter; - - .. data not available: 0 , values below detection limit; <, less than; N/S, not sampled: N/A. not analyzed; up 1, uniaxial pressure stage \#1; charge balance, (milliequivalent cation - milliequivalent anion)/(milliequivalent cation + milliequivalent anion) times 1001

\begin{tabular}{|c|c|c|c|c|c|c|c|c|c|}
\hline $\begin{array}{c}\text { Sample } \\
\text { Identification }\end{array}$ & $\begin{array}{l}\text { Symbol } \\
\text { in Piper } \\
\text { diagram } \\
\text { (fig. } 7 B \text { ) }\end{array}$ & $\begin{array}{l}\text { Average } \\
\text { depth } \\
\text { (meters) }\end{array}$ & Date & $\mathbf{p H}$ & $\begin{array}{c}\text { Specific } \\
\text { conductance } \\
(\mu \mathrm{S} / \mathrm{cm})\end{array}$ & $\begin{array}{c}\text { Calcium } \\
\text { Ca } \\
(\mathrm{mg} / \mathrm{L})\end{array}$ & $\begin{array}{c}\text { Magnesium } \\
\mathbf{M g} \\
(\mathbf{m g} / \mathrm{L})\end{array}$ & $\begin{array}{c}\text { Sodium } \\
\mathbf{N a} \\
(\mathrm{mg} / \mathrm{L})\end{array}$ & $\begin{array}{c}\text { Sllica } \\
\mathrm{SIO}_{2} \\
(\mathbf{m g} / \mathrm{L})\end{array}$ \\
\hline$\overline{\mathrm{UZ}-14 / 1419.5-1419.8 / \text { upl }}$ & $\bar{M}$ & 432.72 & \multicolumn{2}{|c|}{$12-22-94$} & 410 & 20.0 & 0.6 & 68.0 & 60.0 \\
\hline UZ-14/1461.9-1462.1/upl & $\mathbf{N}$ & 445.62 & \multicolumn{2}{|c|}{$04-04-95$} & 570 & 9.2 & 0.1 & 128 & 68.7 \\
\hline UZ-14/1495.8-1496.0/up 1 & 0 & 455.95 & $04-11-95$ & 8.4 & 500 & 2.1 & 0.0 & 122 & 56.7 \\
\hline UZ-14/1524.55-1524.75/up 1 & $\mathbf{P}$ & 464.73 & $04-1495$ & 7.7 & 560 & 1.1 & 0.1 & 137 & 54.8 \\
\hline $\mathrm{UZ}-14 / 1542.3-1542.8 /$ up $1,2,3$ & $\mathbf{R}$ & 470.18 & $07-25-94$ & 8.6 & 760 & 3.6 & 0.5 & 207 & 143.0 \\
\hline $\mathrm{UZ}-14 / 1563.6-1563.8 /$ up $1,2,3$ & $\mathbf{S}$ & 476.62 & $08-30-94$ & 8.7 & 660 & 1.2 & 0.2 & 155.0 & 72.0 \\
\hline $\mathrm{UZ}-14 / 1564.6-1564.8 /$ up $1,2,3$ & $T$ & 476.92 & $08-23-94$ & 9.0 & 590 & 1.3 & 0.2 & 129 & 140.4 \\
\hline UZ-14/1564.9-1565.0/up I & $\mathbf{U}$ & 477.01 & $08-17-94$ & 8.3 & 690 & 1.7 & 0.5 & 169.0 & 54.0 \\
\hline$U Z-14 / 1585.0-1585.2 /$ up 1 & V & 483.14 & $09-14-94$ & 8.9 & 460 & 0.9 & 0.3 & 106.8 & 74.5 \\
\hline$U Z-14 / 1585.3-1585.6 /$ up 1,5 & W & 483.23 & $10-03-94$ & 9.3 & 400 & 1.2 & 0.5 & 85.0 & 75.0 \\
\hline UZ-14/1605.9-1606.1/up 1 & $\mathrm{X}$ & 489.51 & $10-07$ & 8.9 & 470 & 1.0 & 0.3 & 87.8 & 67.2 \\
\hline UZ-14/1644.3-1644.5/up I & $\mathbf{Y}$ & 501.21 & $01-19$ & 8.8 & 420 & 2.2 & 0.7 & 110.0 & 74 \\
\hline$U Z-14 / 1674.8-1675.1 /$ up I & Z & 510.54 & $10-24$ & 7.2 & $\mathrm{~N} / \mathrm{S}$ & 1.8 & 0.6 & 58.0 & 64.6 \\
\hline UZ-14/1695.4-1695.6/up I & $\$$ & 516.79 & $12-29$ & 7.9 & N/A & 1.4 & 1.1 & 115.8 & 55.9 \\
\hline UZ-14/1715.0-1715.3/upl & $\&$ & 522.79 & $03-28$ & 7.3 & 390 & 0.2 & 0.0 & 88 & 52.9 \\
\hline$U Z-14 / 1734.5-1734.7 /$ up 1 & $*$ & 528.71 & $05-02$ & 8.7 & 750 & 2.0 & 0.3 & 184 & 50.7 \\
\hline UZ-14/2104.05/well bottom & + & 641.33 & $04-22$ & 9.4 & $\ldots$ & 2.1 & 0.7 & 143 & 352 \\
\hline $\begin{array}{c}\text { Sample } \\
\text { Identification }\end{array}$ & $\begin{array}{c}\text { Aluminu } \\
\qquad \mathbf{A l}^{*} \\
(\mathrm{mg} / \mathrm{L})\end{array}$ & $\begin{array}{r}\text { Bicar } \\
\text { He } \\
\text { (m }\end{array}$ & $\begin{array}{l}\text { conate } \\
\mathrm{O}_{3} \\
\mathrm{~g} / \mathrm{L})\end{array}$ & $\begin{array}{c}\text { Carbonate } \\
\mathrm{CO}_{3} \\
(\mathrm{mg} / \mathrm{L})\end{array}$ & $\begin{array}{c}\text { Chlorine } \\
\text { Cl } \\
\text { (mg/L) }\end{array}$ & $\begin{array}{c}\text { Bromine } \\
\text { Br } \\
\text { (mg/L) }\end{array}$ & $\begin{array}{c}\text { Nitrate } \\
\mathrm{NO}_{3} \\
\text { (mg/L) }\end{array}$ & $\begin{array}{c}\text { Sulfate } \\
\mathrm{SO}_{4} \\
(\mathrm{mg} / \mathrm{L})\end{array}$ & $\begin{array}{l}\text { Charge } \\
\text { balance }\end{array}$ \\
\hline$\overline{\mathrm{UZ}-14 / 45.0-45.4 / \mathrm{upI}}$ & 1 & 2 & & 18 & 245 & 0 & $\overline{35}$ & 33 & -1.8 \\
\hline UZ--14/85.2-85.6/upl & 0.3 & 1. & & $\mathbf{0}$ & 60 & $\mathbf{0}$ & 22 & 66 & -0.9 \\
\hline $\mathrm{UZ}-14 / 91.0-91.3 / \mathrm{upl}$ & 0.0 & & 7 & $\mathbf{0}$ & 47 & 0 & 26 & 81 & -4.1 \\
\hline UZ-14/95.5-95.9/upl & 0 & & 3 & 0 & 79 & 0 & 29 & 83 & -1.9 \\
\hline UZ-14/96.2-96.6/upl & 0 & & 9 & $\mathbf{0}$ & 59 & 0 & 26 & 75 & -0.9 \\
\hline$U Z-14 / 100.4-100.8 /$ upl & 0.0 & 1 & & 0 & 44 & 0 & 23 & 83 & 0.5 \\
\hline $\mathrm{UZ}-14 / 114.8-115.0 /$ up 1 & $\mathbf{0}$ & & 7 & $\mathbf{0}$ & 61 & 0 & 25 & 90 & -2.1 \\
\hline UZ-14/135.5-135.8/upl & 0 & 10 & & $\mathbf{0}$ & 83 & 0 & 23 & 96 & 4.6 \\
\hline $\mathrm{UZ}-14 / 144.8-145.2 / \mathrm{up} 1$ & 0 & 1 & & 0 & 77 & 0 & 22 & 102 & -1.7 \\
\hline $\mathrm{UZ}-14 / 147.7-148.1 /$ up 1,2 & 0 & & 9 & 0 & 83 & 0 & 22 & 102 & -1.5 \\
\hline UZ-14/177.6-177.9/up I & $\mathbf{0}$ & & 9 & 0 & 100 & $\mathbf{0}$ & 23 & 130 & -2.0 \\
\hline UZ-14/178.1-178.4/upl & 0 & & 2 & 0 & 97 & 0 & 21 & 120 & -3.0 \\
\hline UZ-14/215.7-216.1/up2 & $\mathbf{0}$ & & 5 & 0 & 85 & 0 & 14 & 130 & -3.0 \\
\hline UZ-14/225.9-226.2/upl & 0 & & 5 & $\mathbf{0}$ & 93 & 0 & 16 & 116 & -2.6 \\
\hline UZ-14/235.1-235.4/upl & 0.0 & & 6 & $\mathrm{~N} / \mathrm{S}$ & 84 & 0 & 15 & 94 & -5.7 \\
\hline UZ-14/240.8-241.1/up 1 & 3 & & & $\mathrm{~N} / \mathrm{S}$ & 99 & 0 & 17 & 100 & -11.7 \\
\hline $\mathrm{UZ}-14 / 245.5-245.8 /$ up I & 0 & & 6 & $\mathrm{~N} / \mathrm{S}$ & 77 & 0 & 12 & 79 & -4.7 \\
\hline $\mathrm{UZ}-14 / 1258.5-1258.8 / \mathrm{uplvb}$ & 0.0 & 1 & & $\mathrm{~N} / \mathrm{S}$ & 88 & $\mathbf{0}$ & 16 & 19 & -4.9 \\
\hline UZ-14/1277.4-1277.7/upl & 0.0 & & & $\mathrm{~N} / \mathrm{S}$ & 87 & 0 & 17 & 45 & -7.1 \\
\hline UZ-14/1277.7-1278.0/up 1 & 0.0 & 1 & & N/S & 130 & 0 & 15 & 38 & -10.3 \\
\hline UZ-14/1409.4-1409.8/upl & 0.1 & 1 & & 0 & 75 & 0.0 & 5 & 106 & -13.2 \\
\hline UZ-14/1419.5-1419.8/upl & 1.4 & 1 & & 0 & 24 & 0.0 & 6 & 21 & 1.0 \\
\hline $\mathrm{UZ}-14 / 1461.9-1462.1 /$ up 1 & 1.2 & 2 & & 0 & 24.2 & 0 & 6.2 & 37.3 & 1.1 \\
\hline UZ-14/1495.8-1496.0/up1 & 0.3 & 2 & & 0 & 28.0 & 0 & 10.8 & 14.3 & 3.9 \\
\hline
\end{tabular}


Table 3. Chemical composition of pore-water samples from borehole USW UZ-14, Yucca Mountain, Nevada—Continued

$[\mu \mathrm{S} / \mathrm{cm}$, microsiemens per centimeter at 25 degrees Celsius; $\mathrm{mg} / \mathrm{L}$, milligrams per liter; - . - , data not available; 0 , values below detection limit; <, less than; N/S, not sampled; N/A, not analyzed; up1, uniaxial pressure stage \#1; charge balance, (milliequivalent cation - milliequivalent anion)/(milliequivalent cation + milliequivalent anion) times 100$]$

\begin{tabular}{|c|c|c|c|c|c|c|c|c|}
\hline $\begin{array}{c}\text { Sample } \\
\text { Identfication }\end{array}$ & $\underset{\substack{\mathbf{A i}^{*} \\
(\mathbf{m g} / L)}}{\text { Aluminum }}$ & $\begin{array}{c}\text { Bicarbonate } \\
\mathrm{HCO}_{3} \\
\text { (mg/L) }\end{array}$ & $\begin{array}{c}\text { Carbonate } \\
\mathrm{CO}_{3} \\
(\mathrm{mg} / \mathrm{L})\end{array}$ & $\begin{array}{c}\text { Chlorine } \\
\text { Cl } \\
(\mathrm{mg} / \mathrm{L})\end{array}$ & $\begin{array}{c}\text { Bromine } \\
\text { Br } \\
(\mathrm{mg} / \mathrm{L})\end{array}$ & $\begin{array}{l}\text { Nitrate } \\
\mathrm{NO}_{3} \\
\text { (mg/L) }\end{array}$ & $\begin{array}{c}\text { Suifate } \\
\mathrm{sO}_{4} \\
(\mathrm{mg} / \mathrm{L})\end{array}$ & $\begin{array}{l}\text { Charge } \\
\text { balance }\end{array}$ \\
\hline$\overline{\mathrm{UZ}-14 / 1524.55-1524.75 / \text { up1 }}$ & 1.1 & 232 & $\overline{0}$ & 26.2 & $\overline{0}$ & 12.5 & $\overline{22.3}$ & $\overline{7.2}$ \\
\hline UZ-14/1542.3-1542.8/up $1,2,3$ & 13.8 & 384 & 46 & 20 & 0 & 4 & 28 & 1.0 \\
\hline UZ-14/1563.6-1563.8/up $1,2,3$ & 13.9 & 160 & 97 & 16 & 0.0 & 4 & 14 & 1.2 \\
\hline UZ-14/1564.6-1564.8/up $1,2,3$ & 9.4 & 61 & 113 & 16 & 0 & 4 & 17 & 0.4 \\
\hline UZ-14/1564.9-1565.0/up 1 & 15.5 & 376 & 0 & 23 & 0.0 & 1 & 30 & 0.1 \\
\hline UZ-14/1585.0-1585.2/up 1 & 5 & 98 & 67 & 14 & 0 & 7 & 10 & 1.6 \\
\hline UZ-14/1585.3-1585.6/up 1,5 & 16.3 & 148 & 18 & 11 & 0.0 & 6 & 9 & 2.4 \\
\hline UZ-14/1605.9-1606.1/up 1 & 6 & 178 & 0 & 18 & 0 & 6 & 9 & 2.4 \\
\hline UZ-14/1644.3-1644.5/up 1 & 30.9 & 74.0 & 79 & 14 & 0.0 & 0 & 9 & 5.5 \\
\hline UZ-14/1674.8-1675.1/up 1 & 18 & 104 & 0 & 10 & 0 & 4 & 9 & 8.6 \\
\hline UZ-14/1695.4-1695.6/upl & 10 & 203 & 18 & 21 & 0 & 5 & 26 & 0.6 \\
\hline UZ-14/1715.0-1715.3/up 1 & 0.6 & 168 & 0 & 11.9 & 0 & 3.1 & 16.0 & 5.1 \\
\hline UZ-14/1734.5-1734.7/up 1 & 0.1 & 211 & 79 & 39.4 & 0 & 5.6 & 17.5 & 2.9 \\
\hline UZ-14/2104.05/well bottom & 38 & 229 & 19 & 10 & 0 & 4 & 23 & 10.1 \\
\hline
\end{tabular}

*0.45- $\mu \mathrm{m}$ filter paper was used; hence, particulate aluminum is likely included in these values.

Table 4. Chemical composition of pore-water and ground-water samples from borehole NRG-6/7a, Yucca Mountain, Nevada $[\mu \mathrm{S} / \mathrm{cm}$, microsiemens per centimeter at 25 degrees Celsius; $\mathrm{mg} / \mathrm{L}$, milligrams per liter; - - - -, data not available; 0 , values below detection limit; upl, uniaxial pressure stage \#1; charge balance, (milliequivalent cation - milliequivalent anion)/(milliequivalent cation + milliequivalent anion) times 100]

\begin{tabular}{|c|c|c|c|c|c|c|c|c|}
\hline $\begin{array}{c}\text { Sample } \\
\text { Identification }\end{array}$ & $\begin{array}{l}\text { Symbol } \\
\text { in Plper } \\
\text { diagram } \\
\text { (fig. 7B) }\end{array}$ & $\begin{array}{l}\text { Averege } \\
\text { depth } \\
\text { (meters) }\end{array}$ & Date & co & $\begin{array}{l}\text { Speclfic } \\
\text { conductance } \\
\text { ( } \mathrm{SS} / \mathrm{cm})\end{array}$ & $\begin{array}{c}\text { Calclum } \\
\text { Ca } \\
\text { (mg/L) }\end{array}$ & $\begin{array}{c}\text { Magneslum } \\
\text { Mg } \\
\text { (mg/L) }\end{array}$ & $\begin{array}{c}\text { Sodlum } \\
\mathrm{Na} \\
\text { (mg/L) }\end{array}$ \\
\hline$\overline{\text { NRG-6/158.2-158.6/up1 }}$ & $\bar{A}$ & 48.28 & $07-06-94$ & $\overline{6.4}$ & 1070 & 122 & 23.3 & 35.6 \\
\hline NRG-6/160.8-161.2/up 1 & B & 49.07 & $01-17-95$ & 7.0 & 860 & 104 & 18 & 35.0 \\
\hline NRG-6/171.0-171.3/up1 & $\mathrm{C}$ & 52.18 & $07-21-94$ & 7.0 & 620 & 70.5 & 11.5 & 29.2 \\
\hline NRG-6/175.6-176.0/up1 & D & 53.58 & $08-01-94$ & 6.6 & 520 & 49.2 & 8.6 & 29.4 \\
\hline NRG-6/219.9-220.2/up1 & E & 67.09 & $11-30-94$ & 7.0 & 660 & 24.3 & 4.2 & 99.3 \\
\hline NRG-6/244.6-245.0/up1 & F & 74.62 & $01-10-95$ & 6.6 & 630 & 33 & 4.9 & 72.0 \\
\hline NRG-6/255.9-256.1/up1 & G & 78.03 & $01-12-95$ & 6.7 & 1920 & 176 & 19 & 215.0 \\
\hline NRG-7a/1492.7-1493.1/up 1 & $\mathbf{H}$ & 455.04 & $05-26-94$ & - & $-\ldots$ & 30.6 & 0.3 & 74.7 \\
\hline NRG-7/1498.6-1498.9/up1 & I & 456.83 & $06-28-94$ & 7.5 & 500 & 28.7 & 0.5 & 73.2 \\
\hline $\begin{array}{c}\text { Sample } \\
\text { Identlfication }\end{array}$ & $\begin{array}{c}\text { Silica } \\
\mathrm{SiO}_{2} \\
(\mathrm{mg} / \mathrm{L})\end{array}$ & 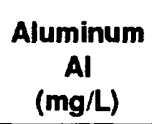 & $\begin{array}{c}\text { Bicarbonate } \\
\mathrm{HCO}_{3} \\
\text { (mg/L) }\end{array}$ & $\begin{array}{c}\text { Carbonate } \\
\mathrm{CO}_{3} \\
\text { (mg/L) }\end{array}$ & $\begin{array}{c}\text { Chlorine } \\
\text { Cl } \\
\text { (mg/L) }\end{array}$ & $\begin{array}{c}\text { Bromine } \\
\text { Br } \\
(\mathrm{mg} / \mathrm{L})\end{array}$ & $\begin{array}{c}\text { Nitrate } \\
\mathrm{NO}_{3} \\
\text { (mg/L) }\end{array}$ & $\begin{array}{c}\text { Sulfate } \\
\mathrm{SO}_{4} \\
(\mathrm{mg} / \mathrm{L})\end{array}$ \\
\hline NRG-6/158.2-158.6/up1 & 97.4 & 0 & 34 & 0 & 185 & 1 & 32 & 159 \\
\hline NRG-6/160.8-161.2/up1 & 84.0 & 1.6 & 55 & 0 & 148 & 0.9 & 35 & 139 \\
\hline NRG-6/171.0-171.3/up 1 & 79.4 & $\mathbf{0}$ & 48 & 13 & 58 & 0 & 43 & 94 \\
\hline NRG-6/175.6-176.0/up1 & 78.1 & 0 & 60 & 0 & 47 & 0 & 42 & 64 \\
\hline NRG-6/219.9-220.2/up1 & 61.4 & 1 & 92 & 0 & 77 & 0 & 47 & 77 \\
\hline NRG-6/244.6-245.0/up 1 & 51.0 & 0.6 & 61 & 0 & 49 & 0.1 & 40 & 115 \\
\hline NRG-6/255.9-256.1/up 1 & 68.0 & 0.9 & 61 & 0 & 115 & 0.0 & 35 & 840 \\
\hline NRG-7a/1492.7-1493.1/up1 & 71.5 & 0.0 & 104 & 34 & 39 & 0 & 18 & 23 \\
\hline NRG-7/1498.6-1498.9/upl & 83.0 & 1 & 156 & 0 & 50 & 0 & 17 & 18 \\
\hline
\end{tabular}




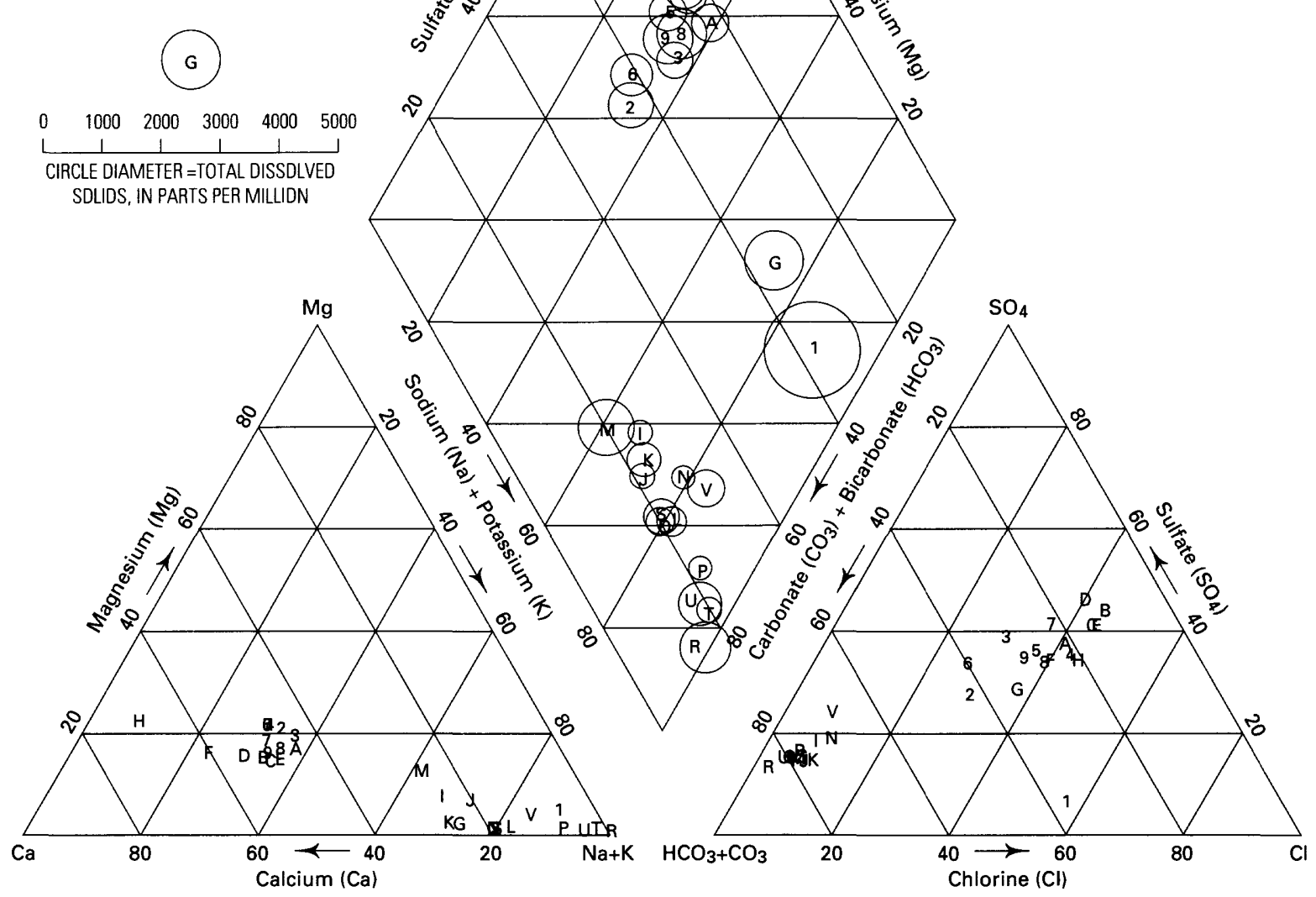

PERCENTAGE OF MILLIEOUIVALENTS PER LITER

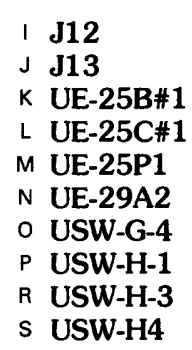

EXPLANATION

$\begin{array}{ll}T & \text { USW-H5 } \\ U & \text { USW-H6 } \\ \checkmark & \text { USW-VH-1 } \\ 1 & \text { UZ-14 (45.2 feet) } \\ 2 & \text { UZ-14 (85.4 feet) } \\ 3 & \text { UZ-14 (91.2 feet) } \\ 4 & \text { UZ-14 (95.7 feet) } \\ 5 & \text { UZ-14 (96.4 feet) } \\ 6 & \text { UZ-14 (100.6 feet) } \\ 7 & \text { UZ-14 (114.9 feet) }\end{array}$

8 UZ-14 (135.7 feet)

9 UZ-14 (145.0 feet)

A UZ-14 (147.9 feet)

B UZ-14 (177.8 feet)

C UZ-14 (178.3 feet)

D UZ-14 (215.9 feet)

E UZ-14 (226.0 feet)

F UZ-14 (235.3 feet)

G UZ-14 (241.0 feet)

H UZ-14 (245.7 feet)

Figure 5. Piper diagram showing top 75 meters of USW UZ-14 pore water $(1-9$, and $A-H)$ and saturated-zone water compositions (I-V). 


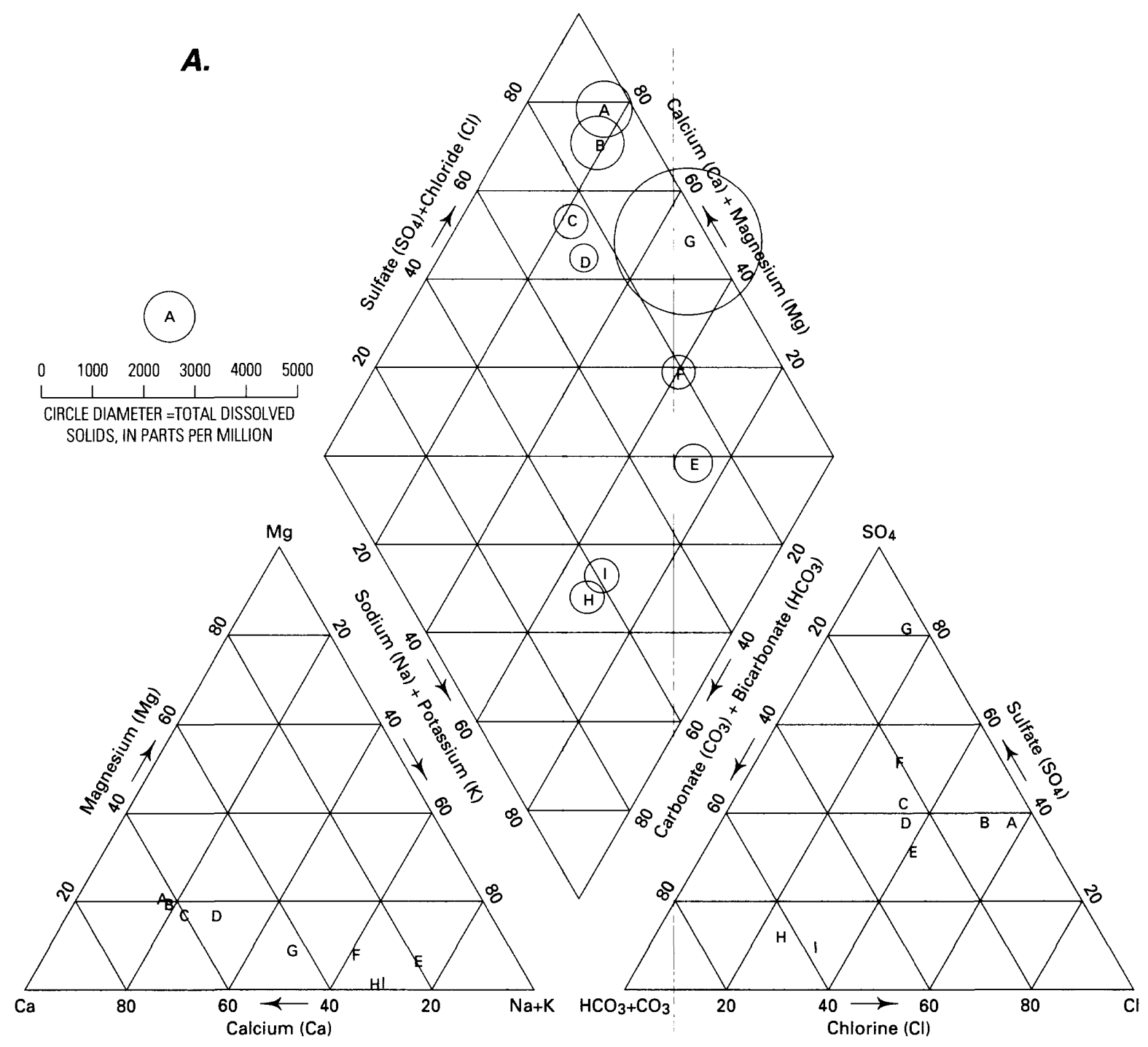

PERCENTAGE OF MILLIEQUIVALENTS PER LITER

EXPLANATION

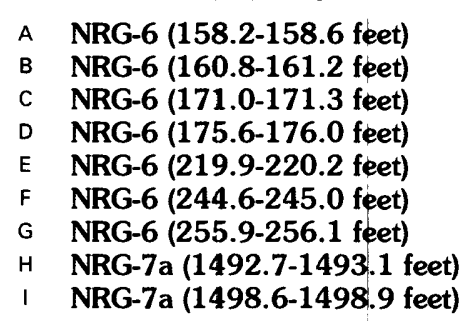

Flgure 6. Piper diagram showing (A) USW NRG-6 and 7a pore-water composition, and (B) composition of lithologic contacts and adjacent beds from USW NRG-6,7a, and unsaturated-zone boreholes. 


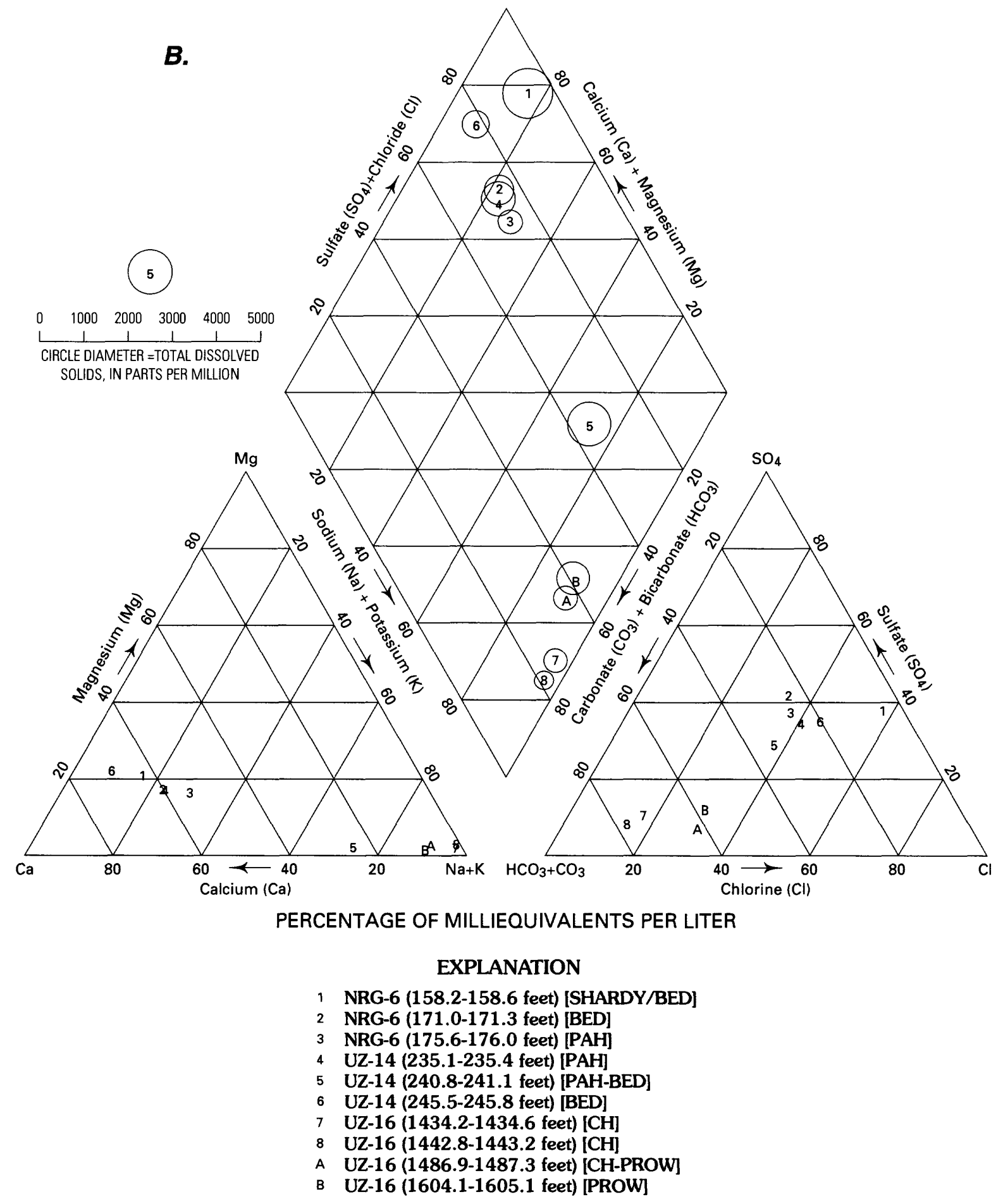

Figure 6. Piper diagram showing (A) USW NRG-6 and 7a pore-water composition, and (B) composition of lithologic contacts and adjacent beds from USW NRG-6, 7a, and unsaturated-zone boreholes-Continued. 
A.

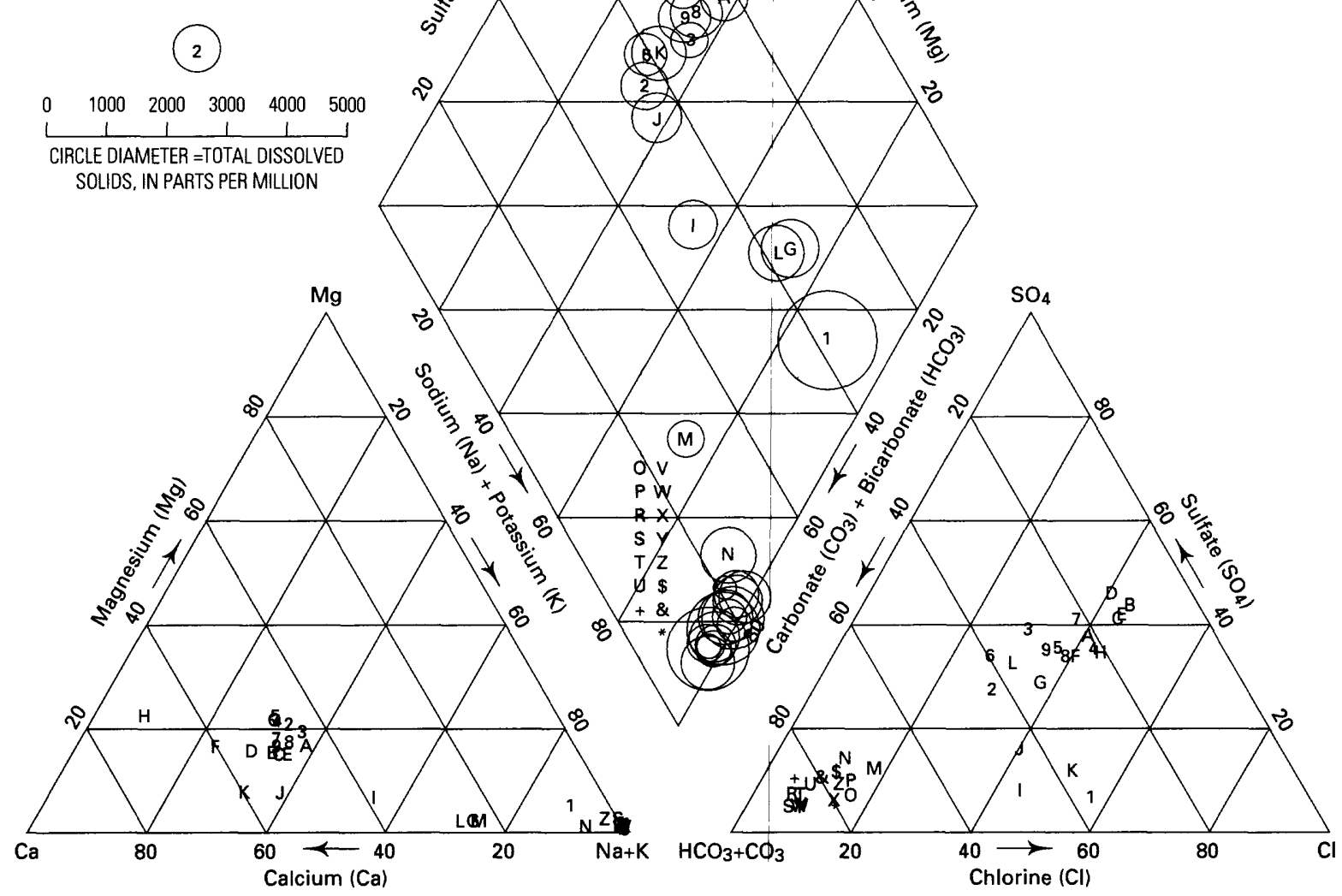

PERCENTAGE OF MILLIEQUIVALENTS PER LITER

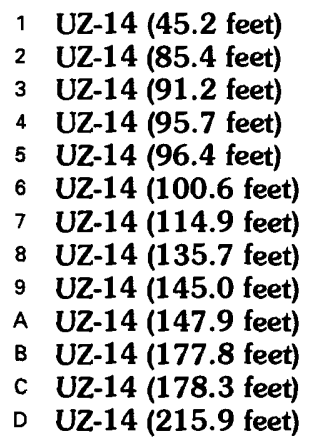

\section{EXPLANATION}

$\begin{array}{clcc}\text { E } & \text { UZ-14 (226.1 feet) } & \text { S } & \text { UZ-14 (1563.7 feet) } \\ \text { F } & \text { UZ-14 (235.3 feet) } & \text { T } & \text { UZ-14 (1564.7 feet) } \\ \text { G } & \text { UZ-14 (241.0 feet) } & \text { U } & \text { UZ-14 (1565.0 feet) } \\ \text { H } & \text { UZ-14 (245.7 feet) } & \text { V } & \text { UZ-14 (1585.1 feet) } \\ \text { I } & \text { UZ-14 (1258.7 feet) } & \text { W } & \text { UZ-14 (1585.5 feet) } \\ \text { J } & \text { UZ-14 (1277.6 feet) } & \text { X } & \text { UZ-14 (1606.0 feet) } \\ \text { K } & \text { UZ-14 (1277.9 feet) } & \text { Y } & \text { UZ-14 (1644.4 feet) } \\ \text { L } & \text { UZ-14 (1409.6 feet) } & \text { Z } & \text { UZ-14 (1675.0 feet) } \\ \text { M } & \text { UZ-14 (1419.7 feet) } & \$ & \text { UZ-14 (1695.5 feet) } \\ \text { N } & \text { UZ-14 (1462.0 feet) } & \& & \text { UZ-14 (1715.2 feet) } \\ \text { o } & \text { UZ-14 (1495.9 feet) } & * & \text { UZ-14 (1734.6 feet) } \\ \text { P } & \text { UZ-14 (1524.7 feet) } & + & \text { UZ-14 (2104.1 feet) } \\ \text { R } & \text { UZ-14 (1542.6 feet) } & & \end{array}$

Flgure 7. Piper diagram showing pore-water composition of (A) USW UZ-14 and (B) UE-25 UZ\#16. 


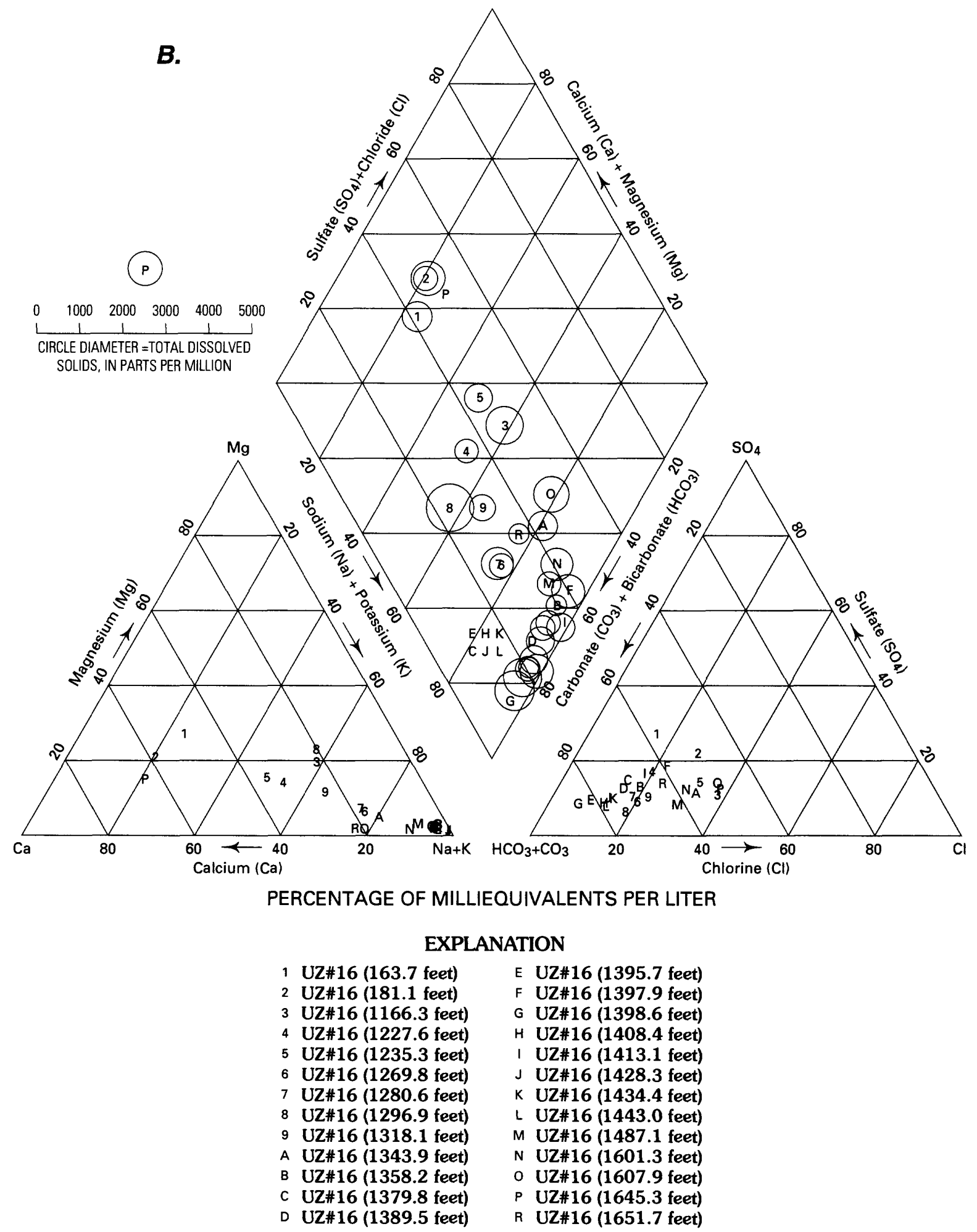

Flgure 7. Piper diagram showing pore-water composition of (A) USW UZ-14 and (B) UE-25 UZ\#16-Continued. 
Table 5. Comparison of pore-water composition in lithologic contacts and adjacent beds, Yucca Mountain, Nevada

[m, meters; $\mathrm{mg} / \mathrm{L}$, milligrams per liter]

\begin{tabular}{|c|c|c|c|c|c|c|c|}
\hline $\begin{array}{c}\text { Sample } \\
\text { identification }\end{array}$ & $\begin{array}{l}\text { Symbol } \\
\text { in Piper } \\
\text { diagram } \\
\text { (fig. 6B) }\end{array}$ & $\begin{array}{l}\text { Average } \\
\text { Depth } \\
\text { (m) }\end{array}$ & $\begin{array}{c}\text { Aluminum } \\
\text { Al* }^{*} \\
\text { (mg/L) }\end{array}$ & $\begin{array}{c}\text { Caicium } \\
\text { Ca } \\
\text { (mg/L) }\end{array}$ & $\begin{array}{c}\text { Magnesium } \\
\text { Mg } \\
(\mathbf{m g} / L)\end{array}$ & $\begin{array}{c}\text { Sodium } \\
\mathrm{Na} \\
\text { (mg/L) }\end{array}$ & $\begin{array}{c}\text { Bicarbonate } \\
\mathrm{HCO}_{3} \\
\text { (mg/L) }\end{array}$ \\
\hline NRG-6/158.2-158.6 (Shardy base/bedded) & 1 & 48.28 & 0 & 122 & 23.3 & 35.6 & 34 \\
\hline NRG-6/171.0-171.3 (Bedded) & 2 & 52.18 & 0 & 70.5 & 11.5 & 29.2 & 48 \\
\hline NRG-6/175.6-176.0 (Pah Canyon) & 3 & 53.58 & 0 & 49.2 & 8.6 & 29.4 & 60 \\
\hline UZ-14/235.1-235.4 (Pah Canyon) & 4 & 71.72 & 0.0 & 67 & 10.5 & 29 & 96 \\
\hline UZ-14/240.8-241.1 (Pah Canyon/Bedded) & 5 & 73.46 & 3 & 32 & 1 & 103 & 162 \\
\hline UZ-14/245.5-245.8 (Bedded) & 6 & 74.89 & $\mathbf{0}$ & 65 & 12 & 9 & 66 \\
\hline UZ-16/1434.2-1434.6 (Calico Hills) & 7 & 437.21 & 6.1 & 3.2 & 0.6 & 113 & 59 \\
\hline UZ-16/1442.8-1443.2 (Calico Hills) & 8 & 439.83 & 1.2 & 1.7 & 0.8 & 79.9 & 15 \\
\hline UZ-1 6/1486.9-1487.3 (Calico Hills/Prow Pass) & A & 453.27 & 26.2 & 6.3 & 0.8 & 79.5 & 137 \\
\hline UZ-16/1601.1-1601.5 (Prow Pass) & B & 488.08 & 0.7 & 10 & 0.3 & 100 & 181 \\
\hline $\begin{array}{c}\text { Sample } \\
\text { identification }\end{array}$ & \multicolumn{2}{|c|}{$\begin{array}{c}\text { Carbonate } \\
\mathrm{CO}_{3} \\
(\mathrm{mg} / \mathrm{L})\end{array}$} & $\begin{array}{c}\text { Chloride } \\
\text { Cl } \\
\text { (mg/L) }\end{array}$ & $\begin{array}{c}\text { Bromine } \\
\mathrm{Br} \\
(\mathrm{mg} / \mathrm{L})\end{array}$ & $\begin{array}{c}\text { Nitrate } \\
\mathrm{NO}_{3} \\
(\mathrm{mg} / \mathrm{L})\end{array}$ & $\begin{array}{c}\text { Sulfate } \\
\mathrm{SO}_{4} \\
(\mathbf{m g} / \mathrm{L})\end{array}$ & $\begin{array}{c}\text { Silica } \\
\mathrm{SiO}_{2} \\
(\mathrm{mg} / \mathrm{L})\end{array}$ \\
\hline NRG-6/158.2-158.6 (Shardy base/bedded) & \multirow{2}{*}{\multicolumn{2}{|c|}{$\begin{array}{r}0 \\
13\end{array}$}} & 185 & 1 & 32 & 159 & 97.4 \\
\hline NRG-6/171.0-171.3 (Bedded) & & & 58 & $\mathbf{0}$ & 43 & 94 & 79.4 \\
\hline NRG-6/175.6-176.0 (Pah Canyon) & \multicolumn{2}{|l|}{$\mathbf{0}$} & 47 & $\mathbf{0}$ & 42 & 64 & 78.1 \\
\hline UZ-14/235.1-235.4 (Pah Canyon) & \multicolumn{2}{|l|}{$\mathrm{N} / \mathrm{S}$} & 84 & 0 & 15 & 94 & 63 \\
\hline UZ-14/240.8-241.1 (Pah Canyon/Bedded) & \multicolumn{2}{|l|}{$\mathrm{N} / \mathrm{S}$} & 99 & $\mathbf{0}$ & 17 & 100 & 61 \\
\hline UZ-14/245.5-245.8 (Bedded) & $\mathrm{N} / \mathrm{S}$ & & 77 & $\mathbf{0}$ & 12 & 79 & 46 \\
\hline UZ-16/1434.2-1434.6 (Calico Hills) & 118 & & 23 & $\mathbf{0}$ & 16 & 19 & 109.1 \\
\hline UZ-16/1442.8-1443.2 (Calico Hills) & 146 & & 18.9 & $\mathbf{0}$ & 11.3 & 13.7 & 68.9 \\
\hline UZ-16/1486.9-1487.3 (Calico Hills/Prow Pass) & 0 & & 38 & 0 & 6 & 11 & 233.3 \\
\hline UZ-16/1601.1-1601.5 (Prow Pass) & 0 & & 53 & 0 & 13 & 27 & 36 \\
\hline
\end{tabular}

${ }^{*} 0.45-\mu \mathrm{m}$ filter paper was used, hence, particulate aluminum is likely included in these values.

For pore water extracted from lithologic contacts and adjacent beds, the pore-water compositions are shown in figure 6B. A shardy base/bedded tuff contact in the NRG-6 borehole is shown by symbol 1 and a Pah Canyon/bedded tuff contact in the USW UZ-14 borehole is shown by symbol 5 . Both of these pore waters have larger dissolved-solids values (about $1,200 \mathrm{mg} / \mathrm{L}$ ) than the adjacent bed pore waters represented by symbols 4 and 6 in figure $6 \mathrm{~B}$. This is likely due to the fact that more water is flowing through the adjacent beds than along contacts.

More water flow will cause pore water to be dilute. A water from a lithologic contact of the Calico Hills Formation/Prow Pass in the UE-25 UZ\#16 borehole is shown by $\mathrm{A}$ in figure $6 \mathrm{~B}$, which does not show a larger value of dissolved solids. However, this pore water is very high in aluminum $(\mathrm{Al}, 26.2 \mathrm{mg} / \mathrm{L})$ and silica $\left(\mathrm{SiO}_{2}, 233.3 \mathrm{mg} / \mathrm{L}\right.$ ) concentrations (table 5). In most pore waters from bedded tuff and the Calico Hills Formation, aluminum ( $\mathrm{Al}$ ) concentrations are from zero to $2 \mathrm{mg} / \mathrm{L}$, and silica $\left(\mathrm{SiO}_{2}\right)$ concentrations are from 50 to $100 \mathrm{mg} / \mathrm{L}$. These pore-water compositions and total dissolved solids in the lithologic contacts and adjacent beds are interesting observations. Although more data are needed to substantiate these observations, they may imply that percolating water is rerouted above the lithologic contacts and flows laterally through tilted porous tuffs (such as bedded tuff or Calico Hills Formation).

Finally, figures $7 \mathrm{~A}$ and $7 \mathrm{~B}$ present the compositions of pore water from USW UZ-14 and UE-25 UZ\#16 boreholes. In general, the trends are 
consistent in that ground waters are calcium bicarbonate, sulfate, or chloride type of shallow depths (top of diamond in the Piper diagram) and sodium bicarbonate or carbonate types (near the bottom of diamond) in the Calico Hills Formation. The composition of the porewater sample from $13.8 \mathrm{~m}(45.2 \mathrm{ft})$ in USW UZ-14 is an exception to this trend shown by point 1 in figure $7 \mathrm{~A}$. This core sample is in the Yucca Mountain Tuff, and the pore water has very high concentrations of dissolved solids. The chemical composition is not the calcium chloride or sulfate type typical of the shallow-depth pore water, but it is similar to the Topopah Spring Tuff pore water, which has an intermediate composition on the diagram (points $G$ and $L$ ). Repeated concentration of pore water by evaporation and/or extended water-rock interactions might result in the observed larger dissolvedsolids concentration.

Compositions of pore water from the upper Calico Hills Formation of UE-25 UZ\#16 are shown by symbols 4 and 5 in figure $7 \mathrm{~B}$. These waters have less water-rock interactions in the Calico Hills Formation and are similar to the water type of a Topopah Spring Tuff. Also, a core at $501.5 \mathrm{~m}(1,645 \mathrm{ft})$ deep in the Prow Pass Tuff of UZ\#16 is shown by symbol $P$ in figure 7B, which shows a chemical composition similar to symbol 1 at a shallow depth of only $49.8 \mathrm{~m}$ (164 ft) in the same borehole (fig. 7B). This suggests that young waters are rapidly transported through fractures with little waterrock interaction and are present in the upper Calico Hills Formation or Prow Pass Tuff of UE-25 UZ\#16. This is chemical evidence that preferential flow occurred around UE-25 UZ\#16. The faults and fault zones and Sundance fault near this borehole may contribute to fast-flow paths (Spengler and others, 1994).

\section{Tritium}

The tritium concentration in precipitation before the atmospheric nuclear tests (pre-1952) was about 10 TU (Davis and Bentley, 1982). However, between 1952 and 1963, the United States and the Union of Soviet Socialist Republics conducted a series of atmospheric nuclear tests in the northern hemisphere that produced significant amounts of tritium in the Earth's atmosphere. As a result, the tritium concentration in precipitation increased rapidly from 1952 and peaked in the early 1960's. Michael (1989) reported a yearly tritium-concentration average of 2,700 TU in precipitation collected in 1963 at a Salt Lake City, Utah, station. A nuclear-test ban in 1963 stopped further tests in the atmosphere, and the tritium concentration gradually decreased to the present level of about 10 to $40 \mathrm{TU}$ measured in precipitation at the Nevada Test Site (Milne and others, 1987).

Water content and tritium data for pore water extracted from cores from UE-25 UZ\#4 and UZ\#5 are shown in figures $8 \mathrm{~A}$ and $8 \mathrm{~B}$. The tritium concentrations range from zero to $45 \mathrm{TU}$ in UZ\#4, and the peak concentration is at about $46-49 \mathrm{~m}$ (fig. 8A). In UZ\#5, the peak concentration of $75 \mathrm{TU}$ is at about $32 \mathrm{~m}$ (fig. 8B). The larger tritium concentrations at these depths relative to the tritium concentrations of 30 to 40 TU in precipitation during the 1980's are likely the result of water infiltrated in the early 1960's. No tritium data were obtained from the surface to a depth of $25 \mathrm{~m}$ in borehole UZ\#5 because the cores were not available for pore-water extraction. Similarly, no tritium data are available between 50 and $95 \mathrm{~m}$ in UZ\#4 and between 47 and $67 \mathrm{~m}$ in UZ\#5. (Tritium data for UZ\#4 and UZ\#5 were collected prior to implementation of the approved U.S. Geological Survey Yucca Mountain Project quality-assurance program and, therefore, the data are not qualified.)

USW UZ-14 tritium-concentration profiles from pore waters are shown in figure 9 . They do not show any significantly large concentrations. However, there are several peaks at 18 to $30 \mathrm{TU}$ in the Pah Canyon Tuff that likely are from the postbomb era.

Only small intervals of the NRG -6 and NRG -7 a cores were analyzed for pore-water tritium and ${ }^{14} \mathrm{C}$. The data are shown in figures $10 \mathrm{~A}$ and $10 \mathrm{~B}$. High tritium concentrations of about 30 to $150 \mathrm{TU}$ in a broad peak are observed in NRG-6 boreholes (fig. 10A) from $53.3 \mathrm{~m}$ to $74.7 \mathrm{~m}$ in the Pah Canyon Tuff, and near the top of Topopah Spring Tuff.

Tritium concentrations from UE-25 UZ\#16 are plotted in figure 11. An extremely high concentration of about $150 \mathrm{TU}$ is observed at a depth of $48 \mathrm{~m}$ just above the bedded tuff unit, which is similar in location to the high tritium values in UZ\#4, UZ\#5, and NRG-6 near the bedded and Pah Canyon Tuffs. In addition, several postbomb peaks are observed in the Topopah Spring Tuff at depths of $80 \mathrm{~m}, 204 \mathrm{~m}$, and $317 \mathrm{~m}$ to $357 \mathrm{~m}$ in UE-25 UZ\#16. Other large peaks, in figure 12, are seen in the Calico Hills Formation at depths of $426 \mathrm{~m}$ (44 TU) and $437 \mathrm{~m}$ (103 TU). 
$\perp \exists \exists \exists \mathrm{NI}$ ' $H \perp d \exists O$

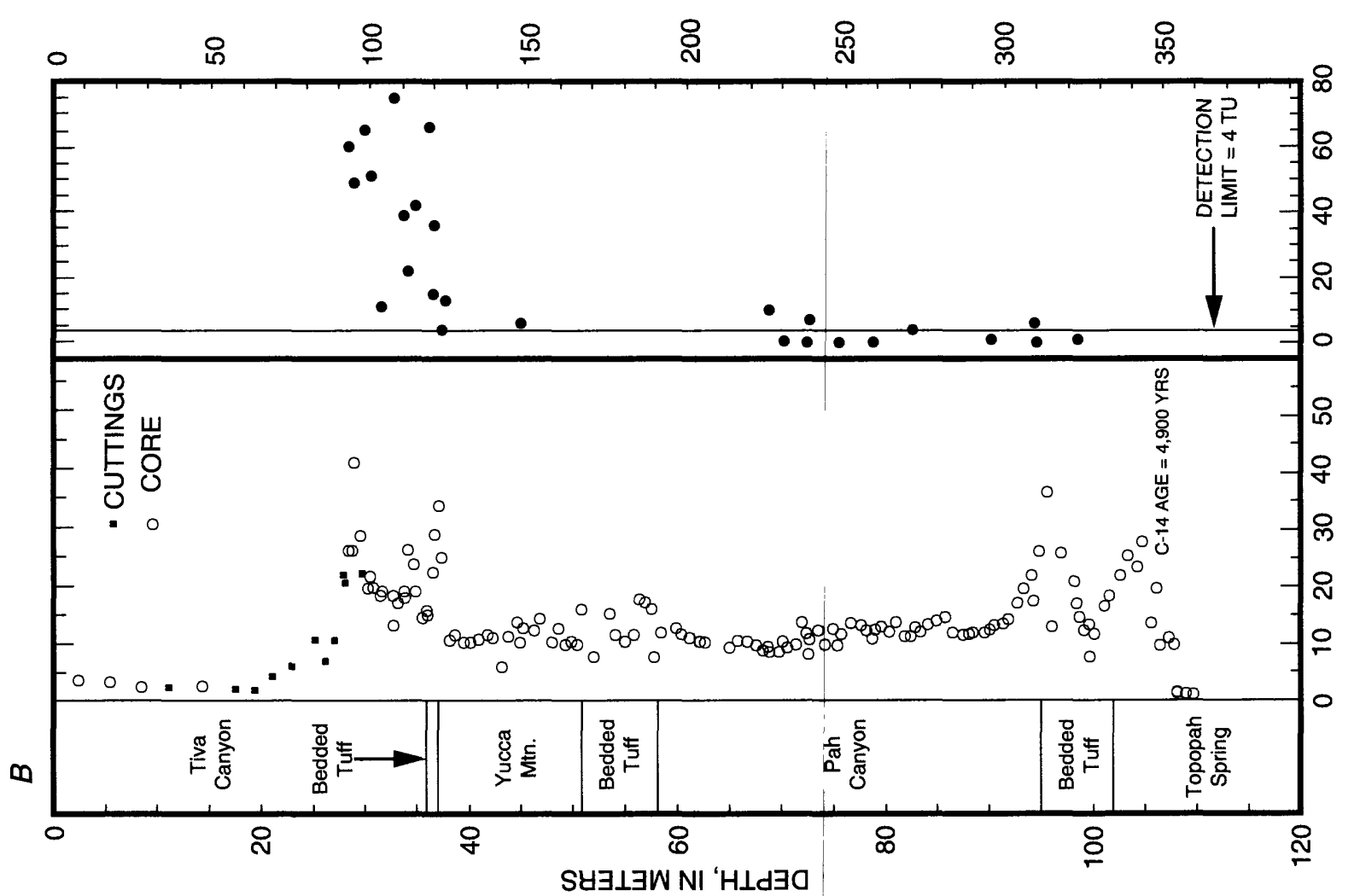

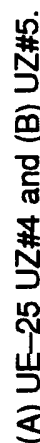

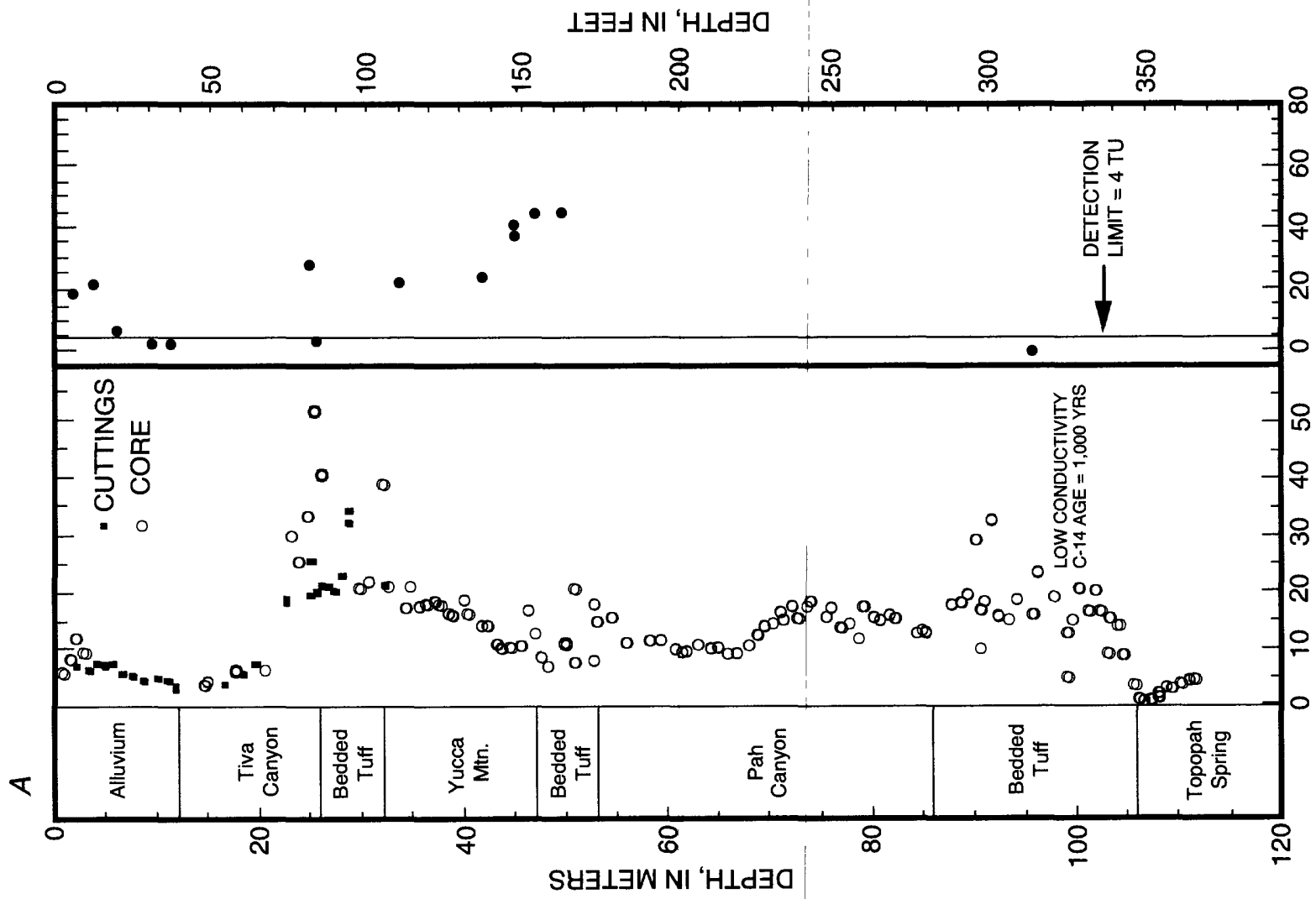

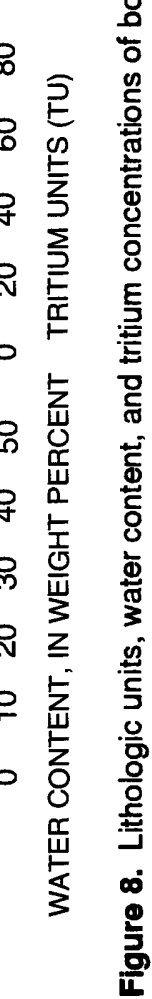




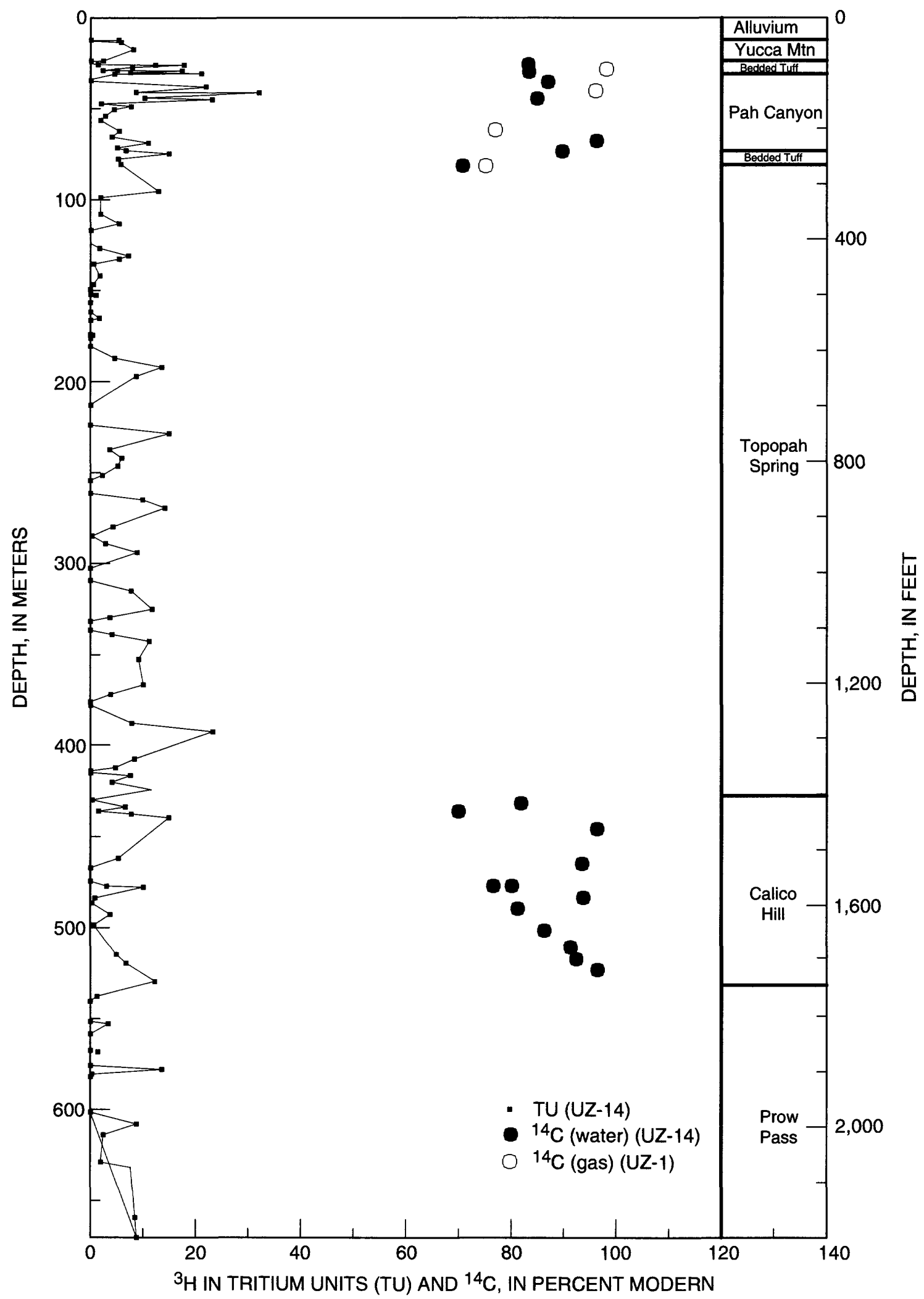

Figure 9. Tritium and carbon-14 data from USW UZ-14 pore water and rock-gas carbon-14 data from USW UZ-1. 

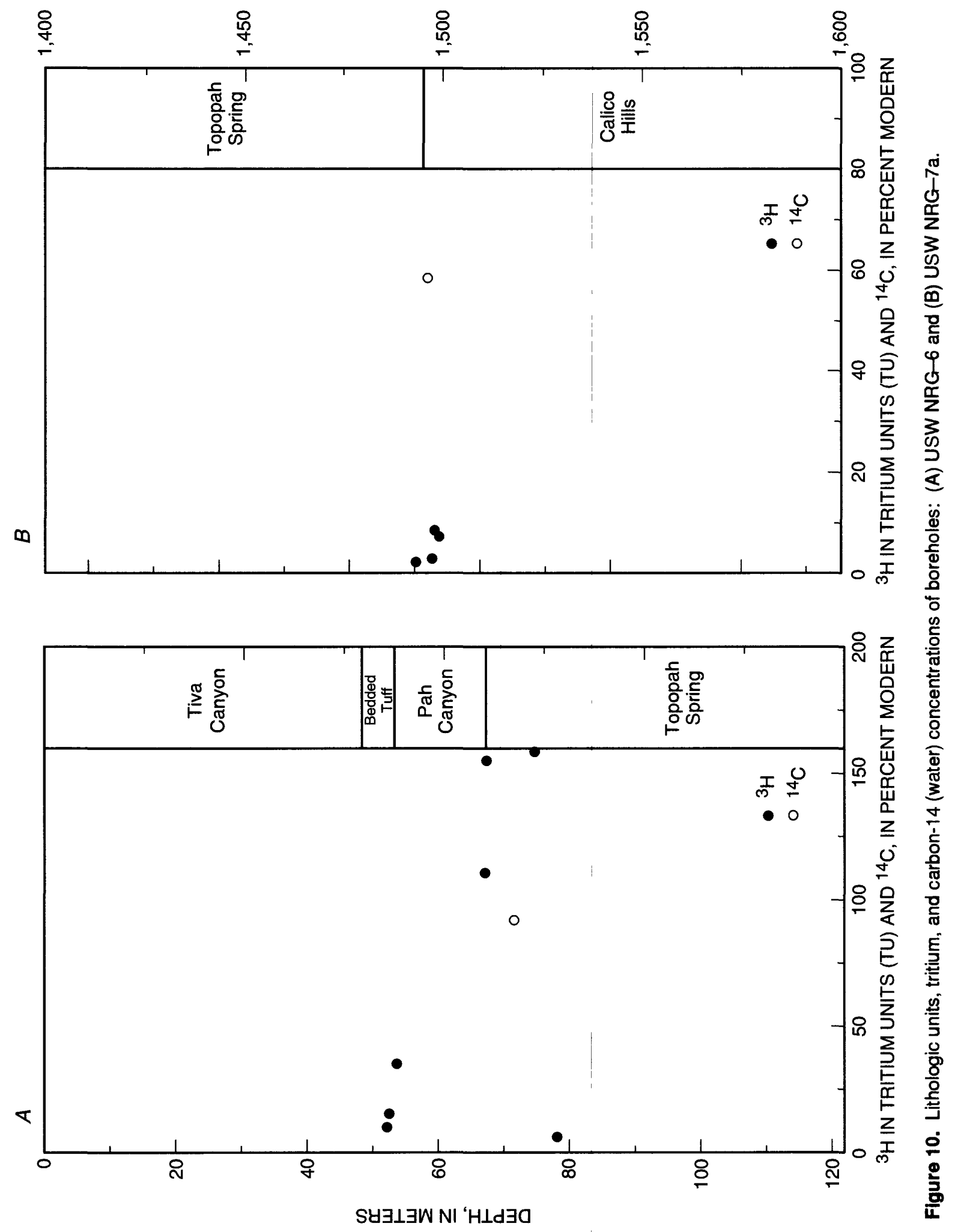


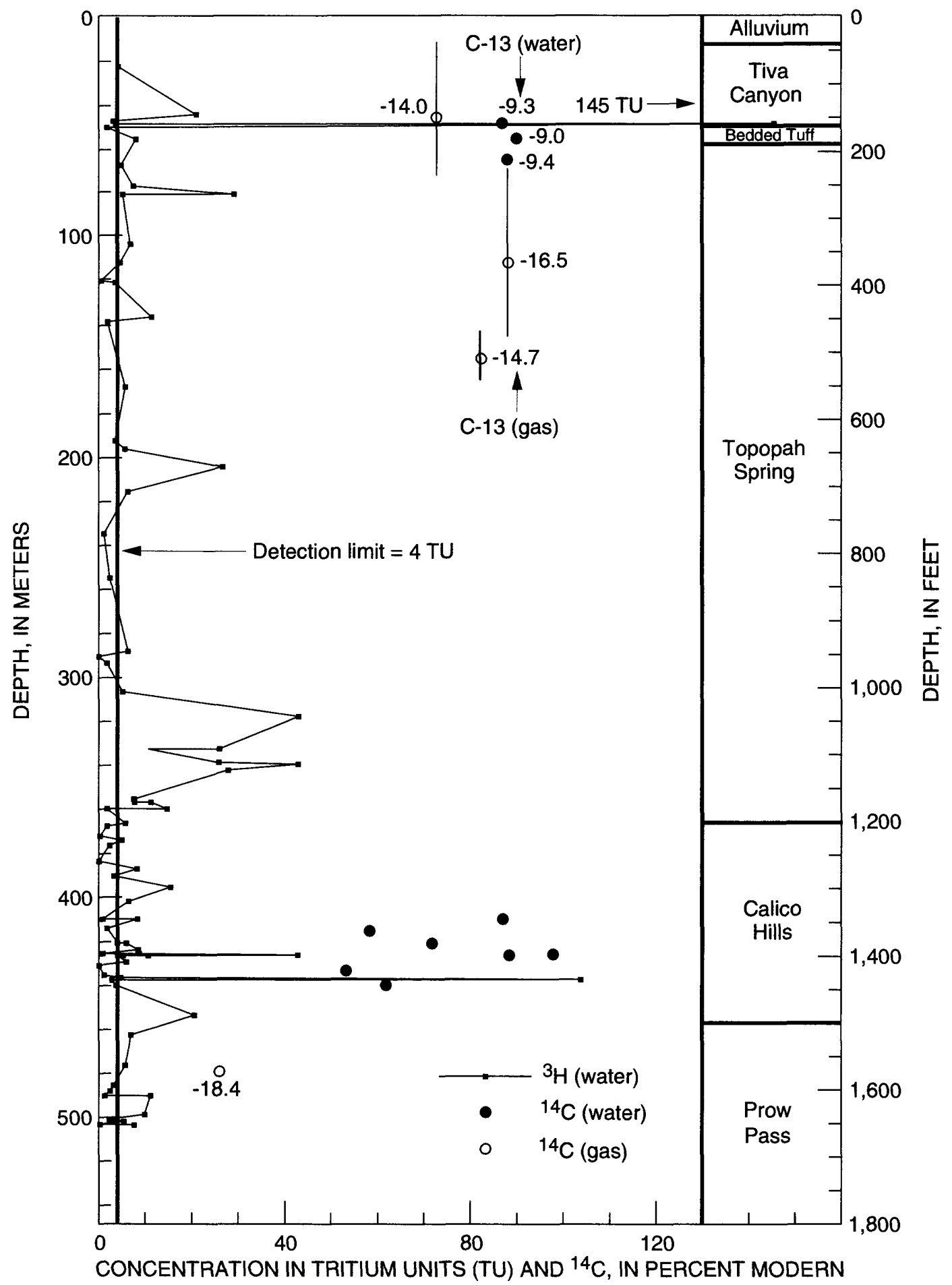

Figure 11. Lithologic units, tritium, and carbon-14 (gas and water) concentrations of borehole UE-25 UZ\#16. Lines through gas data indicate zone of sample collection. 


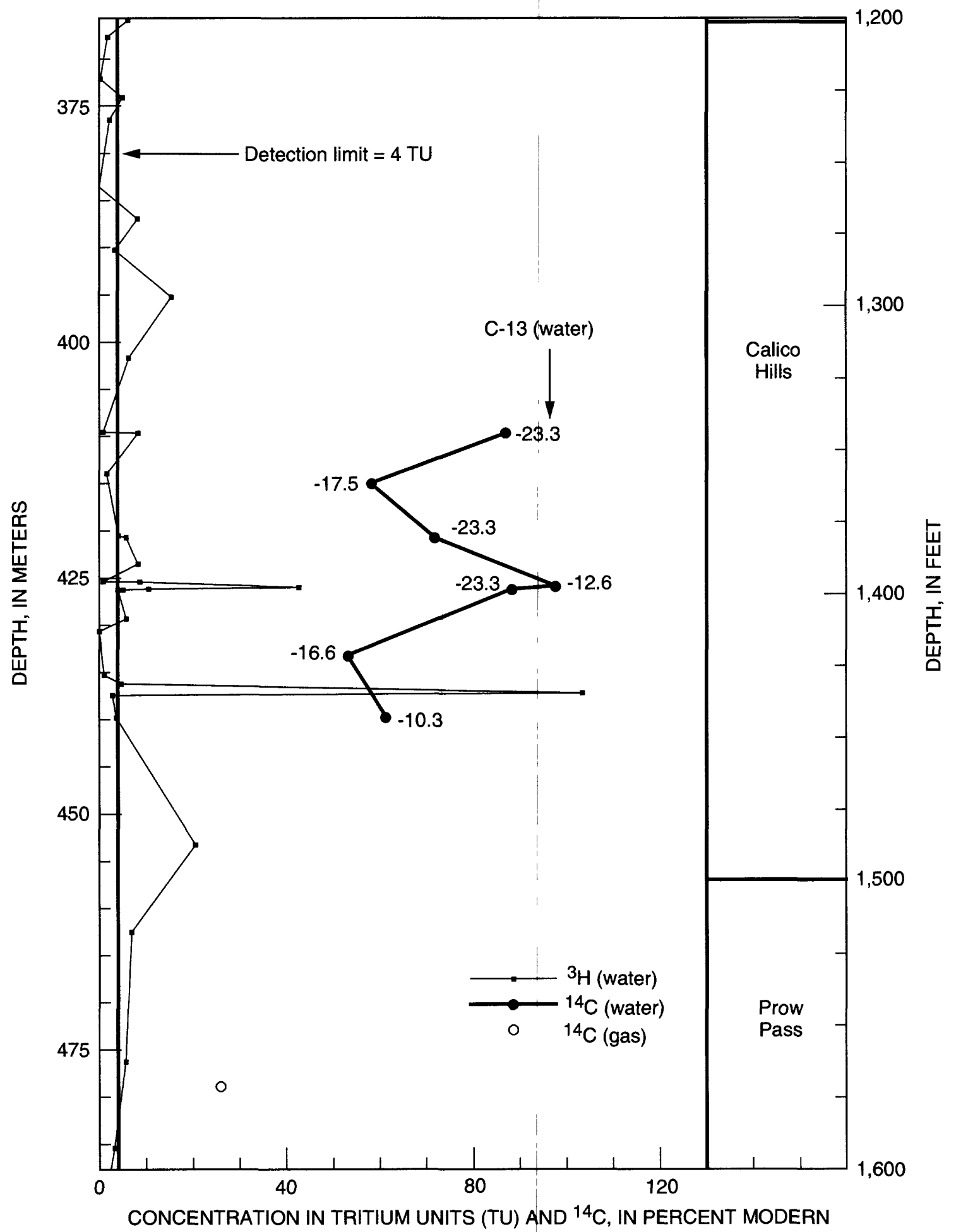

Figure 12. Expanded graph of tritium, carbon-14, and carbon-13 data from figure 11, UE-25 UZ\#16. 
Postbomb tritium concentrations down to the depth of $60 \mathrm{~m}$ were observed in the past (Yang, 1992). However, the large postbomb tritium concentrations found in the Calico Hills Formation of UZ\#16 were unexpected. Possible laboratory contaminations were initially suspected, and much effort was devoted to identifying possible sources of contamination. Measurements were made on the laboratory air and storage room (cold room) air in Denver for tritium concentrations, which were about 60 to $100 \mathrm{TU}$. If contamination occurred, it should affect all samples, not just a few. If radon contamination was present, then the high activity should disappear after a month due to a short half-life of radon gas (3.5 days). A recount of the same sample after a month still showed the high activity. Therefore, radon contamination was ruled out. Possible $\mathrm{Pb}-210$ contamination was considered but was unlikely because water samples for tritium measurements were distilled from cores. Inorganic lead $(\mathrm{Pb})$ compounds are nonvolatile at these temperatures.

From the tritium data observed in the boreholes mentioned above, tritium-concentration inversions (larger tritium concentrations located below the smaller tritium concentration in a vertical profile) occurred in many places. These inversions indicate that vertical water percolation through the matrix is not a normal flow mechanism at Yucca Mountain. Postbomb tritium concentrations were observed down to bedded tuff or Pah Canyon Tuff in many boreholes. The occurrence of postbomb tritium waters (recent water) below old water in a vertical profile is strong evidence of fracture flows occurring at Yucca Mountain. With regard to postbomb tritium concentrations observed at the Calico Hills Formation of UZ\#16, we believe these postbomb tritium peaks are real unless they can be proven otherwise. However, the flux is very small because the tritium-peak shape is so narrow. A large flux should result in a broader peak.

Supporting evidence of the above conclusions can be seen from the ${ }^{14} \mathrm{C}$ and ${ }^{36} \mathrm{Cl}$ data. Liu and others (1995) reported modern ${ }^{36} \mathrm{Cl}$ values in the Calico Hills Formation of UZ\#16. The ${ }^{14} \mathrm{C}$ values obtained from pore water of UZ\#16 in the Calico Hills Formation also showed young ages near the locations where the high tritium concentrations were found. It has been reported by Spengler and others (1994) that the Sundance fault, trending from northwest to southeast at Yucca Mountain, crosses near the UE-25 UZ\#16 borehole. Only fracture flow can explain the observed rapid percolation.

Field observations have shown that: (1) several neutron-access boreholes in washes accumulated 30 to $60 \mathrm{~cm}$ of water at the bottom of the boreholes after storms or periods of spring snowmelt and disappeared the next day (Alan Flint, U.S. Geological Survey, oral commun., 1993); and (2) in boreholes USW SD-9 and UE-25 UZ\#4, water was dripping down from a borehole wall near fractures (SD-9 and UZ\#4 from field $\log$ books). Also, many fractures (although not all) are coated with calcite minerals, as reported by Whelan and others $(1992,1994)$. These calcite deposits indicate that water has flowed through the fractures, depositing the minerals as they became saturated. These fractures are possible conduits for the rapid flow of young water to significant depths.

\section{Carbon Isotopes $\left(\delta^{13} \mathrm{C}\right.$ and $\left.{ }^{14} \mathrm{C}\right)$}

Only one carbon-isotope value was obtained for each borehole of UE-25 UZ\#4 and UZ\#5 because of the large amounts of time involved in compressing 50 to $90 \mathrm{~mL}$ of pore water from cores for each ${ }^{14} \mathrm{C}$ age determination. For other deeper boreholes, such as UE-25 UZ\#16 and USW UZ-14, core compression was conducted mostly on the high-moisture-content intervals (or units) (bedded tuff and Calico Hills Formation). Therefore, ${ }^{14} \mathrm{C}$ data from pore waters are mainly available from these intervals. The ${ }^{14} \mathrm{C}$ residence time of 1,000 years is indicated for water at a depth of 96.0 to $100.6 \mathrm{~m}$ (bedded unit above Topopah Spring Tuff) at UE-25 UZ\#4. The water ${ }^{14} \mathrm{C}$ residence time of 4,900 years at a depth of 103.5 to $105.2 \mathrm{~m}$ (in upper Topopah Spring Tuff) in borehole UE-25 UZ\#5 is older than water from the corresponding depth in UZ\#4 by nearly a factor of five (Yang, 1992). These abrupt changes in ${ }^{14} \mathrm{C}$ residence times support a rapid flow of younger water through fractures to the location where younger ${ }^{14} \mathrm{C}$ ages are observed (Yang, 1992).

For borehole USW UZ-1, there was no core recovered. Therefore, pore-water isotopic data are not available. However, because borehole USW UZ-14

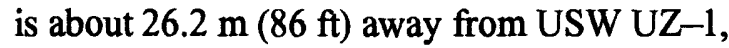
pore-water isotopic data from USW UZ-14 and 
UZ-1 should be representative of both boreholes. Carbon-14 data of pore water compressed from borehole USW UZ-14 cores are shown in figure 9 along with gaseous ${ }^{14} \mathrm{C}$ data from USW UZ-1. Water ${ }^{14} \mathrm{C}$ values (uncorrected) from the top $91 \mathrm{~m}(300 \mathrm{ft}$ ) ranging from 70 to $95 \mathrm{pmc}$ and are similar to values for the Calico Hills Formation pore-water ${ }^{14} \mathrm{C}$ values, which are between 70 and 96 pmc (uncorrected) between depths of 426.7 and $522.4 \mathrm{~m}$. It was unexpected to see ${ }^{14} \mathrm{C}$ values in the Calico Hills Formation of USW UZ-14 between 80 and 96 pmc even at a depth below $500 \mathrm{~m}$. This is quite different from borehole UE-25 UZ\#16 where seven ${ }^{14} \mathrm{C}$ values in the Calico Hills Formation of UE-25 UZ\#16 ranged from 53 to $98 \mathrm{pmc}$, with three of the values between 53 and $61 \mathrm{pmc}$ (see fig. 11 and discussion below). The apparent young ${ }^{14} \mathrm{C}$ or high ${ }^{14} \mathrm{C}$ pmc values could be related to: (1) young ${ }^{14} \mathrm{CO}_{2}$ in the gaseous phase possibly exchanging with the bicarbonate species in the pore water; and/or (2) the large amounts of cement used below a perched-water zone at $383.1 \mathrm{~m}$ $(1,257 \mathrm{ft})$ in order to seal off a borehole wall and prevent perched-water leakage (portland cement contains a small amount of $\mathrm{Ca}(\mathrm{OH})_{2}$, which will absorb atmospheric $\mathrm{CO}_{2}$ during mixing with water and release the $\mathrm{CO}_{2}$ during exothermic curation).

Figures 13A and 13B are expanded versions of the top $91 \mathrm{~m}^{14} \mathrm{C}$ data and the Calico Hills Formation ${ }^{14} \mathrm{C}$ data, respectively, for borehole UZ-14. From figure $13 \mathrm{~A}$, gas ${ }^{14} \mathrm{C}$ values are different from water ${ }^{14} \mathrm{C}$ values. This indicates that a nonequilibrium condition may exist between gaseous and aqueous phases. ${ }^{13} \mathrm{C}$ from gaseous and aqueous phases, and the $\mathrm{CO}_{2}$ (g) $-\mathrm{H}_{2} \mathrm{CO}_{3}$ (liq.)- $\mathrm{HCO}_{3}$ (liq.) system also shows a nonequilibrium condition (this will be explained in detail later in the section on $\delta^{13} \mathrm{C}$ Isotopic Ratio in Gaseous-Phase Chemistry of USW UZ-1). There are no gaseous-phase data in the Calico Hills Formation at present (1995). When borehole UZ-14 is instrumented, gaseousphase chemical and isotopic data will be collected and studied. If the gaseous-phase ${ }^{14} \mathrm{C}$ age from the Calico Hills Formation is significantly older than the aqueous-phase ${ }^{14} \mathrm{C}$ values, the apparent young ${ }^{14} \mathrm{C}$ ages in the aqueous phase will not be the result of gas $\mathrm{CO}_{2}$ and liquid bicarbonate exchange. The existence of cement in the borehole could release
$\mathrm{CO}_{2}$ gas during cement curation. If enough $\mathrm{CO}_{2}$ gas was reicased, potential contamination to pore water ${ }^{14} \mathrm{C}$ age could be significant.

Delta carbon- 13 values of pore water are shown in parenthesis in figures $13 \mathrm{~A}$ and $13 \mathrm{~B}$ near the respective ${ }^{14} \mathrm{C}$ data. It is unexpected to see $\delta^{13} \mathrm{C}$ data so widely spread $(-10.3$ to $-25 \%$ ) compared to perched water or saturated-zone waters. Soil $\mathrm{CO}_{2} \delta^{13} \mathrm{C}$ values have been measured at the Nevada Test Site in the last 3 years by E.A. McConnaughey (Science Applications International Corp., Denver, Colorado, written commun., 1995). Their measured $\delta^{13} \mathrm{C}$ values vary from year to year depending on the vegetation growth $(-10$ to $-25 \%)$, which in turn depends on the amount of precipitation. Therefore, ${ }^{14} \mathrm{C}$ ages of pore waters will be more variable if these changes exist. Furthermore, due to wide variations in ${ }^{14} \mathrm{C}$ ages of caliche that dissolved partially or totally into subsurface water, the uncertainty will be larger. It would be difficult to make a good age correction. However, a possible range of ages with some uncertainty can be assigned in the future when more data become available. At present, apparent ages will be used to make preliminary interpretations.

Carbon- 14 and $\delta^{13} \mathrm{C}$ data from UE-25 UZ\#16 are plotted in figures 11 and 12 . Pore-water ${ }^{14} \mathrm{C}$ data (uncorrected) from depths between 45.7 and $76.2 \mathrm{~m}$ $(150-250 \mathrm{ft})$ are all close to $88 \mathrm{pmc}$, and $\delta^{13} \mathrm{C}$ values range from -9.0 to $-9.4 \%$, indicating dissolution of caliche. The deeper ${ }^{14} \mathrm{C}$ data (uncorrected) in the Calico Hills Formation have a wider range of ${ }^{14} \mathrm{C}$ values ( 53 to $97 \mathrm{pmc}$ ): three in the range of 53 to $61 \mathrm{pmc}$, three in the range of 72 to $87 \mathrm{pmc}$, and one at $97 \mathrm{pmc}$. This wide scatter of ${ }^{14} \mathrm{C}$ values indicates preferential flow rather than a well-mixed unsaturatedzone water. The flux of the fast-flowing water is small judging from the narrow shape of the tritium peaks. One important consideration is the mixing of young ${ }^{14} \mathrm{C}$ age water with the old ${ }^{14} \mathrm{C}$ age water. As calculated by Liu and others (1995), for $99 \%$ volume of pore water (matrix water) having an age of 5,000 years mixed with a $1 \%$ volume of bomb-pulse component from the fracture fluid, the effect to the matrix ${ }^{14} \mathrm{C}$ age would be negligible. This mixing effect would not be significant until matrix water ages are more than 35,000 years. 


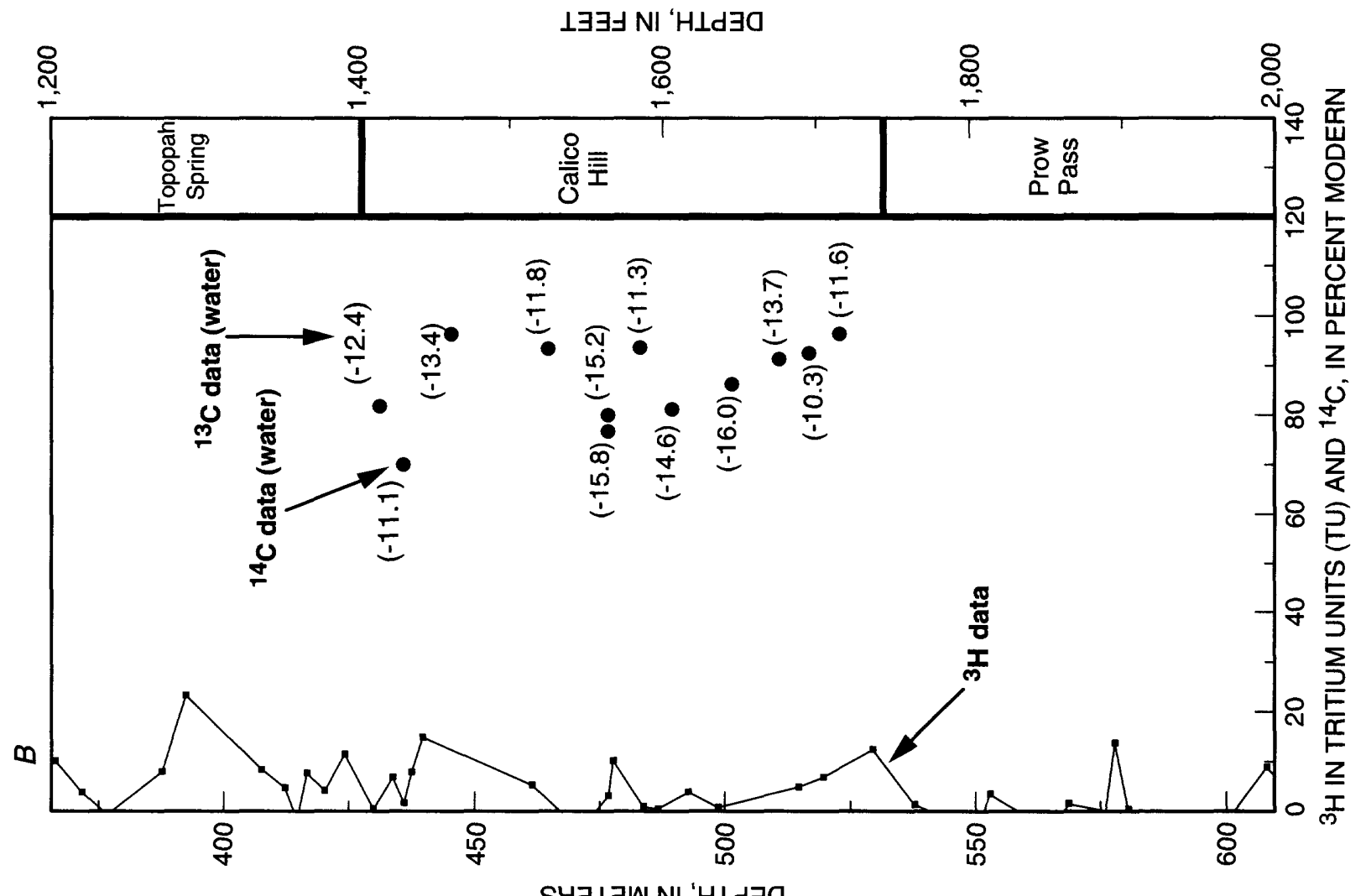

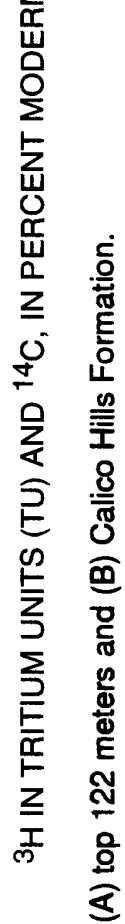

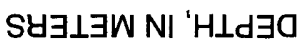

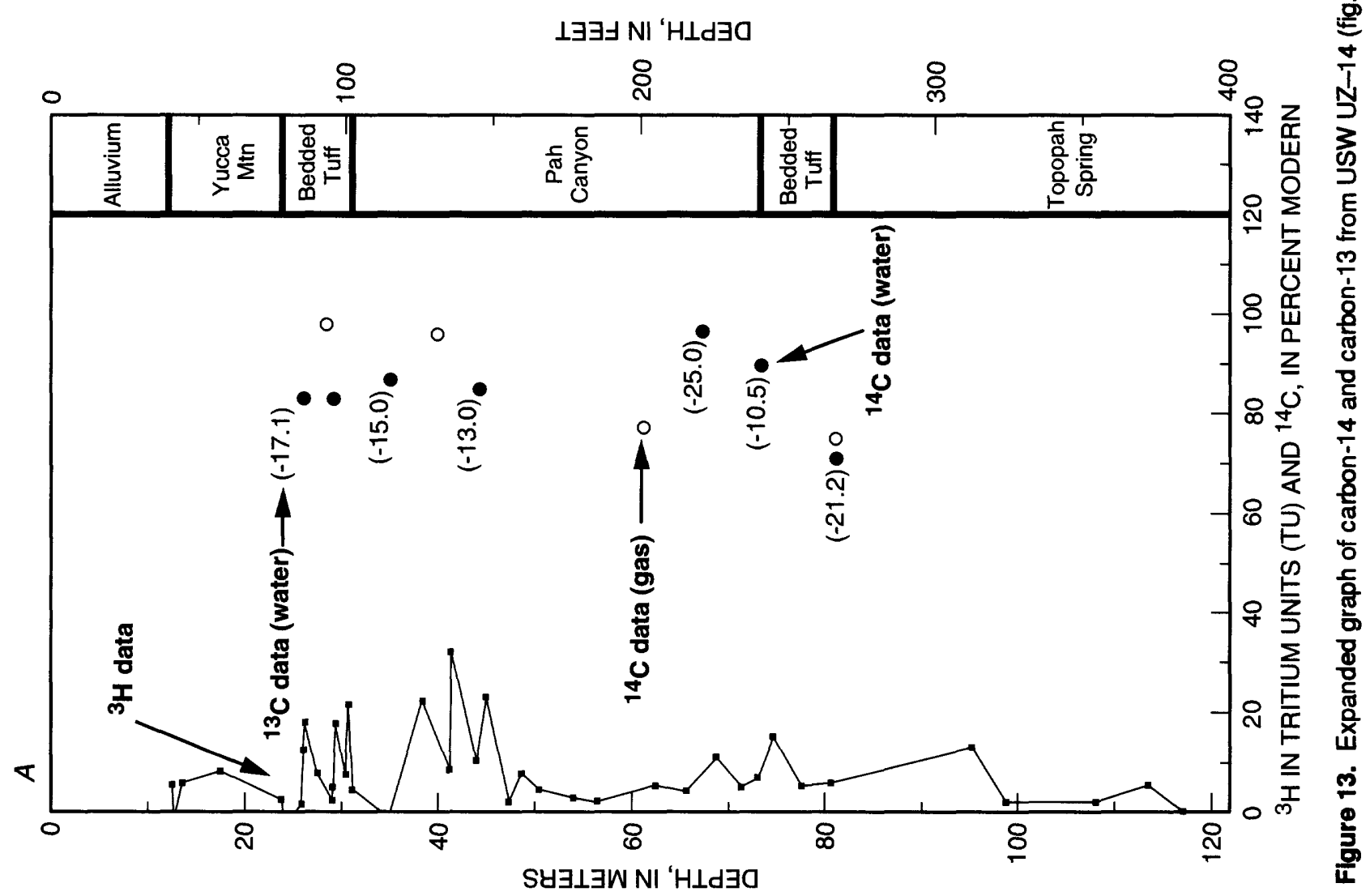


The other consideration is the exchange of younger ${ }^{14} \mathrm{CO}_{2}$ gas with the pore-water bicarbonate, resulting in younger pore water. Due to limited data at present, further confirmation from other boreholes is needed. The gaseous-phase ${ }^{14} \mathrm{C}$ data shown in figure 11 are not conclusive because the measured $\delta^{13} \mathrm{C}$ data are between $-14 \%$ and $-16.5 \%$, whereas the USW UZ-1 stemmed-borehole gas data are -18 to $-20 \%$. A possible air leak in the inflated packer system and the borehole wall or incomplete removal of air-contaminated rock gas can cause the shift in $\delta^{13} \mathrm{C}$ to the measured heavier values. However, one value in the Prow Pass from a depth of $477-481 \mathrm{~m}$ (1,565-1,578 ft) using a commercially constructed packer system has a ${ }^{14} \mathrm{CO}_{2}$ gas value of $25.8 \mathrm{pmc}$ and $\delta^{13} \mathrm{C}$ of $-18.4 \%$, similar to the USW UZ-1 value at depth.

\section{Perched Water}

Perched-water compositions from boreholes USW UZ-14, USW NRG-7a, USW SD-9, and SD-7 are presented in table 6 . The data are plotted in a Piper diagram in figure 14 along with ONC\#1 and USW G-2 samples collected from the saturated zone. Most of these perched-water zones were in the upper Calico Hills Formation, with the exception of UZ-14, which is in the Topopah Spring Tuff. As can be seen from table 6, major cation and anion concentrations were fairly constant throughout the pumping tests for USW UZ-14 and USW SD-7. Chloride concentration, which is hydrologically conservative, is fairly small ranging from about 4 to $8 \mathrm{mg} / \mathrm{L}$ except one at $15 \mathrm{mg} / \mathrm{L}$.

The composition of perched water located near or in the upper part of the Calico Hills Formation is, in general, closer to the pore-water composition of the Calico Hills Formation from UE-25 UZ\#16 and USW UZ-14 and also similar to saturated-zone water. But the chloride concentrations in all pore water are significantly larger than in the perched water. For example, perched waters collected from USW UZ-14 all have chloride concentration between 6 and $15 \mathrm{mg} / \mathrm{L}$ (represented by symbols $\mathrm{C}$ through $\mathrm{J}$ in fig. 14). In contrast, the chloride concentration of pore water compressed from USW UZ-14 cores obtained from perched-water zone (represented by symbols I and $\mathrm{J}$ in fig. $7 \mathrm{~A}$ ) are about $87.5 \mathrm{mg} / \mathrm{L}$. If matrix pore water contributes significantly to the perched-water body, then the chloride concentration of perched water should be similar to that of the pore water. This was not observed. The smaller concentration of chloride in perched water means that there is less interaction of fluid with rock, and that the source of the perched water flows through fractures. This is another point of evidence that fracture flows are the principal source of perched-water bodies at Yucca Mountain. In addition, the large chloride difference also indicates nonequilibrium conditions between the perched water and pore water. Furthermore, the compositions of the perched water are also different from pore water. Analyses of a USW UZ-14 perched-water sample collected before the pumping test (sample UZ-14C) indicated that the perched water contained a polymer that was used in the drilling of USW G-1 (Whitfield and others, 1990). If the polymer-contaminated perched water had a different chemical composition than the noncontaminated pore water, the chemical compositions between the two phases should be equilibrated after 10 years (USW UZ-1, which is only $26.2 \mathrm{~m}$ away from USW UZ-14, was drilled in 1985). It could be that trapped air in the porous medium prevents perched water from equilibrating with the pore water.

Perched-water isotopic-composition data are given in table 7. All perched waters contain background tritium concentration. If postbomb fracture waters are mixed in these perched waters, they are small in volume and subsequently are diluted by the large quantity of perched water, resulting in an undetectable tritium concentration.

Carbon- 14 and $\delta^{13} \mathrm{C}$ values are plotted in figures $15 \mathrm{~A}$ and $15 \mathrm{~B}$. As can be seen from the figures, the ${ }^{14} \mathrm{C}$ values range from 66.9 to $27.2 \mathrm{pmc}$, corresponding to apparent ${ }^{14} \mathrm{C}$ residence times of about 3,500 years to 11,000 years. Water ${ }^{14} \mathrm{C}$ ages are affected by the dissolution of older caliche by the infiltrating water. This dissolution can be identified by the $\delta^{13} \mathrm{C}$ isotopic values since caliche has $\delta^{13} \mathrm{C}$ values in the range of -3 to $-9 \%$ (Szabo and Kyser, 1985; Whelan and Stuckless, 1992), while biogenic $\mathrm{CO}_{2}$ has $\delta^{13} \mathrm{C}$ values of -18 to $-23 \%$ (UZ-1 data in this report). The heavier $\delta^{13} \mathrm{C}$ values in the water will indicate the dissolution of caliche in the ground water. Carbon-14 ages of caliche at Yucca Mountain have been dated and range from 20,000 to several hundred thousands of years (Whelan and others, 1994; Szabo and Kyser, 1985). 
Table 6. Chemical composition of perched water at Yucca Mountain, Nevada

$[\mu \mathrm{S} / \mathrm{cm}$, microsiemens per centimeter at 25 degrees Celsius; $\mathrm{mg} / \mathrm{L}$, milligrams per liter; - - -, data not available; 0 , values below detection limit; charge balance, (milliequivalent cation - milliequivalent anion)/(milliequivalent cation + milliequivalent anion) times 100]

\begin{tabular}{|c|c|c|c|c|c|c|c|c|c|c|}
\hline $\begin{array}{c}\text { Sample } \\
\text { identification }\end{array}$ & $\begin{array}{l}\text { Symbol } \\
\text { In Piper } \\
\text { diagram } \\
\text { (fig. 14) }\end{array}$ & $\begin{array}{c}\text { Average } \\
\text { depth } \\
\text { (meters) }\end{array}$ & Date & $\begin{array}{l}\text { Temperature } \\
\text { (degree } \\
\text { Celslus) }\end{array}$ & pH c & $\begin{array}{c}\text { Specific } \\
\text { conductance } \\
(\mu \mathrm{S} / \mathrm{cm})\end{array}$ & $\begin{array}{c}\text { Aluminum } \\
\text { Al } \\
\text { (mg/L) }\end{array}$ & $\begin{array}{c}\text { Calclum } \\
\text { Ca } \\
(\mathbf{m g} / \mathrm{L})\end{array}$ & $\begin{array}{c}\text { Magnesium } \\
\text { Mg } \\
(\mathbf{m g} / \mathrm{L})\end{array}$ & $\begin{array}{c}\text { Potasslum } \\
\text { K } \\
\text { (mg/L) }\end{array}$ \\
\hline$\overline{\text { NRG-7a }}$ & $\overline{\mathrm{A}}$ & 460.25 & $03-07-94$ & $\cdots$ & 8.7 & 224 & 0.0 & 3 & 0 & 6.8 \\
\hline SD_-9/TS & B & 453.85 & $07-17-94$ & 27.0 & 8.6 & 445 & 2.1 & 2.9 & 0.2 & 9.8 \\
\hline $\mathrm{UZ}-14 \mathrm{~A}$ & $\mathrm{C}$ & 384.60 & $08-02-93$ & 27.1 & 7.6 & 312 & 0.7 & 23 & 1.8 & 5.6 \\
\hline $\mathrm{UZ}-14$ A2 & D & 384.60 & $08-02-93$ & 27.1 & 7.8 & 308 & 1.0 & 24 & 1.8 & 3.9 \\
\hline UZ-14 B & E & 387.68 & $\begin{array}{cc}0 & -03-93\end{array}$ & 23.8 & 8.1 & 335 & 6.1 & 31 & 2.7 & 4.4 \\
\hline UZ-14 C & $\mathbf{F}$ & 390.75 & $08-05-93$ & 24.2 & 8.3 & 518 & 0.0 & 45 & 4.1 & 5.8 \\
\hline UZ-14 PT-1 & G & 390.75 & $08-17-93$ & .. & $\ldots$ & $\ldots$ & 0.0 & 37 & 3.1 & 6.3 \\
\hline $\mathrm{UZ}-14 \mathrm{PT}-2$ & $\mathbf{H}$ & 390.75 & $08-19-93$ & $\ldots$ & $\ldots$ & ... & 0.0 & 30 & 2.4 & 3.3 \\
\hline $\mathrm{UZ}-14 \mathrm{PT}-4$ & I & 390.75 & $08-27-93$ & $\ldots$ & $\cdots$ & $\ldots$ & 0.0 & 27 & 2.1 & 1.8 \\
\hline UZ-14 D & $\mathbf{J}$ & 390.75 & $08-31-93$ & $\ldots$ & 7.8 & $\cdots$ & 0.0 & 31 & 2.5 & 4.1 \\
\hline ONC\#1 & L & 432.97 & $12-15-94$ & $\ldots$ & 8.7 & 302 & 11 & 13.3 & 1.1 & 3.6 \\
\hline USW G-2 & $\mathbf{M}$ & 649.22 & $02-08-95$ & $\ldots$ & 7.7 & 259 & $\ldots$ & 7.9 & 0.5 & 5.2 \\
\hline $\mathrm{SD}-7(3 / 8)$ & $\mathrm{x}$ & 479.76 & $03-08-95$ & $\ldots$ & $\ldots$ & $\ldots$ & 0.28 & 14.2 & 0.13 & 5.3 \\
\hline $\mathrm{SD}-7(3 / 16)$ & $\mathrm{x}$ & 488.29 & $03-16-95$ & 21.8 & 8.1 & 239 & 0.44 & 13.3 & 0.13 & 5.3 \\
\hline SD-7(3/17) & $\mathrm{x}$ & 488.29 & 03-17-95 & 22.6 & 8.2 & 285 & 0 & 12.8 & 0.08 & 5.5 \\
\hline $\mathrm{SD}-7(3 / 20)$ & $\mathrm{x}$ & 488.29 & $03-20-95$ & 23.3 & 8.0 & 265 & 0 & 12.9 & 0.07 & 5.4 \\
\hline $\mathrm{SD}-7(3 / 21)$ & $\mathrm{x}$ & 488.29 & $03-21-95$ & 23.2 & 8.2 & 259 & 0 & 13.5 & 0.08 & 5.5 \\
\hline $\begin{array}{c}\text { Sample } \\
\text { identffication }\end{array}$ & \multicolumn{2}{|c|}{$\begin{array}{c}\text { Sodium } \\
\mathrm{Na} \\
(\mathbf{m g} / \mathrm{L})\end{array}$} & $\begin{array}{l}\text { Silica } \\
\text { sio } \\
\text { (mg/L) }\end{array}$ & $\begin{array}{l}\text { Icarbonate } \\
\mathrm{HCO}_{3}\end{array}$ & $\begin{array}{l}\text { arbonate } \\
\mathrm{CO}_{3} \\
\text { (mg/L) }\end{array}$ & $\begin{array}{c}\text { Chlorine } \\
\text { CL } \\
(\mathbf{m g} / L)\end{array}$ & $\begin{array}{c}\text { Bromine } \\
\text { Br } \\
(\mathbf{m g} / L)\end{array}$ & $\begin{array}{c}\text { Nitrate } \\
\mathrm{NO}_{3} \\
(\mathrm{mg} / \mathrm{L})\end{array}$ & $\begin{array}{l}\text { Sulfate } \\
\text { SO }_{4} \\
(\mathrm{mg} / \mathrm{L})\end{array}$ & $\begin{array}{l}\text { Charge } \\
\text { balance }\end{array}$ \\
\hline$\overline{N R G-7 a}$ & \multicolumn{2}{|c|}{42} & 9 & 114 & $\cdots$ & 7 & 0 & 1 & 4 & -1.9 \\
\hline SD—9/TS & \multicolumn{2}{|c|}{98} & 64.2 & 197 & 10 & 5.6 & 0 & 3.3 & 27.6 & -6.6 \\
\hline $\mathrm{UZ}-14 \mathrm{~A}$ & \multicolumn{2}{|c|}{39} & 34.2 & 150 & 0 & 7.9 & 0.2 & 8.6 & 14.3 & -0.1 \\
\hline $\mathrm{UZ}-14$ A2 & \multicolumn{2}{|c|}{38} & 36.4 & 148.8 & 0 & 9.1 & 0.1 & 12.5 & 13.8 & -0.2 \\
\hline UZ-14 B & \multicolumn{2}{|c|}{40} & 51.4 & 147.6 & 0 & 8.3 & 0.4 & 16.9 & 16.3 & 0.2 \\
\hline$U Z-14 \mathrm{C}$ & \multicolumn{2}{|c|}{88} & 7.7 & 106.1 & 0 & 15.5 & 0.4 & 0 & 223 & -0.4 \\
\hline UZ-14 PT-1 & \multicolumn{2}{|c|}{40} & 21.4 & 144.0 & 0 & 7.2 & 0.1 & 12.7 & 57.3 & -0.1 \\
\hline UZ-14 PT-2 & \multicolumn{2}{|c|}{35} & 25.7 & 144.0 & $\mathbf{0}$ & 7.0 & 0.1 & 15.4 & 22.9 & -0.1 \\
\hline $\mathrm{UZ}-14 \mathrm{PT}-4$ & 34 & & 32.1 & 141.5 & 0 & 6.7 & 0.1 & 14.5 & 14.1 & 0.1 \\
\hline UZ-14 D & 35 & & 40.7 & 146.4 & 0. & 7.0 & 0.1 & 17.1 & 24.2 & -0.3 \\
\hline ONC\#1 & 50 & 3.6 & 26.5 & 115 & 8.8 & 7.1 & 0 & 5.2 & 23.6 & 8.4 \\
\hline USW G-2 & 46 & & 51 & 116 & $\ldots$ & 6.5 & 0.1 & $\ldots$ & 13 & 6.9 \\
\hline SD-7(3/8) & 45 & 5.5 & 62.3 & 112 & 0 & 4.4 & 0 & 33.8 & 9.1 & -6.1 \\
\hline $\mathrm{SD}-7(3 / 16)$ & 45 & 5.3 & 57.4 & 128 & $\mathbf{0}$ & 4.1 & 0 & 33.8 & 9.1 & -4.6 \\
\hline $\mathrm{SD}-7(3 / 17)$ & 45 & 5.8 & 50.9 & 130 & 0 & 4.1 & 0 & 22.8 & 8.6 & -2.4 \\
\hline SD $-7(3 / 20)$ & 45 & 5.5 & 55 & 127 & 0 & 4.1 & 0 & 13.4 & 8.5 & 0.6 \\
\hline $\mathrm{SD}-7(3 / 21)$ & 44 & 4.6 & 55.9 & 128 & 0 & 4.1 & 0 & 13.2 & 10.3 & -1.0 \\
\hline
\end{tabular}



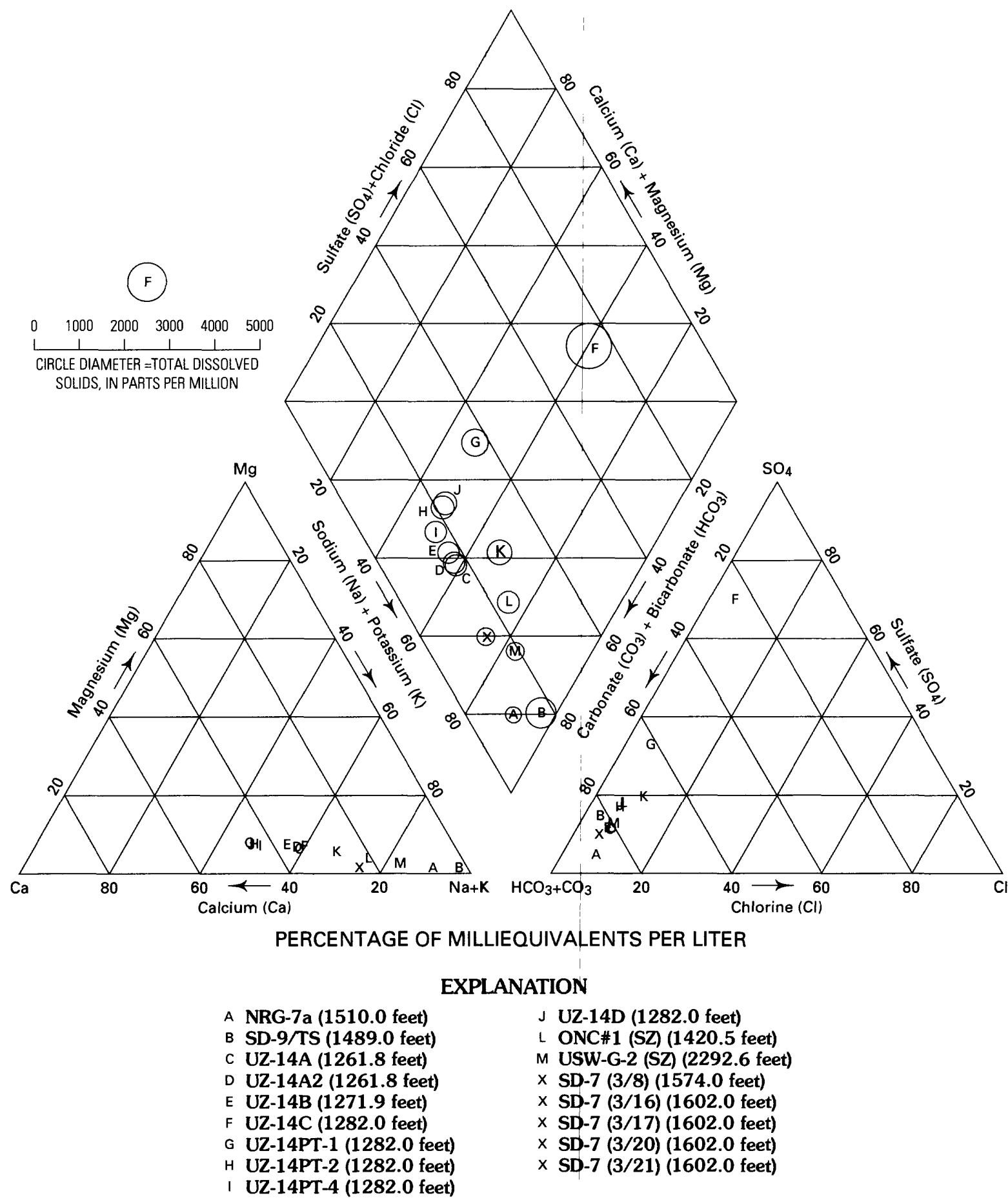

PERCENTAGE OF MILLIEQUIVALENTS PER LITER

\section{EXPLANATION}

J UZ-14D (1282.0 feet)

L ONC\#1 (SZ) (1420.5 feet)

M USW-G-2 (SZ) (2292.6 feet)

$x$ SD-7 (3/8) (1574.0 feet)

$x$ SD-7 (3/16) (1602.0 feet)

$x$ SD-7 (3/17) (1602.0 feet)

$x$ SD-7 (3/20) $(1602.0$ feet $)$

$x$ SD-7 (3/21) (1602.0 feet)

Figure 14. Piper diagram showing perched-water composition, along with saturated-zone water compositions (ONC\#1, L, and USW G-2, M). 
Table 7. Isotopic composition of perched water

[m, meter; \%o, parts per thousand; pmc, percent modern carbon; - - -, data not available; PDB, Pee Dee Belemnite standard; SMOW, Standard Mean Ocean Water]

\begin{tabular}{|c|c|c|c|c|c|c|c|}
\hline $\begin{array}{c}\text { Sample } \\
\text { identification }\end{array}$ & $\begin{array}{c}\text { Dopth } \\
\text { (m) }\end{array}$ & Date & $\begin{array}{l}\text { Carbon-13 } \\
{ }^{13} \mathrm{C} \\
\text { (\%, PDB) }\end{array}$ & $\begin{array}{c}\text { Carbon-14 } \\
{ }^{14} \mathrm{C} \\
\text { (pmc) }\end{array}$ & $\begin{array}{c}\text { Tritium } \\
\text { (trH } \\
\text { (tritum units) }\end{array}$ & $\begin{array}{c}\text { Deuterium } \\
\text { D } \\
(\%, \text { SMow) }\end{array}$ & $\begin{array}{c}\text { Oxygen-18 } \\
{ }_{18} 0 \\
\text { (\%., smow) }\end{array}$ \\
\hline $\mathrm{SD}-7(3 / 8)$ & 479.76 & $03-08-95$ & -10.4 & 34.4 & 6.2 & -99.8 & -13.4 \\
\hline SD-7(3/16) & 488.29 & $03-16-95$ & -9.4 & 28.6 & $\cdots$ & -99.7 & -13.3 \\
\hline SD-7(3/17) & 488.29 & $03-17-95$ & -9.5 & 28.4 & --- & -99.6 & -13.4 \\
\hline $\mathrm{SD}-7(3 / 20)$ & 488.29 & $03-20-95$ & -9.5 & 27.9 & -- & -99.6 & -13.4 \\
\hline $\mathrm{SD}-7(3 / 21)$ & 488.29 & $03-21-95$ & -9.5 & 28.4 & -- & -99.6 & -13.3 \\
\hline SD-9/TS & 453.85 & $07-17-94$ & -14.4 & 41.8 & 0.0 & -97.8 & -13.3 \\
\hline UZ-14 A & 384.60 & $08-02-93$ & -10.2 & 41.7 & 0.3 & -98.6 & -13.8 \\
\hline $\mathrm{UZ}-14 \mathrm{~A} 2$ & 384.60 & 08-02-93 & -10.1 & 40.6 & 3.1 & -97.5 & -13.5 \\
\hline $\mathrm{UZ}-14 \mathrm{~B}$ & 387.68 & $08-03-93$ & -9.5 & 36.6 & 0.0 & -97.1 & -13.4 \\
\hline $\mathrm{UZ}-14 \mathrm{C}$ & 390.75 & $08-05-93$ & -9.2 & 66.8 & 0.4 & -87.4 & -12.1 \\
\hline UZ-14 PT-1 & 390.75 & $08-17-93$ & -9.8 & 32.3 & 1.8 & -97.8 & -13.3 \\
\hline $\mathrm{UZ}-14 \mathrm{PT}-2$ & 390.75 & $08-19-93$ & $\ldots$ & 28.9 & 3.1 & -97.9 & -13.4 \\
\hline UZ-14 PT-4 & 390.75 & $08-27-93$ & -9.6 & 27.2 & 0.0 & -97.3 & -13.4 \\
\hline UZ-14 D & 390.75 & $08-31--93$ & -11.3 & 29.2 & 0.0 & -97.6 & -13.1 \\
\hline NRG-7a & 460.25 & $03-07-94$ & -16.6 & 66.9 & 10.4 & -93.9 & -12.8 \\
\hline
\end{tabular}

Perched-water $\delta^{13} \mathrm{C}$ values range from -9.2 to $-14.4 \%$ (except NRG-7a, which is $-16.6 \%$ ), which indicates older caliche was dissolved into the ground water, making water ages look older than their actual ages. For NRG-7a perched water, because the ${ }^{13} \mathrm{C}$ value is $-16.6 \%$, it implies that gas-liquid exchange might have occurred after caliche dissolution, causing the apparent age to look younger than its real age. If age corrections are applied to account for dilution by the older caliche and gas-liquid exchange after caliche dissolution, the implied perched-water residence times will probably be in the range of 2,000 to 7,000 years. Further investigations for ${ }^{14} \mathrm{C}$-age corrections will be made using geochemical model "NETPATH" in the near future. Since $\delta^{13} \mathrm{C}$ values for perched waters are very consistent, and their large water volumes were presumably little affected by the gas-water exchanges, relative ${ }^{14} \mathrm{C}$ residence times within the perched-water samples can be compared without correction.
Stable isotopic data (oxygen-18 and deuterium) are plotted as $\delta^{18} \mathrm{O}$ relative to $\delta \mathrm{D}$ in figure 16 . Perched-water values are slightly heavier than the saturated-zone values and generally are closer to the Yucca Mountain precipitation line, indicating little evaporation before infiltration (Craig, 1961; Dansgaard, 1964). Moreover, it can be seen that $\delta^{18} \mathrm{O}$ and $\delta \mathrm{D}$ values in table 7 for USW SD-7 pumping tests (from March 16 through 21) are fairly constant. If mixing of older waters (more than 10,000 years old, last ice age) is involved, stable $\delta^{18} \mathrm{O}$ and $\delta \mathrm{D}$ isotopic values will be significantly more negative than $-15 \%$ for $\delta^{18} \mathrm{O}$ and $-105 \%$ for $\delta \mathrm{D}$ [last ice age $\delta^{18} \mathrm{O}$ value is about -15 to $-20 \%$, and between -115 to $-120 \%$ for $\delta D$ (I.C. Yang, U.S. Geological Survey, unpub. data, 1996)]. All perched-water stable-isotopic values shown in table 7 are between -12.8 and $-13.8 \%$ for $\delta^{18} \mathrm{O}$ and -94 and $-99.8 \%$ for $\delta \mathrm{D}$. These values are consistent with a ${ }^{14} \mathrm{C}$ residence time of less than 7,000 years for the perched waters. 


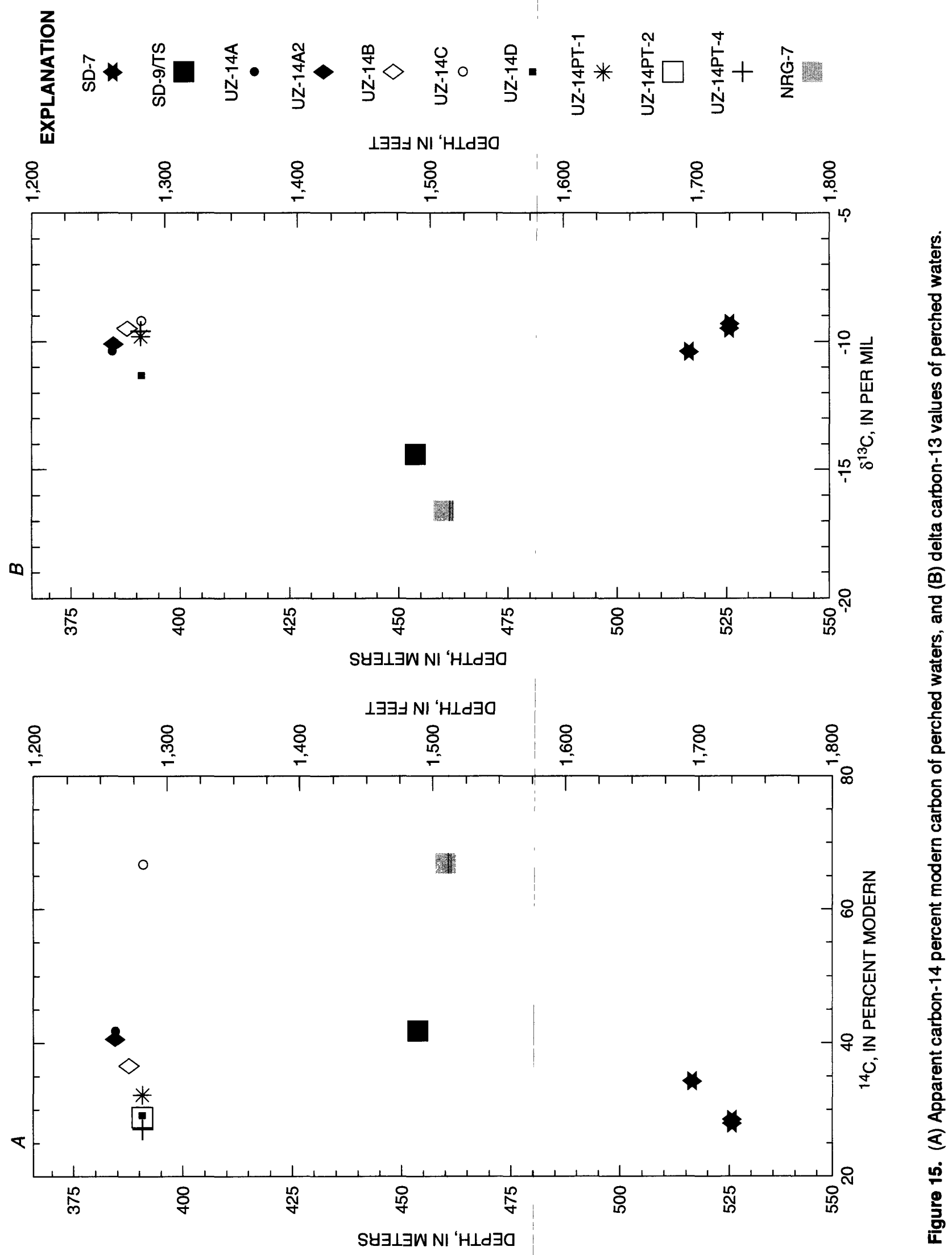




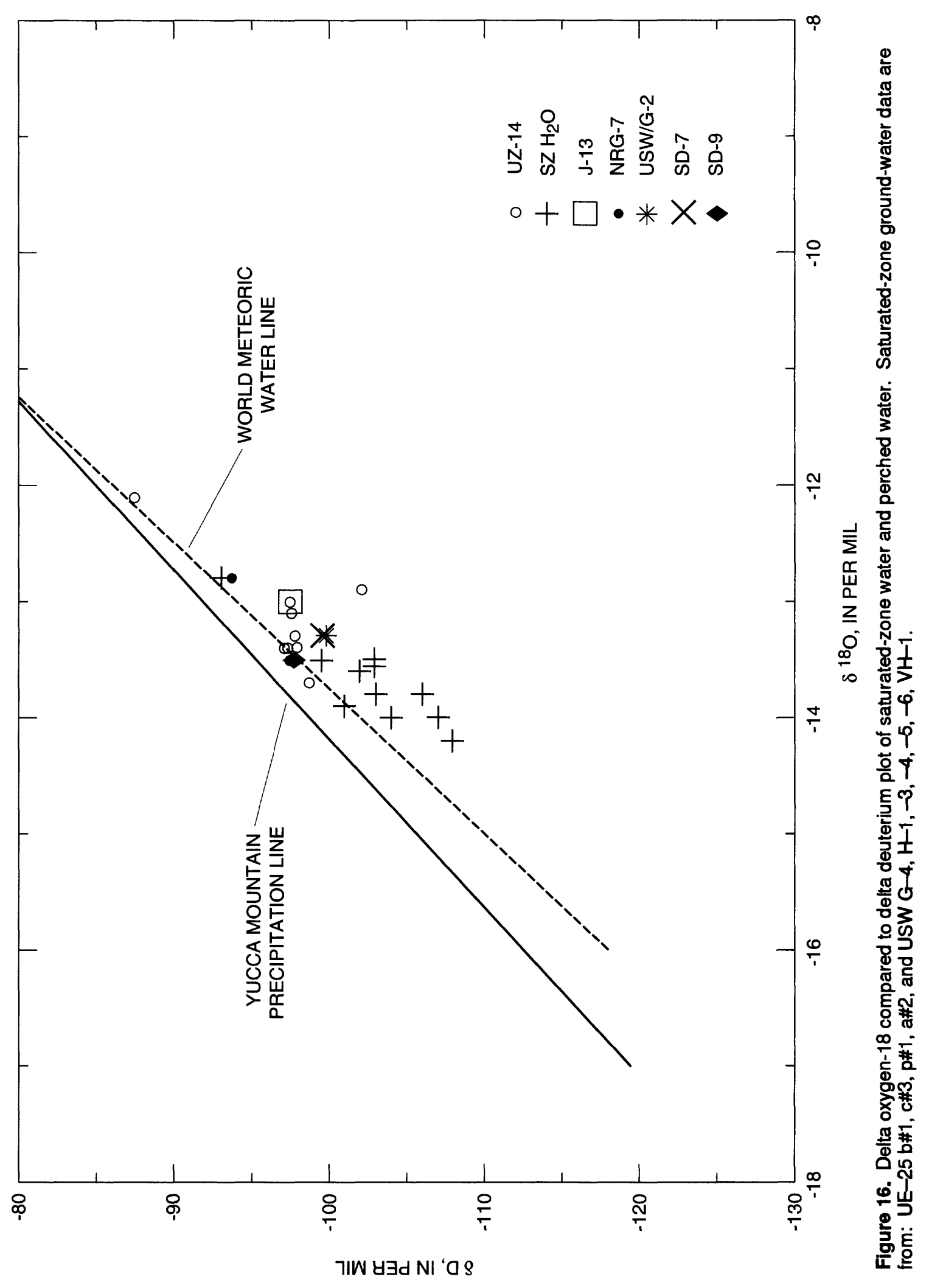


Gaseous-Phase Data from Borehole USW UZ-1

Gas sampling at USW UZ-1 is ongoing (1995). The data in this report are those collected from 1983 through 1994. Data from 1983 through mid-1985 and from 1988 to 1991 were published by Yang and others $(1985,1993)$. From 1983 through 1987 , gas samples from each probe were collected twice a year. It was several years before sample composition stabilized in the borehole. Once stabilized, sample collections were reduced to once a year (since 1988). (Gaseous-phase chemical and isotopic data for 1983-88 were collected prior to implementation of the approved U.S. Geological Survey Yucca Mountain Project quality-assurance program and, therefore, the data are not qualified. However, the data collected from 1989-94 are qualified.)

\section{Dry-Gas Composition}

When USW UZ-1 drilling was completed, the borehole was evacuated for a few hours before stemming and instrumentation. No $\mathrm{SF}_{6}$ concentration check was undertaken at that time. During all subsequent sampling, each probe was pumped at a rate of 250 to $500 \mathrm{~mL}$ per minute continuously for about 10 days. As shown in figure $17, \mathrm{SF}_{6}$ concentrations measured in 1984 were generally about $0.15 \mathrm{ppmv}$ except for large values near the surface and small values of about 0.09 and $0.1 \mathrm{ppmv}$ at $189 \mathrm{~m}$ and $228 \mathrm{~m}$. The probes above $45 \mathrm{~m}$ have concentrations of 0.3 to $0.45 \mathrm{ppmv}$. Since 1988 , the $\mathrm{SF}_{6}$ concentration has decreased steadily to less than 0.15 ppmv in all but the 1989 measurements. The reason for the large values in 1989 is unknown. In general, the drilling air appears to have been removed by $1986-87$, and data collected since that time should be representative of the rock-gas composition.

Results of gas chromatographic analysis on gas composition (April 1984, September 1986, and July 1994) of USW UZ-1 samples are shown in table 8. The gas composition is similar to atmospheric air, with slightly more $\mathrm{CO}_{2}$.

\section{Carbon-Dioxide $\left(\mathrm{CO}_{2}\right)$ Concentrations}

As shown in figures $18 \mathrm{~A}$ and $18 \mathrm{~B}, \mathrm{CO}_{2}$ concentrations are rather large (greater than 0.15 percent) at shallow depths (probes 1,2,3, and 4) and near the bottom (probe \#15) relative to others in the profiles (less than 0.15 percent). The larger concentrations at the shallow depths (more than 0.3 percent by volume) are also larger than other environments near and around Yucca Mountain (Thorstenson and others, 1990). This is attributed to the biologically produced $\mathrm{CO}_{2}$ from burial of vegetation during construction of the USW UZ-1 drilling pad. The larger $\mathrm{CO}_{2}$ concentrations at the bottom probe may be attributed to the breakdown of organic polymers from the drilling-fluid contamination. The $\mathrm{CO}_{2}$-concentration profiles as a function of time (fig. $18 \mathrm{~A}$ ) indicate that low $\mathrm{CO}_{2}$ concentrations were measured in 1983 and that, except for probe 13, concentrations steadily increased until 1987. The atmospheric $\mathrm{CO}_{2}$ concentration ( 0.034 percent) is significantly lower than most of the soil $\mathrm{CO}_{2}$ concentration in USW UZ-1. Thus, the early $\mathrm{CO}_{2}$ samples, diluted by drilling air in the borehole, showed relatively low $\mathrm{CO}_{2}$ concentrations. As the semiannual gassampling process proceeded, more drilling air was removed from the borehole and the pristine rock-gas composition was revealed. From 1988 through 1994, the $\mathrm{CO}_{2}$ concentration from 100 to $360 \mathrm{~m}$ showed little change (fig. 18B). The invariant $\mathrm{CO}_{2}$ concentrations at probe 13 are puzzling. This probe yielded the lowest amount of $\mathrm{CO}_{2}$ gas for 10 days of pumping.

\section{Delta Carbon-13 Value}

Delta carbon-13 values, relative to depth (fig. 19A) showed large variations in 1984 and 1985. As was explained previously concerning the $\mathrm{CO}_{2}$ concentration, the 1984 shift was the result of the drillingair contamination in the borehole. The $\delta^{13} \mathrm{C}$ value of the atmospheric $\mathrm{CO}_{2}$ at Yucca Mountain is about $-8.5 \%$ (Thorstenson and others, 1990, 1995). The presence of atmospheric air in collected samples would thus lead to larger $\delta^{13} \mathrm{C}$ values. Between 1986 and 1987 (fig. 19A), and 1988 through 1994 (fig. 19B), all $\delta^{13} \mathrm{C}$ values were fairly constant, ranging from -18 to $-23 \%$ o except for probes 9 and 10 in 1992 and near the bottom of the borehole (probes 13 and 14), where occasional departures from the average value were observed. 


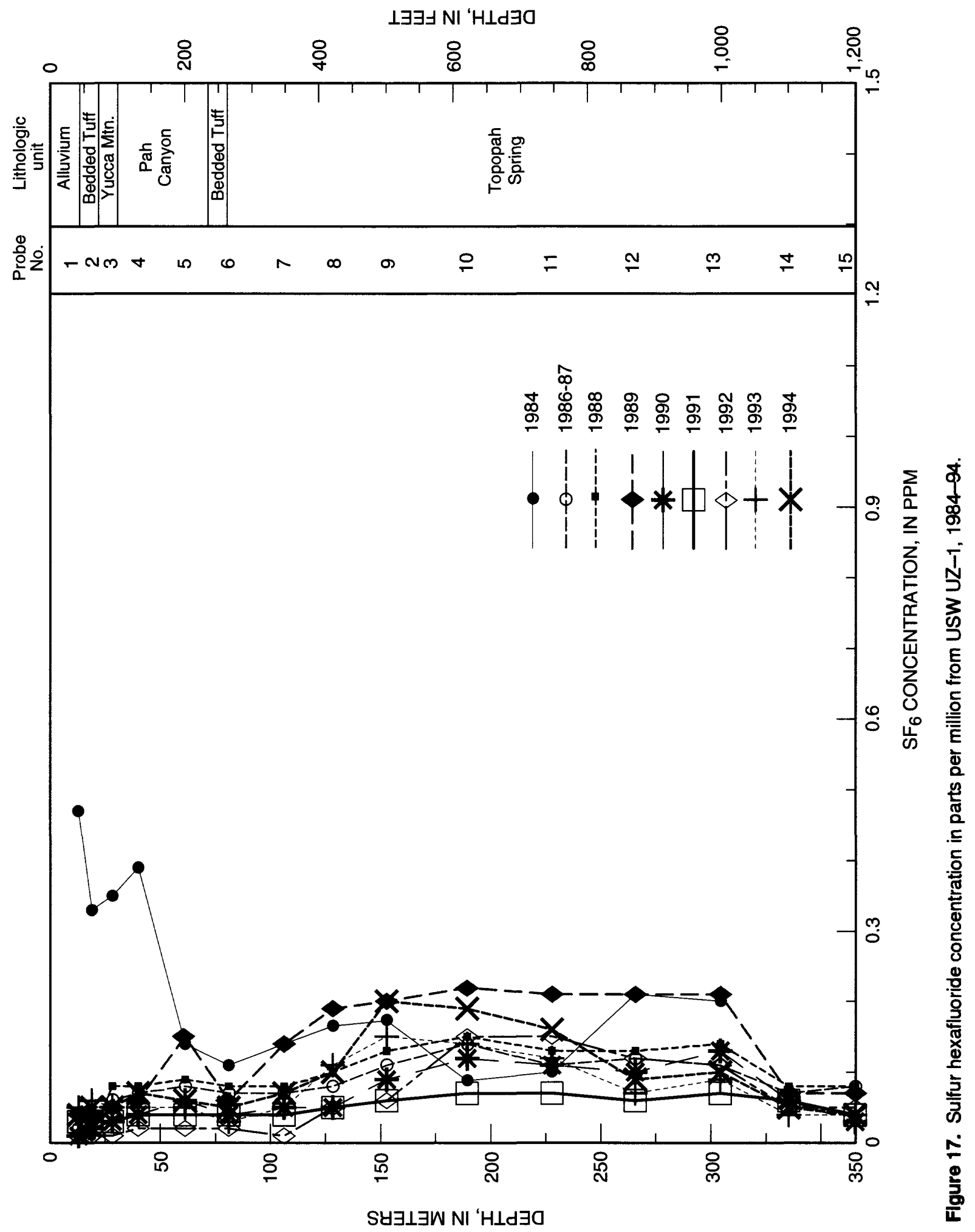


Table 8. USW UZ-1 dry-gas composition (percent by volume)

[- - , data not available $]$

\begin{tabular}{|c|c|c|c|c|c|}
\hline \multirow[b]{2}{*}{$\begin{array}{c}\text { Probe } \\
\text { no. }\end{array}$} & \multirow[b]{2}{*}{$\begin{array}{c}\text { Depth } \\
\text { (meters) }\end{array}$} & \multicolumn{4}{|c|}{ April 1984} \\
\hline & & $\begin{array}{c}\text { Nitrogen } \\
\mathbf{N}_{2}\end{array}$ & $\begin{array}{c}\text { Oxygen } \\
\mathrm{O}_{2}\end{array}$ & $\begin{array}{c}\text { Argon } \\
\text { Ar }\end{array}$ & $\begin{array}{c}\text { Carbon } \\
\text { dioxide } \\
\mathrm{CO}_{2}\end{array}$ \\
\hline 2 & 18.9 & 79.7 & 19.3 & 1.01 & 0.02 \\
\hline 3 & 28.3 & 79.2 & 19.8 & 1.01 & 0.03 \\
\hline 4 & 39.9 & 79.1 & 20.1 & 0.90 & 0.03 \\
\hline 6 & 81.1 & 78.4 & 20.5 & 0.98 & 0.08 \\
\hline 7 & 106.1 & 78.4 & 20.6 & 0.95 & 0.07 \\
\hline 8 & 128.3 & 78.4 & 20.5 & 1.01 & 0.09 \\
\hline 9 & 152.7 & 78.4 & 20.6 & 0.96 & 0.05 \\
\hline 10 & 189.3 & 78.6 & 20.4 & 0.96 & 0.04 \\
\hline 14 & 335.3 & $\cdots$ & $\cdots$ & $\cdots$ & $\cdots$ \\
\hline 15 & 367.9 & $\ldots$ & $\cdots$ & $\cdots$ & $\ldots$ \\
\hline
\end{tabular}

\begin{tabular}{|c|c|c|c|c|c|c|c|}
\hline \multirow[b]{2}{*}{$\begin{array}{c}\text { Probe } \\
\text { no. }\end{array}$} & \multicolumn{4}{|c|}{ September 1986} & \multicolumn{3}{|c|}{ July 1994} \\
\hline & $\begin{array}{c}\text { Nitrogen } \\
\mathrm{N}_{2}\end{array}$ & $\begin{array}{c}\text { Oxygen } \\
\mathrm{O}_{2}\end{array}$ & $\begin{array}{c}\text { Argon } \\
\text { Ar }\end{array}$ & $\begin{array}{c}\text { Carbon } \\
\text { dloxide } \\
\mathrm{CO}_{2}\end{array}$ & $\begin{array}{c}\text { Nitrogen } \\
\mathrm{N}_{2}\end{array}$ & $\begin{array}{c}\text { Oxygen } \\
\mathrm{O}_{2}\end{array}$ & $\begin{array}{c}\text { Carbon } \\
\text { dioxide } \\
\mathrm{CO}_{2}\end{array}$ \\
\hline 1 & 78.4 & 19.4 & $0 . \overline{97}$ & 1.30 & 78.2 & 20.8 & 0.79 \\
\hline 2 & 79.0 & 19.7 & 0.98 & 0.39 & 77.8 & 20.6 & 0.53 \\
\hline 3 & 79.1 & 19.9 & 0.99 & 0.05 & 77.1 & 20.4 & 0.22 \\
\hline 4 & -- & $\ldots$ & $\ldots$ & $\ldots$ & 77.1 & 20.4 & 0.41 \\
\hline 5 & $\cdots$ & $\cdots$ & $\cdots$ & $\cdots$ & 77.7 & 20.4 & 0.23 \\
\hline 6 & $\cdots$ & $\cdots$ & $\ldots$ & $\ldots$ & 78.5 & 20.8 & 0.20 \\
\hline 7 & 78.4 & 20.6 & 0.97 & 0.10 & 78.1 & 20.8 & 0.11 \\
\hline 8 & $\ldots$ & $\ldots$ & $\ldots$ & $\cdots$ & 77.9 & 20.8 & 0.10 \\
\hline 9 & $\ldots$ & $\ldots$ & $\ldots$ & $\ldots$ & 78.0 & 20.8 & 0.08 \\
\hline 10 & - - & $\ldots$ & $\ldots$ & $\ldots$ & 77.7 & 20.6 & 0.08 \\
\hline 11 & $\cdots$ & $\ldots$ & $\ldots$ & $\ldots$ & 77.4 & 20.4 & 0.11 \\
\hline 12 & $\ldots$ & $\ldots$ & $\ldots$ & $\ldots$ & 76.7 & 20.5 & 0.11 \\
\hline 13 & 78.5 & 20.6 & 0.96 & 0.02 & 76.9 & 20.5 & 0.05 \\
\hline 14 & 78.6 & 20.4 & 0.97 & 0.07 & 78.1 & 20.9 & 0.13 \\
\hline 15 & 80.3 & 18.5 & 0.99 & 0.26 & 78.1 & 20.6 & 0.36 \\
\hline
\end{tabular}

The $\delta^{13} \mathrm{C}$ value of about $-20 \%$ at shallow depths is representative of biogenic $\mathrm{CO}_{2}\left(\mathrm{CO}_{2}\right.$ gas respired from plant roots). The average $\delta^{13} \mathrm{C}$ value of near $-20 \%$ at all depths indicates that the $\mathrm{CO}_{2}$ gas in the $\mathrm{UZ}$ has not exchanged with or is in equilibrium with in-situ calcite or caliche because the solid fracturefilling carbonates have a $\delta^{13} \mathrm{C}$ value generally between -9 and $-3 \%$ in the UZ (Szabo and Kyser, 1985;
Whelan and Stuckless, 1992). If exchange had occurred, the $\mathrm{CO}_{2}$ gas $\delta^{13} \mathrm{C}$ values would have become larger, which was not observed (fig. 19B). Also, the ${ }^{14} \mathrm{C}$ age of the $\mathrm{CO}_{2}$ gas would be older than its real age because of the old ${ }^{14} \mathrm{C}$ age of calcite and caliche [greater than 20,000 years to as much as several hundred thousand years (Szabo and Kyser, 1985; Whelan and others, 1994)]. 

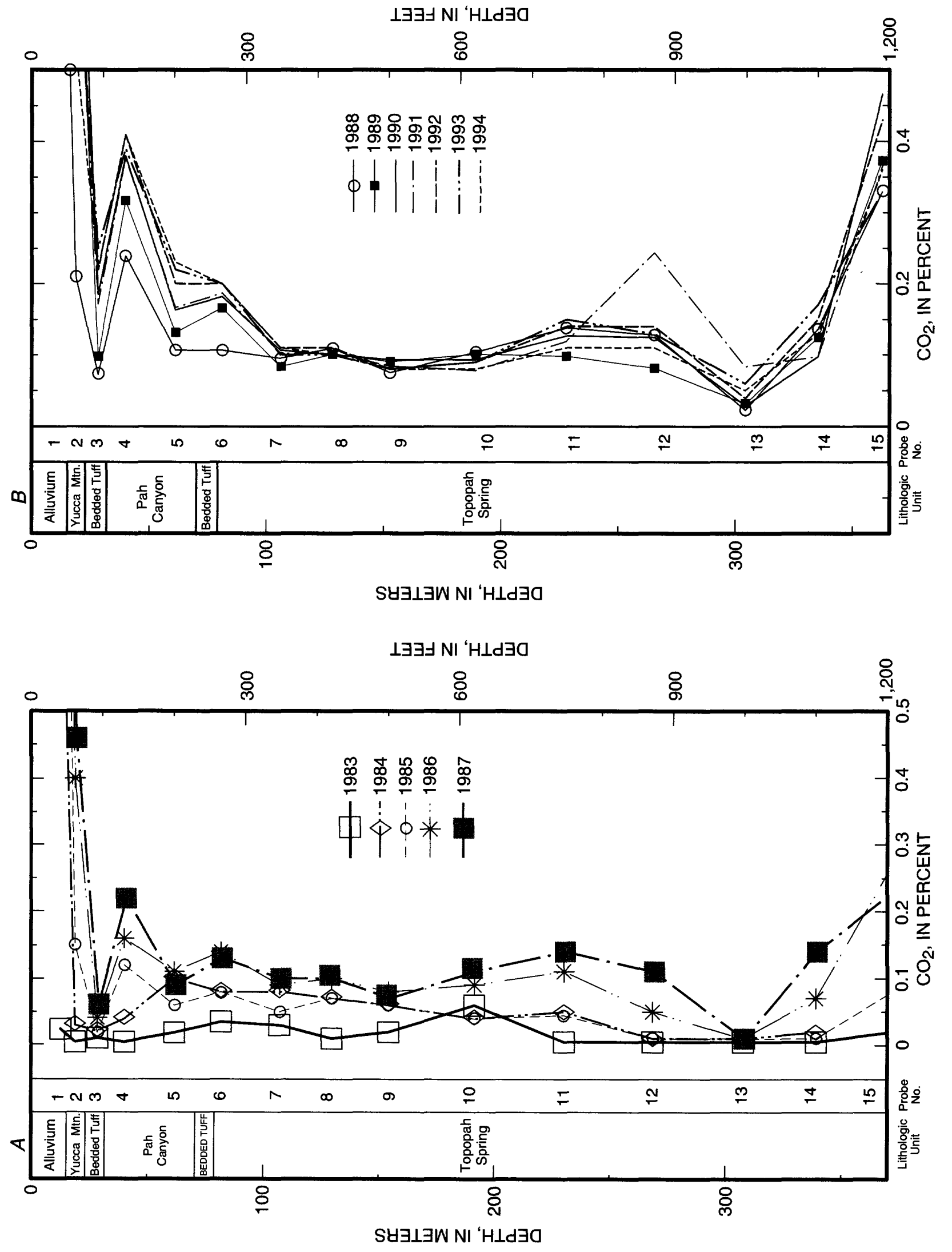

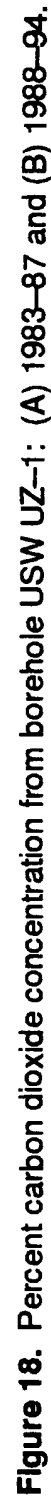




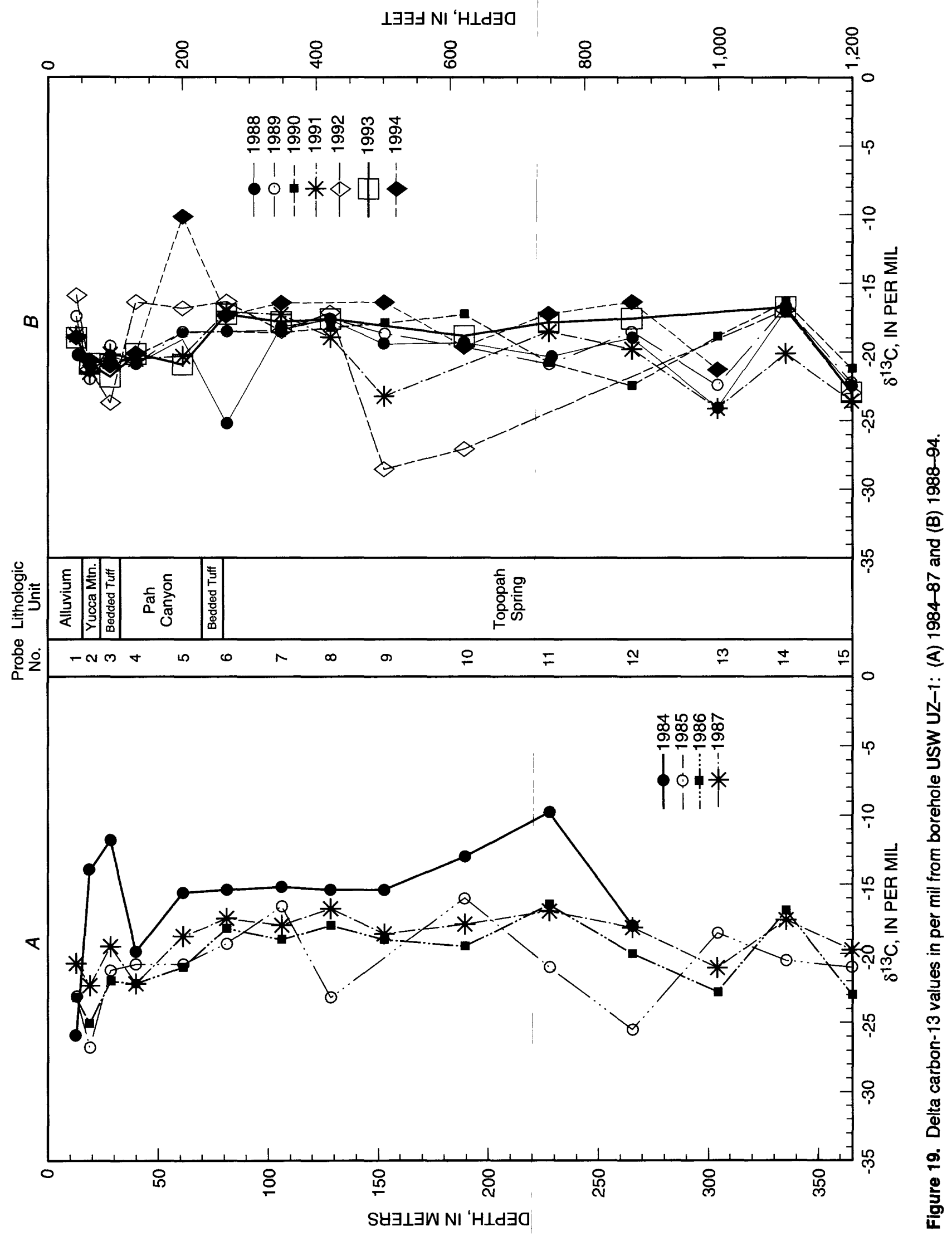


On the other hand, the extent of interactions between the gaseous-phase $\mathrm{CO}_{2}$ and the pore-water bicarbonate can be seen from the following data analysis. The concentration of dissolved $\mathrm{CO}_{2}$, as bicarbonate, analyzed from pore water of UZ boreholes has values ranging from $30 \mathrm{mg} / \mathrm{L}$ at shallow depth to about $250 \mathrm{mg} / \mathrm{L}$ at a depth of about $500 \mathrm{~m}$ with some exceptions. These bicarbonate concentrations are equivalent to 0.5-4.0 millimoles per liter $(\mathrm{mmol} / \mathrm{L})$. Volumetrically, the pore-water volume to the pore-air volume can be estimated as follows. According to Montazer and Wilson (1984), saturation in the Yucca Mountain cores ranges from 60 percent in the Paintbrush Tuff to 90 percent in the Calico Hills Formation. Therefore, the volume ratio of pore water to pore air will range from $(60 / 40=) 1.5$ to $(90 / 10=) 9$. The concentration of $\mathrm{CO}_{2}$ in pore air is about 0.1 percent (fig. $18 \mathrm{~B}$ ). Thus, the amount of $\mathrm{CO}_{2}$ in a liter of pore air at $25^{\circ} \mathrm{C}$ and one atmosphere is (11) $\times(0.001) /(241 / \mathrm{mole})=0.00004 \mathrm{~mol}$ or $0.04 \mathrm{mmol}$. Since pore-water volume is about 1.5 to 9 times greater than the pore air, the amount of carbon in an aqueousphase reservoir relative to carbon in the $\mathrm{CO}_{2}$ gaseousphase reservoir is about $\{[(0.5+4.0) / 2] \times 1.5 / 0.04\}=84$ to $\{[(0.5+4.0) / 2] \times 9 / 0.04=\} 506$ times greater. Therefore, most carbon present in the underground UZ is in the aqueous phase. Consequently, an aqueous phase will dominate the gaseous phase if any exchange occurs. Preliminary $\delta^{13} \mathrm{C}$ values for pore water from $\mathrm{UZ}$ cores ranged from -10 to $-25 \%$ (this report). If $\mathrm{CO}_{2}$ gas is in equilibrium with the pore-water bicarbonate, the equilibrium fractionation factor (Friedman and others, 1977) for the $\mathrm{CO}_{2}(\mathrm{~g})-\mathrm{HCO}_{3}$ (aq.) system predicts a $\delta^{13} \mathrm{C}$ value about $-8.5 \%$ lighter for $\mathrm{CO}_{2}(\mathrm{~g})$ relative to the $\delta^{13} \mathrm{C}$ value of bicarbonate in an aqueous phase. If so, $\delta^{13} \mathrm{C}$ values of $\mathrm{CO}_{2}$ gas in the borehole would be between $-18.5 \%$ and $-33.5 \%$, which is not always the case in figure 19B. The $\mathrm{CO}_{2}$-gas ${ }^{14} \mathrm{C}$ values are also not in equilibrium with the aqueous-phase ${ }^{14} \mathrm{C}$ values, as mentioned previously (figs. 11 and 13A). Drilling air in the borehole of USW UZ-1 in 1984 through 1987 may have an effect on this disequilibrium between gaseous and pore-water phases. Furthermore, many open boreholes are known to inhale or exhale throughout the year. This could also affect the disequilibrium. However, the fact that the ${ }^{14} \mathrm{C}$ values of rock gas are decreasing steadily with depth infers little effect by inhalation or exhalation (if topographic effect is significant, ${ }^{14} \mathrm{C}$ values will scatter instead of steadily decreasing). The nonequilibrium condition in a $\mathrm{CO}_{2}(\mathrm{~g})-\mathrm{HCO}_{3}$ (aq.) system could be due to the fact that gas samples were collected mainly from dry fractures with little contribution from pore gas, which is in equilibrium with pore water. Thus, interactions between pore gas and pore water are not detected. Thorstenson and others (1990) also observed that approximately $2 \times 10^{6} \mathrm{~m}^{3}$ of gas was exhausted by USW UZ-6s borehole without compositional changes in rock gas. If the gas $\mathrm{CO}_{2}$ was interacting with a large aqueous-phase carbon reservoir, a gas-phase $\mathrm{CO}_{2}$ concentration would be modified, which was not observed. It is conceivable that such nonequilibrium conditions exist between gaseous and aqueous phases in many parts of Yucca Mountain. Due to insufficient gaseous-phase data and knowledge of the fractured system at the mountain, this statement is preliminary.

\section{Carbon-14 Data}

The ${ }^{14} \mathrm{C}$ data plotted in figure $20 \mathrm{~A}$ also indicate large variations in 1984 and 1985 . The values tend to lie on the right-hand side of the 1986 values (that is, higher ${ }^{14} \mathrm{C}$ activity values). This is consistent with the previous explanation of the drilling-air contamination in the borehole. Presentday ${ }^{14} \mathrm{C}$ activity in the atmospheric air is about $120 \mathrm{pmc}$, which would cause the ${ }^{14} \mathrm{C}$ activity of soil $\mathrm{CO}_{2}$ gas to shift toward higher values. After pumping for 2 years, the ${ }^{14} \mathrm{C}$ data are very consistent for the last 7 years (fig. 20B), with a gradual decrease in ${ }^{14} \mathrm{C}$ activity with depth to about 23 pmc at $368 \mathrm{~m}$.

The ${ }^{14} \mathrm{C}$ profile in figure $20 \mathrm{~B}$ shows that there is an abrupt change in the slope at probe 5. The transport velocity $\left({ }^{14} \mathrm{C}\right.$ concentration gradient over distance) between probes 1 and 5 is smaller than the transport velocity between probes 5 and 15 . The smaller transport velocity may be due to higher porosity and moisture content in this zone. An estimate of the traveltime in the Topopah Spring Tuff (between probes 5 and 15) based on the apparent ${ }^{14} \mathrm{C}$ ages and the distance yields gas movement of $3.26 \mathrm{~cm} / \mathrm{yr}$. This is a minimum value because the distance used for the calculation is simply depth in the borehole.

A gas-diffusion effect would cause ${ }^{12} \mathrm{CO}_{2}$ to diffuse downward faster than the heavier ${ }^{14} \mathrm{CO}_{2}$ molecules and would result in an older ${ }^{14} \mathrm{C}$ age at a greater depth than if the ${ }^{14} \mathrm{C}$ decay alone were considered. However, the effect is small and can be neglected. 

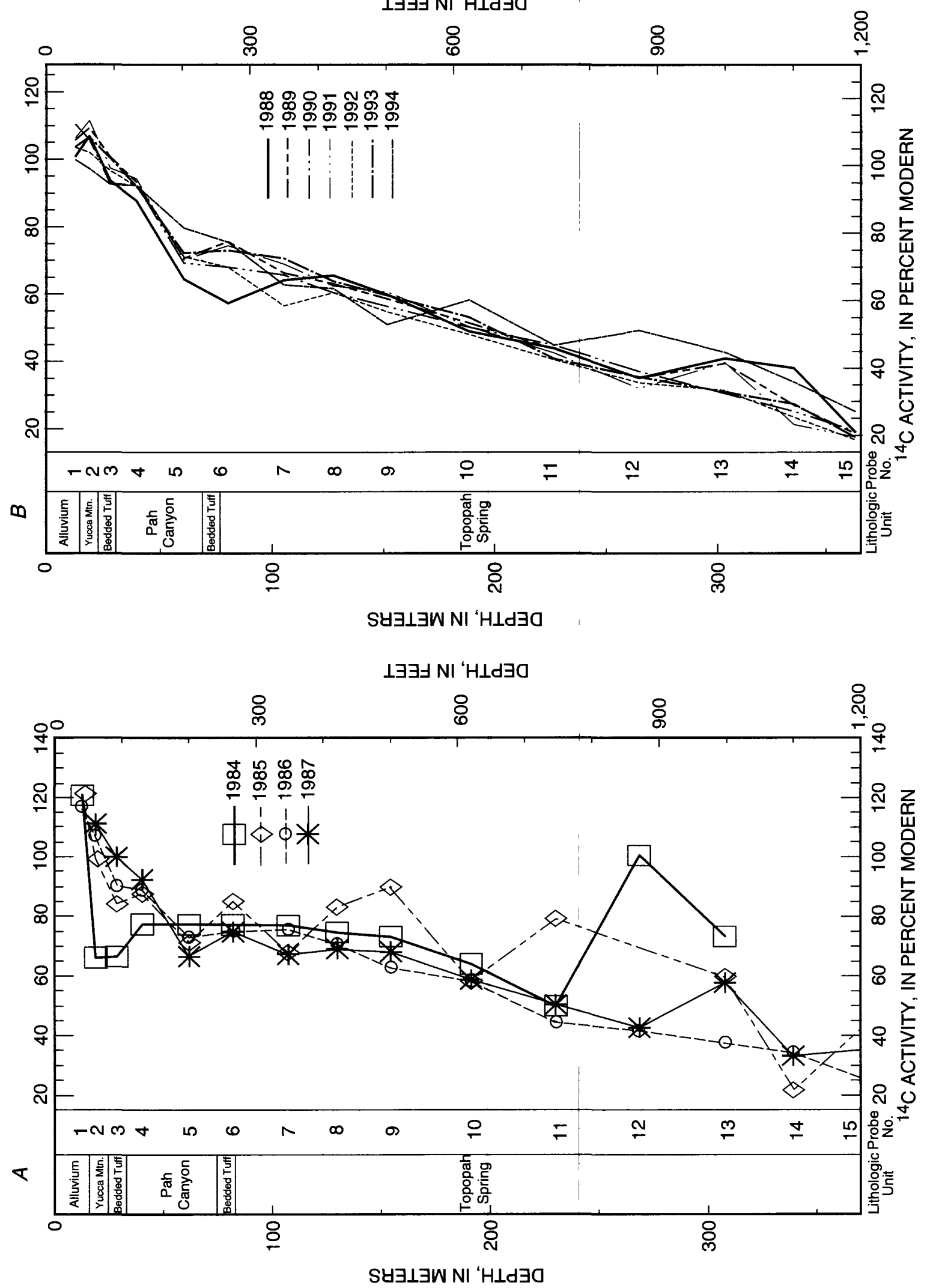


\section{Gaseous-Phase Data from Selected Open Boreholes}

Dry-gas composition was measured in the instrumented borehole of UZ-1. Since the gas composition was essentially the same as the atmospheric air composition, no attempt was made to repeat the measurement. Carbon dioxide and carbon isotopic data were measured in selected open boreholes (NRG-6, NRG-7a, UZ\#16, and SD-12) and are given in table 9. As can be seen from the table, $\delta^{13} \mathrm{C}$ values are heavier, in many cases, than the values for UZ-1. Also, ${ }^{14} \mathrm{C}$ values do not show a steady decrease with depths, as seen in UZ-1. The reason for the heavier $\delta^{13} \mathrm{C}$ values and younger ${ }^{14} \mathrm{C}$ values at depths could be due to contamination with atmospheric air as a result of a leaking packer or incomplete removal of drilling air. It has been observed in many locations at Yucca Mountain that topographic effects cause the gas to inhale or exhale through the open boreholes. This will also result in possible contamination of formation gas by air. In one case at the Prow Pass zone in UE-25 UZ\#16 where the air-K test packer system was used, the rock-gas ${ }^{14} \mathrm{C}$ age is about $\mathrm{I} 0,000$ years, similar to the gas age obtained from the deepest probe in USW UZ-1, an instrumented borehole. This could be due to the packer used in this zone having a tight seal, or alternatively gas inhalation or exhalation in the borehole does not reach to this depth. The $\delta^{13} \mathrm{C}$ value of $-18.4 \%$ strongly supports this argument. We have not collected any gas data from NRG -6 and NRG -7 a boreholes because instrument tests are still in progress. The long-term carbon isotopic data (more than I0 years' data) from USW UZ-1, which show steady decrease in ${ }^{14} \mathrm{C}$ ages as a function of depth with consistent $\delta^{13} \mathrm{C}$ values, are the only dependable rock-gas data so far in the Topopah Spring unit and below.

\section{MODEL CALCULATIONS}

A gas-diffusion and two aqueous-flow models were applied to explain the observed gaseous ${ }^{14} \mathrm{C}$ distributions in USW UZ-1 and tritium concentrations in pore-water samples of UE-25 UZ\#16.

The gas-diffusion model: A steady-state diffusion of ${ }^{14} \mathrm{CO}_{2}$ from a constant source at the surface with firstorder radioactive decay was considered. In this case, the finite depth of the UZ must be taken into account because of the length of times possibly available for diffusion. The equation for steady-state diffusion and first-order homogeneous reaction in a finite layer is taken from Bird and others $(1960$, p. 533 , eq. 17.4-7). The equation assumes that the reactant and product species are present in very small concentrations and that the net gas flux is zero. Thus, multicomponent effects (Thorstenson and others, 1989) and advective transport due to local topographic effects (Weeks, 1987) are not considered.

The aqueous-flow model: Piston-flow and wellmixed models were used to determine if observed tritium concentrations are feasible, given estimated tritium input functions for the Yucca Mountain site. Numerous studies of surface- and ground-water ages and mixing rates have been conducted over the years with the use of tritium (Carmi and Gat, 1973; Pearson and Truesdell, 1978; Simpson and Carmi, 1983; Egboka and others, 1983; Knott and Olimpio, 1986; Vuataz and Goff, 1986; and Shevenell, 1991). Discussions of piston-flow compared to well-mixed flow behavior have been abundant in these and other studies. Simpson and Carmi (1983) focused on a simple exponential model of piston flow while studies by $\mathrm{Nir}$ (1964) discussed the concepts of well-mixed and piston-flow reservoirs, utilizing hydrodynamic dispersion coefficients in describing the well-mixed endmember. Carmi and others (1973) simulated wellmixed behavior with the use of an age function that incorporates a recharge weighting function to determine ages from the combination of tritium input over a given number of years. Pearson and Truesdell (1978) and SheveneIl (1991) applied this model to the geothermal systems.

\section{Gas-Transport Model}

To a first approximation, the $\delta^{13} \mathrm{C}$ data suggest that there is no systematic $\mathrm{CO}_{2}$ reaction with solid carbonate in the USW UZ-I borehole. Thus, the possibility must be considered that the gas in the borehole is stagnant and that the decrease of ${ }^{14} \mathrm{C}$ with depth is due to radioactive decay and that the ${ }^{14} \mathrm{C}$ data thus imply substantial "ages" of the $\mathrm{CO}_{2}$ at depth.

The $\mathrm{CO}_{2}$ concentrations in the upper few probes (probes I through 4, figs. 18A and 18B) are anomalously high relative to concentrations observed in other environments at the NTS (Thorstenson and others, I990). The UZ-1 data also suggest that these high concentrations are migrating downward with time (fig. I8). It is likely that construction of the UZ-I drill pad caused some effects on these $\mathrm{CO}_{2}$ concentrations, for example, through burial of vegetation during construction. Consequently, gas ${ }^{14} \mathrm{C}$ data from the upper few probes will not be considered here. 
Table 9. Carbon-14 $\left({ }^{14} \mathrm{C}\right)$ and delta carbon-13 (gas) data from boreholes NRG-6, NRG-7a, UZ-16, and SD-12

[- - -, data not analyzed; pmc, percent modern carbon; \%o, parts per thousand; PDB, Pee Dee Belemnite standard]

\begin{tabular}{|c|c|c|c|c|c|c|}
\hline Borehole & $\begin{array}{l}\text { Depth } \\
\text { (meters) }\end{array}$ & $\begin{array}{l}\text { Lithologic } \\
\text { unit }\end{array}$ & $\begin{array}{c}\text { Carbon } \\
\text { dioxide } \\
\left(\mathrm{CO}_{2}\right)\end{array}$ & $\begin{array}{c}{ }^{14} \mathrm{C} \\
\text { (pmc) }\end{array}$ & $\begin{array}{c}{ }^{13} \mathrm{C} /{ }^{12} \mathrm{C} \\
(\%, \mathrm{PDB})\end{array}$ & $\begin{array}{l}\text { leotopic } \\
\text { analytical } \\
\text { laboratony }\end{array}$ \\
\hline NRG-6 & 6.1 & Tiva Canyon & 0.07 & $\cdots$ & -12.83 & USGS stable isotope \\
\hline NRG -6 & 6.1 & Tiva Canyon & & $\cdots$ & -15.18 & USGS stable isotope \\
\hline NRG 6 & 6.1 & Tiva Canyon & & $\ldots$ & -15.15 & USGS stable isotope \\
\hline NRG -6 & 24.4 & Tiva Canyon & 0.11 & & -14.25 & USGS stable isotope \\
\hline NRG 6 & 24.4 & Tiva Canyon & & 92.1 & -15.2 & Geochron \\
\hline NRG 6 & $26.8-38.1$ & Tiva Canyon & 0.07 & $\ldots$ & -14.60 & USGS stable isotope \\
\hline NRG-6 & $26.8-38.1$ & Tiva Canyon & & 61.0 & -13.9 & Geochron \\
\hline NRG -6 & $26.8-38.1$ & Tiva Canyon & & $\ldots$ & -14.62 & USGS stable isotope \\
\hline NRG-6 & $26.8-38.1$ & Tiva Canyon & & $\ldots$ & -14.61 & USGS stable isotope \\
\hline NRG -6 & $26.8-38.1$ & Tiva Canyon & & $\cdots$ & -14.63 & USGS stable isotope \\
\hline NRG -6 & $26.8-38.1$ & Tiva Canyon & & $\cdots$ & -14.99 & USGS stable isotope \\
\hline NRG -6 & $26.8-38.1$ & Tiva Canyon & 1 & $\cdots$ & -15.02 & USGS stable isotope \\
\hline NRG -6 & 61.0 & Pah Canyon & 0.10 & $\ldots$ & -14.14 & USGS stable isotope \\
\hline NRG -6 & 61.0 & Pah Canyon & & $\ldots$ & -14.24 & USGS stable isotope \\
\hline NRG -6 & 61.0 & Pah Canyon & & 91.0 & -14.9 & Geochron \\
\hline NRG -6 & 83.8 & Topopah Spring & 0.05 & $\ldots$ & -15.05 & USGS stable isotope \\
\hline NRG 6 & 83.8 & Topopah Spring & & $-\cdots$ & -15.05 & USGS stable isotope \\
\hline NRG -6 & 107 & Topopah Spring & & $\cdots$ & -17.24 & USGS stable isotope \\
\hline NRG 6 & 183 & Topopah Spring & 0.10 & 83.2 & -15.5 & Geochron \\
\hline NRG -6 & 183 & Topopah Spring & & $\cdots$ & -14.06 & USGS stable isotope \\
\hline NRG -6 & 221 & Topopah Spring & 0.07 & $\ldots$ & -14.69 & USGS stable isotope \\
\hline NRG 6 & 221 & Topopah Spring & & $-\ldots$ & -14.69 & USGS stable isotope \\
\hline NRG -6 & $233-238$ & Topopah Spring & & $\ldots$ & -10.14 & USGS stable isotope \\
\hline NRG 6 & $233-238$ & Topopah Spring & & $\cdots$ & -10.31 & USGS stable isotope \\
\hline NRG 6 & 282 & Topopah Spring & 0.11 & 94.2 & -16.1 & Geochron \\
\hline NRG -6 & 282 & Topopah Spring & & $\cdots$ & -14.14 & USGS stable isotope \\
\hline NRG -6 & 305 & Topopah Spring & 0.07 & $\ldots$ & -14.43 & USGS stable isotope \\
\hline NRG-6 & 305 & Topopah Spring & 1 & $\ldots$ & -14.34 & USGS stable isotope \\
\hline$N R G-7 a$ & 42.7 & Yucca Mountain & 0.12 & 108.0 & -16.8 & Geochron \\
\hline NRG $-7 \mathrm{a}$ & 42.7 & Yucca Mountain & & $\ldots$ & -17.24 & USGS stable isotope \\
\hline NRG $-7 a$ & 149 & Topopah Spring & 0.19 & $\ldots$ & -17.69 & USGS stable isotope \\
\hline NRG-7a & 149 & Topopah Spring & & $\ldots$ & -17.68 & USGS stable isotope \\
\hline$N R G-7 a$ & 149 & Topopah Spring & & 111.7 & -18.2 & Geochron \\
\hline$N R G-7 a$ & 271 & Topopah Spring & 0.15 & 111.0 & -19.0 & Geochron \\
\hline NRG-7a & 271 & Topopah Spring & & $\ldots$ & -17.75 & USGS stable isotope \\
\hline$N R G-7 a$ & 271 & Topopah Spring & & $\ldots$ & -17.73 & USGS stable isotope \\
\hline NRG-7a & 370 & Topopah Spring & 0.19 & $\cdots$ & -17.61 & USGS stable isotope \\
\hline$U Z-16$ & 45.7 & Tiva Canyon & & 73.2 & -15.5 & Geochron \\
\hline$U Z-16$ & 45.7 & Tiva Canyon & & $\ldots$ & -13.82 & USGS stable isotope \\
\hline$U Z-16$ & 45.7 & Tiva Canyon & & $\ldots$ & -13.72 & USGS stable isotope \\
\hline UZ-16 & $14.3-74.1$ & Tiva to Topopah & & 72.7 & -14.0 & Geochron \\
\hline UZ-16 & $14.3-74.1$ & Tiva to Topopah & & $-\cdots$ & -12.32 & USGS stable isotope \\
\hline UZ-16 & 73.1 & Topopah Spring & & $\ldots$ & -13.19 & USGS stable isotope \\
\hline $\mathrm{UZ}-16$ & 73.1 & Topopah Spring & & $\cdots$ & -13.14 & USGS stable isotope \\
\hline
\end{tabular}


Table 9. Carbon-14 $\left({ }^{14} \mathrm{C}\right)$ and delta carbon-13 (gas) data from boreholes NRG-6, NRG-7a, UZ-16, and SD-12-Continued [- - , data not analyzed; pmc, percent modern carbon; \%, parts per thousand; PDB, Pee Dee Belemnite standard]

\begin{tabular}{|c|c|c|c|c|c|c|}
\hline Borehole & $\begin{array}{c}\text { Depth } \\
\text { (meters) }\end{array}$ & $\begin{array}{l}\text { Lithologic } \\
\text { unit }\end{array}$ & $\begin{array}{l}\text { Carbon } \\
\text { dioxide } \\
\left(\mathrm{CO}_{2}\right) \\
\end{array}$ & $\begin{array}{c}{ }^{14} \mathrm{C} \\
(\mathrm{pmc})\end{array}$ & $\begin{array}{l}{ }^{13} \mathrm{C} /{ }^{12} \mathrm{C} \\
(\%, \text { PDB })\end{array}$ & $\begin{array}{l}\text { lsotoplc } \\
\text { analyticai } \\
\text { laboratory }\end{array}$ \\
\hline $\mathrm{UZ}-16$ & 82.3 & Topopah Spring & & $\cdots$ & -12.97 & USGS stable isotope \\
\hline $\mathrm{UZ}-16$ & 82.3 & Topopah Spring & & $\ldots$ & -12.94 & USGS stable isotope \\
\hline UZ-16 & $74.1-148$ & Topopah Spring & & 87.0 & -16.5 & Geochron \\
\hline $\mathrm{UZ}-16$ & $74.1-148$ & Topopah Spring & & ... & -19.71 & USGS stable isotope \\
\hline $\mathrm{UZ}-16$ & $74.1-148$ & Topopah Spring & & $\ldots$ & -20.07 & USGS stable isotope \\
\hline$U Z-16$ & $74.1-148$ & Topopah Spring & & $\ldots$ & -20.86 & USGS stable isotope \\
\hline UZ-16 & $148-163$ & Topopah Spring & & 81.6 & -14.7 & Geochron \\
\hline $\mathrm{UZ}-16$ & $148-163$ & Topopah Spring & & $\ldots$ & -18.31 & USGS stable isotope \\
\hline $\mathrm{UZ}-16$ & $163-512$ & Topopah Spring to Prow Pass & & 89.2 & -17.0 & Geochron \\
\hline $\mathrm{UZ}-16$ & $163-512$ & Topopah Spring to Prow Pass & & $\ldots$ & -15.63 & USGS stable isotope \\
\hline $\mathrm{UZ}-16$ & $477-481$ & Prow Pass & & $\ldots$ & -17.60 & USGS stable isotope \\
\hline $\mathrm{UZ}-16$ & $477-481$ & Prow Pass & & 25.8 & -18.4 & Geochron \\
\hline $\mathrm{UZ}-16$ & $477-481$ & Prow Pass & & $\ldots$ & -16.32 & USGS stable isotope \\
\hline$U Z-16$ & $477-481$ & Prow Pass & & $\ldots$ & -16.26 & USGS stable isotope \\
\hline$U Z-16$ & $477-481$ & Prow Pass & & $\ldots$ & -15.51 & USGS stable isotope \\
\hline SD-12 & $216-220$ & Topopah Spring & & 74.33 & -11.6 & Geochron \\
\hline SD-12 & $342-347$ & Topopah Spring & & 60.17 & -16.1 & Geochron \\
\hline
\end{tabular}

Surface ${ }^{14} \mathrm{CO}_{2}$ concentration is calculated with $\mathrm{CO}_{2}=0.125 \%$ and a ${ }^{14} \mathrm{CO}_{2}=100$ pmc. The steadystate diffusion of ${ }^{14} \mathrm{CO}_{2}$ from a constant source at the surface with first-order radioactive decay was considered by Thorstenson and others (U.S. Geological Survey administrative report, 1995). Calculations were made with a depth of $500 \mathrm{~m}$ for values of diffusivity ranging from $10^{-6}$ to $10^{-7} \mathrm{~m}^{2} / \mathrm{s}$. A good visual fit is obtained with $\mathrm{D}=10^{-6.7} \mathrm{~m}^{2} / \mathrm{s}\left(\mathrm{D}=2.0 \times 10^{-7} \mathrm{~m}^{2} / \mathrm{s}\right)$.

The calculated and observed concentrations of ${ }^{14} \mathrm{CO}_{2}$ are plotted in figure 21 . The calculations do not explicitly take into account solubility or reactions. While simple Fickian diffusion may not be the only process that is operative, it appears that it can account for the observed depth distribution of ${ }^{14} \mathrm{CO}_{2}$ in the fractured Topopah Spring. (This conclusion is supportable using solely the data that were collected in compliance with the approved U.S. Geological Survey Yucca Mountain Project quality-assurance program.) This is in marked contrast to the observations in the open boreholes at the Yucca Mountain crest, where it appears impossible to account for observations without major advection in the system (Weeks, 1987; Thorstenson and others, 1990).

\section{Use of Tritium in Ground Water to Determine Water Mean Residence Times}

Tritium generally behaves conservatively in the ground-water system. Therefore, its concentration in water is a reliable indicator of mixing and relative ground-water ages. The flow type is assumed to be either piston flow, well-mixed flow, or some combination of the two. The piston flow (no mixing between fluids of different ages) provides an upper limit, and the well-mixed model (complete mixing of fluids of different ages) provides the lower limit on mean residence times of ground water in the system.

\section{Piston-Flow, or Preferential-Flow, Model}

This flow model does not take into account hydrodynamic-dispersive mixing within the unsaturated-zone reservoir system, nor from other sources of water. Output tritium concentrations depend only on the input concentration at recharge and the elapsed time since the recharge. The relationship between input and output concentration is simply a standard decay equation:

$$
C_{\text {out }}(t)=C_{\text {in }}(t-T) e^{-\lambda \mathrm{T}}
$$




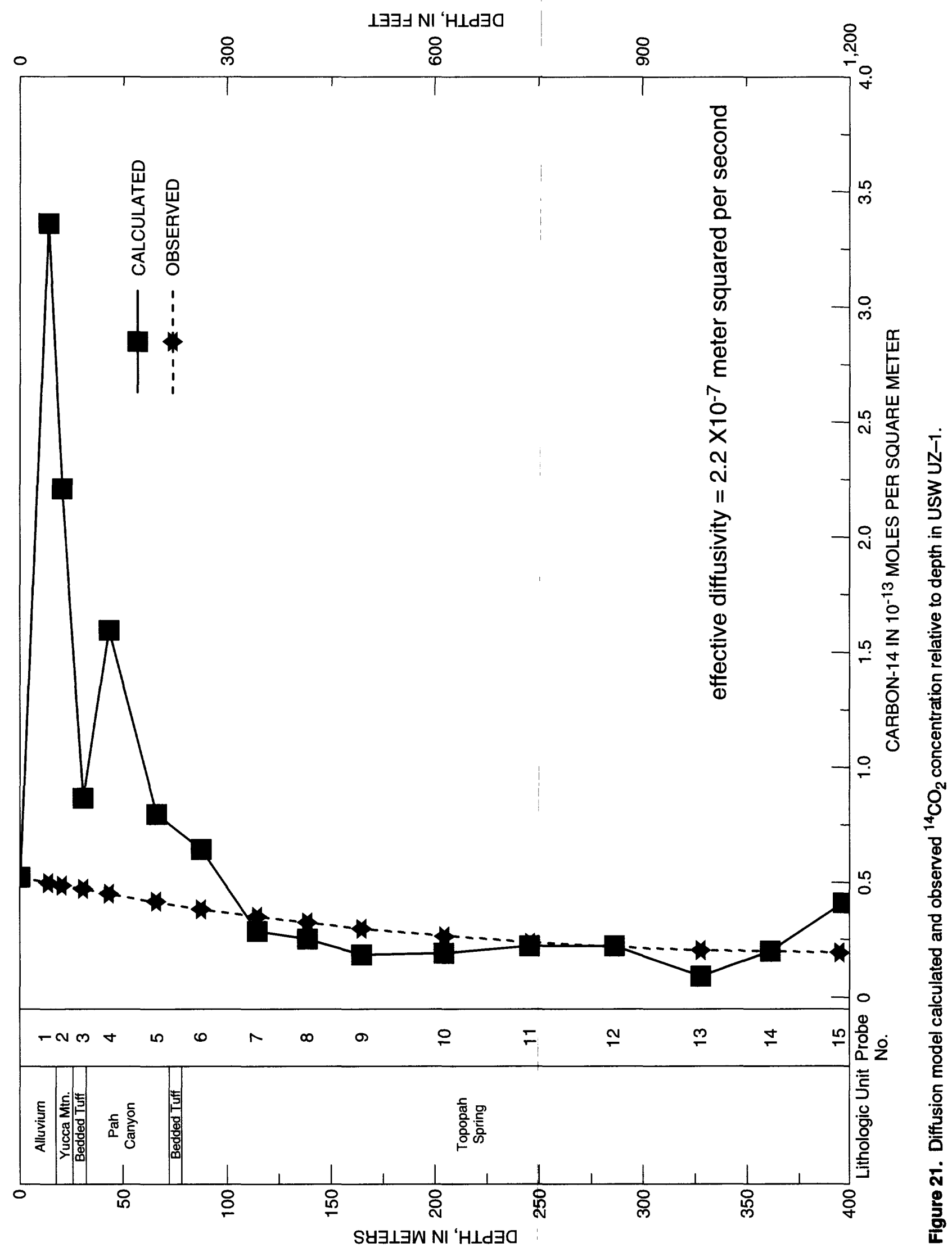


where

$C_{\text {out }}(t)=$ output tritium concentration at time $t$, expressed in calendar year 19xx (not number of years);

$C_{i n}(t)=$ tritium concentration of fluid recharging the system;

$T=$ residence time; and

$\lambda=$ tritium decay constant $\left(5.576 \times 10^{-2} / \mathrm{yr}\right)$.

This equation can be solved by the analytical method for tritium concentrations relative to residence times with known tritium input function.

\section{Well-Mixed Model}

On the other hand, the well-mixed model assumes that all sources of water input to the reservoir are completely mixed with the water already in the reservoir. For such a reservoir, it is assumed that volume does not change with time and input rate equals the output rate $\left(Q_{i n}=Q_{o u t}\right)$. The mass-balance equation presented by Pearson and Truesdell (1978) is given as follows:

$$
\frac{d C(t)}{d t}=\frac{Q_{\text {in }} C_{i n}(t)}{V}-\frac{Q_{o u t} C(t)}{V}-\lambda C(t)
$$

where

$C(t)=$ the tritium level in the reservoir, and at the discharge point, at time $t$;

$C_{i n}(t)=$ input tritium concentration;

$Q_{\text {in }}=$ recharge flow rate, $Q_{\text {in }}=Q_{\text {oui }} ;$

$Q_{\text {out }}=$ discharge flow rate;

$V=$ volume of reservoir, constant;

$t=$ residence time, $V / Q$; and

$\lambda=$ decay constant of tritium $\left(5.576 \times 10^{-2} / \mathrm{yr}\right)$.

This differential equation can easily be solved by the numerical method with a known tritium input function.

\section{Tritium Input Function}

In order to evaluate the end-member models, the tritium concentration of recharge water before and after nuclear testing must be estimated in the study area. Prior to 1952 , little tritium data were reported. A few measurements were made on lake water, ground water, and wines from Chicago and New York areas. These measurements indicate that the average natural background tritium value for the interior of North America is about $6 \mathrm{TU}$, depending on the latitude and altitude (Craig and Lal, 1961; Kaufman and Libby, 1954). Also, tritium values in precipitation were reported by Payne (1972) to be between 2 and 25 TU prior to the 1950's. Tritium

data in precipitation at Yucca Mountain were reported by Milne and others (1987) from November 1983 to June 1985 only. Other reported data, not from Yucca Mountain but from States neighboring Nevada, are available from stations set up by the International Atomic Energy Agency (IAEA) in Menlo Park, Calif., Albuquerque, N. Mex., Flagstaff, Ariz., and Salt Lake City, Utah. The averaged data from these four stations were taken to represent the Yucca Mountain area even though there are differences in latitude, altitude, and local climatic conditions between these four stations and Yucca Mountain. The average monthly tritium concentration in precipitation has been reported by IAEA for these four stations since 1963 (International Atomic Energy Agency, 1969-1986). However, no data were reported from 1953 to 1962 . To estimate the pre-1963 tritium concentrations for the four stations, the IAEA data from Ottawa in Canada, which has a complete record of tritium values in precipitation since 1953, were used to formulate the tritium input data. This same method was also used by Pearson and Truesdell (1978), Campana and Mahin (1985), Knott and Olimpio (1986), and Shevenell (1991).

The IAEA tritium data, reported as a monthly average, increases in concentration during the spring and summer. The long-term precipitation records of Las Vegas, Nev., also show increases in tritium concentrations in spring and summer (Cayan and others, 1991). Annual average value and maximum monthly value of each year from IAEA were used as input functions for these models.

To estimate the missing tritium data at these stations between 1953 and 1962, trends of tritium concentration at these stations are assumed to be similar to the tritium concentrations in the Ottawa station. The best-fit linear regression equations for four stations and their correlation coefficient $\left(\mathrm{R}^{2}\right)$ are shown below. Using annual average:

$$
\begin{aligned}
\mathrm{Y}_{1}= & 0.960393 \mathrm{X}_{1}-0.07485 \quad \mathrm{R}^{2}=0.9015 \\
& \text { (estimated linear equation at Flagstaff) } \\
\mathrm{Y}_{2}= & 1.168409 \mathrm{X}_{1}-0.36611 \mathrm{R}^{2}=0.9622 \\
& \text { (estimated linear equation at Salt Lake } \\
& \text { City) } \\
\mathrm{Y}_{3}= & 1.080147 \mathrm{X}_{1}-0.37512 \mathrm{R}^{2}=0.944 \\
& \text { (estimated linear equation at Albuquerque) } \\
\mathrm{Y}_{4}= & 0.745824 \mathrm{X}_{1}-0.36611 \quad \mathrm{R}^{2}=0.799 \\
& \text { (estimated linear equation at Albuquerque) }
\end{aligned}
$$


where

$Y_{1}=\log$ (annual ${ }^{3} \mathrm{H}$ concentration at Flagstaff),

$\mathrm{X}_{1}=\log$ (annual ${ }^{3} \mathrm{H}$ concentration at Ottawa)

$\mathrm{Y}_{2}=\log$ (annual ${ }^{3} \mathrm{H}$ concentration at Salt Lake City)

$\mathrm{Y}_{3}=\log$ (annual ${ }^{3} \mathrm{H}$ concentration at Albuquerque)

$\mathrm{Y}_{4}=\log$ (annual ${ }^{3} \mathrm{H}$ concentration at Menlo Park)

Similarly, using maximum monthly value of each year:

$\mathrm{Y}_{1}=1.099583 \mathrm{X}_{1}-0.36034 \mathrm{R}^{2}=0.904$

(estimated linear equation at Flagstaff)

$\mathrm{Y}_{2}=1.195766 \mathrm{X}_{1}-0.45923 \mathrm{R}^{2}=0.908$

(estimated linear equation at Salt Lake

City)

$\mathrm{Y}_{3}=1.129000 \mathrm{X}_{1}-0.44896 \mathrm{R}^{2}=0.887$

(estimated linear equation at Albuquerque)

$\mathrm{Y}_{4}=0.905918 \mathrm{X}_{1}-0.29431 \mathrm{R}^{2}=0.790$

(estimated linear equation at Albuquerque)

where

$Y_{1}=\log$ (maximum monthly value of ${ }^{3} \mathrm{H}$ concentration at Flagstaff),

$\mathrm{Y}_{2}=\log$ (maximum monthly value of ${ }^{3} \mathrm{H}$ concentration at Salt Lake City)

$\mathrm{Y}_{3}=\log$ (maximum monthly value of ${ }^{3} \mathrm{H}$ concentration at Albuquerque)

$\mathrm{Y}_{4}=\log$ (maximum monthly value of ${ }^{3} \mathrm{H}$ concentration at Menlo Park)

The average of the tritium concentration at the four stations is assumed to represent the concentration at Yucca Mountain (figs. 22A and 22B). The most notable feature of the concentration profile is that the maximum tritium concentrations in precipitation, approximately 250 times above background levels, occurred in 1963. The estimated annual average tritium concentration of 1984 is $23.0 \mathrm{TU}$, which is close to the measured tritium concentration (19.7 TU) in precipitation at Yucca Mountain (Milne and others, 1987).

\section{Results of Tritium Model Calculations}

Pre-1952 tritium concentrations in precipitation ranging from 5 to $20 \mathrm{TU}$ are used as an initial concentrations for input into the well-mixed model sensitivity analyses. The results indicate that the output tritium concentrations change insignificantly. Therefore, a pre-1952 tritium concentration of 6 TU was adopted for the annual average value, and 12 TU was adopted for the maximum monthly average value.

Figures $23 \mathrm{~A}$ and $23 \mathrm{~B}$ show the calculated tritium concentrations relative to mean residence times for the two end-member cases for the samples collected in 1993 at Yucca Mountain (a) using an annual mean value, and (b) using the highest monthly tritium value in a year in precipitation as input functions. The curve for the piston-flow model indicates several peak concentrations of tritium, reflecting the various nuclear-test series begun in 1953. On the other hand, mixed-reservoir curves show smooth increases in the tritium content of a reservoir caused by high tritium inputs from the mid-1950's to 1963 , followed by a decrease to the present (1995) level. It is important to note that the piston-flow model using the highest monthly value in figure 23B gives the highest tritium concentrations of up to $700 \mathrm{TU}$, in 1993 with residence time of 30 years, from 1963 nuclear-test fallout. The highest tritium concentration in the well-mixed reservoir is only about $55 \mathrm{TU}$. Using the annual mean value from the closest four stations for tritium concentration in precipitation, the piston-flow model gives $350 \mathrm{TU}$ as a maximum, and the well-mixed model gives $25 \mathrm{TU}$ as a maximum in ground water in 1993. The piston-flow model with either type of input function can account for the observed tritium peaks of more than $100 \mathrm{TU}$ in the Calico Hills Formation of UE-25 UZ\#16. However, the well-mixed model cannot account for the observed values.

In reality, no hydrologic system should be expected to exhibit pure piston-flow or pure wellmixed flow behavior. The results of piston-flow and well-mixed flow models only give the lower and upper limits of peak tritium concentrations for various residence times. Although tritium, with its short half-life, cannot be used rigorously to obtain an accurate mean residence time of an older water, this study demonstrates that it can be used to obtain an order of magnitude estimate of a residence time.

Extremely variable tritium values in the USW UZ-14 and UE-25 UZ\#16 profiles indicate unsaturated-zone waters are not well mixed (as seen from tritium model calculation) but are transported in large part by piston flow (between piston and well-mixed flows, but closer to a piston flow). Therefore, preferential flow through fractures is the dominant mechanism. Other evidence of fracture flow is supported by the presence of many calcite and silica deposits in fractures, boreholes, and the Exploratory Study Facilities. Also, water was observed to seep out from the fractures in several boreholes. Large tritium concentrations in borehole UZ\#16 in the Calico Hills Formation are within limits of piston-flow-model calculation (about 30 years' residence time). 

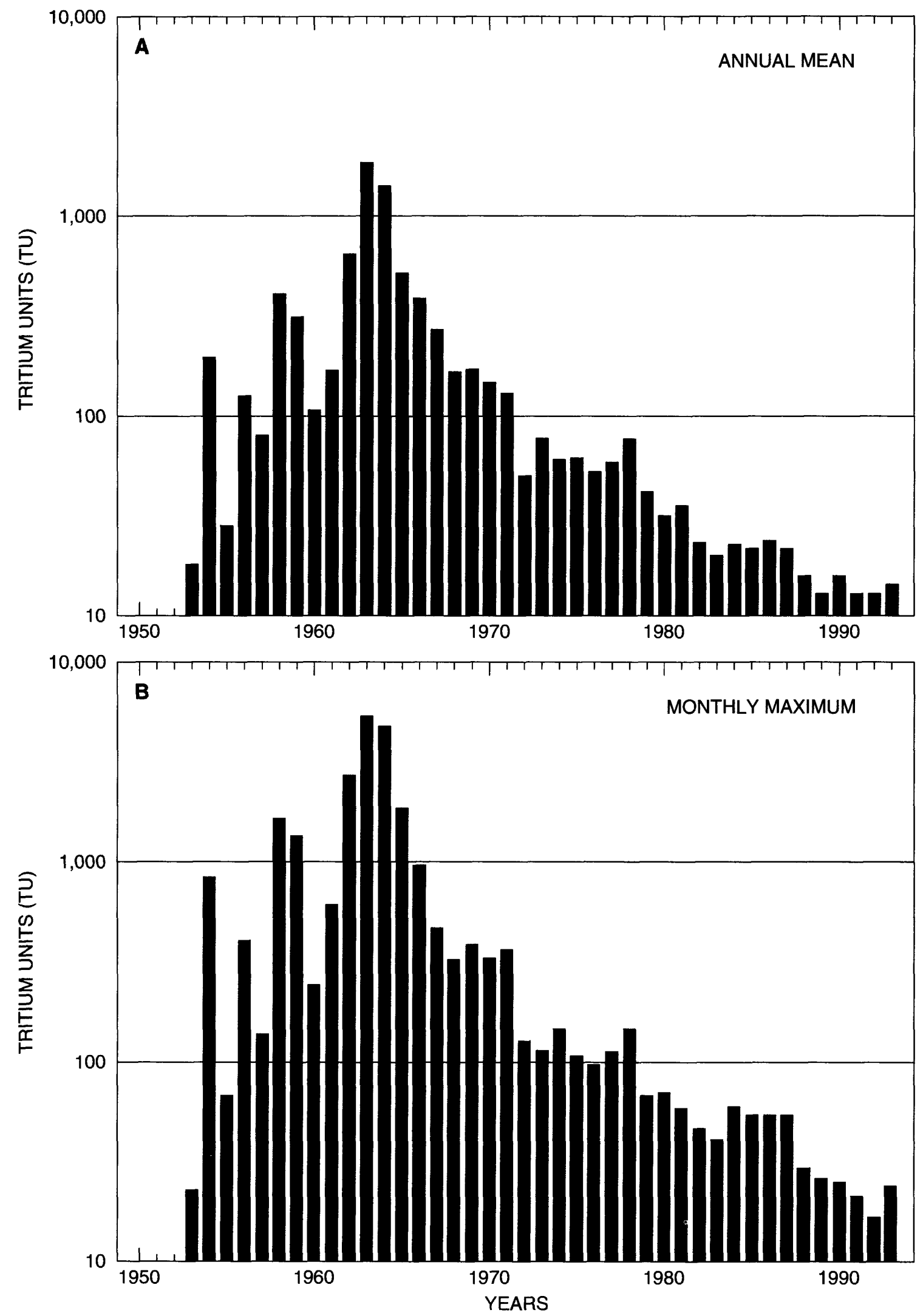

Figure 22. Tritium input function derived from (A) annual mean value, and $(B)$ highest monthly value in a year of tritium concentration in precipitation from four stations: Albuquerque, New Mexico; Flagstaff, Arizona; Menlo Park, California; and Salt Lake City, Utah. 
A

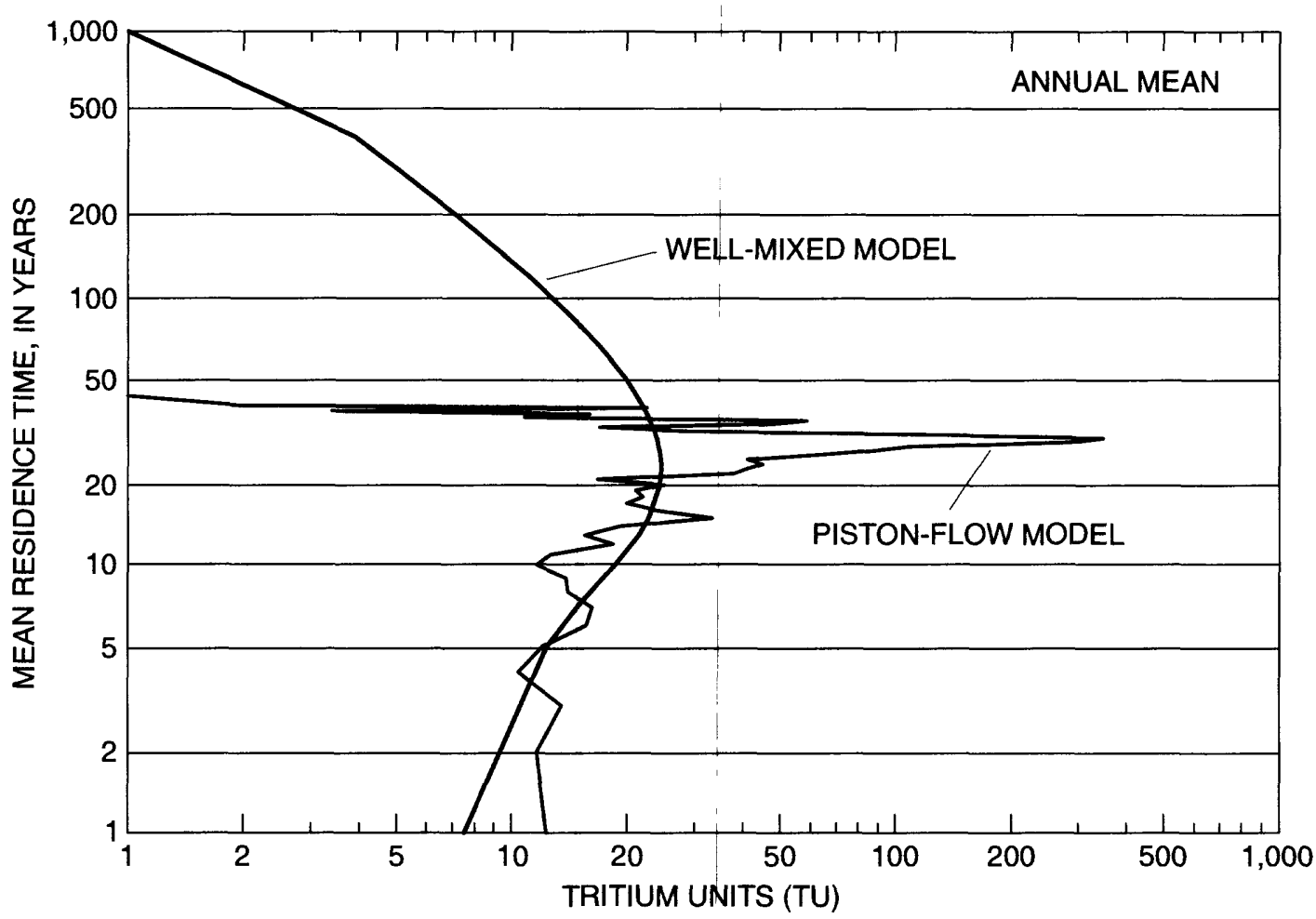

B

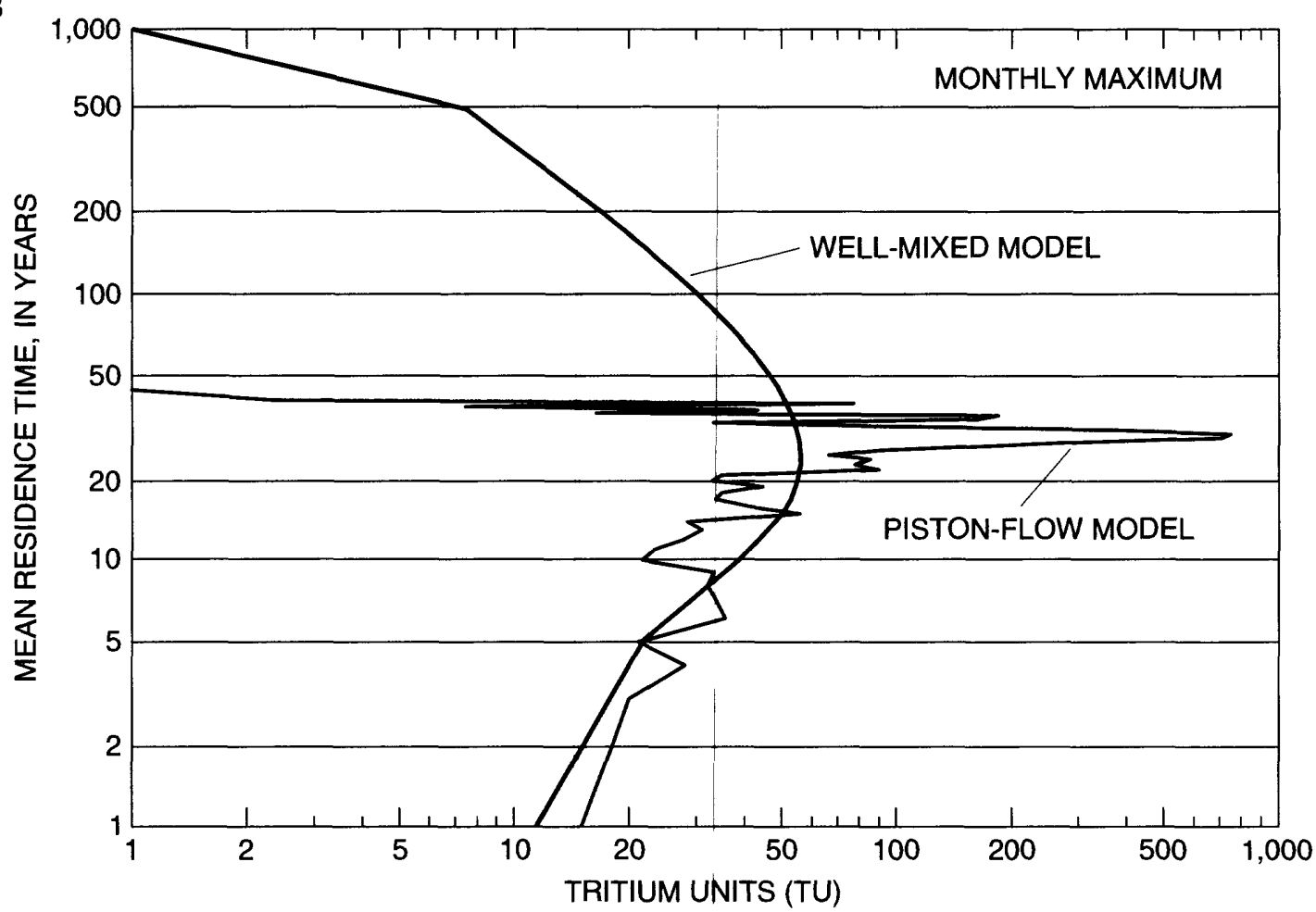

Figure 23. Calculated tritium contents of water in the unsaturated zone by piston-flow and well-mixed models using (A) annual mean value of tritium input function (fig. 22A), and (B) highest monthly value of tritium input function (fig. 22B). 


\section{SUMMARY AND CONCLUSIONS}

Unsaturated-zone pore water generally has significantly larger concentrations of dissolved solids than either the saturated-zone water or perched water. Pore-water composition plotted on Piper diagrams define groups related to lithologic units. Pore waters in the Tiva Canyon, Yucca Mountain, Pah Canyon, and bedded tuffs are calcium sulfate or calcium chloride types that group together near the top of the diamond on the Piper diagram. Calico Hills Formation waters are sodium carbonate or bicarbonate type and plot near the bottom of the diamond. Pore waters in the Topopah Spring Tuff are at the middle of the diamond.

Tritium profiles show inversions occurred in several places. These inversions indicate that vertical water percolation through the matrix is not the normal flow mechanism at Yucca Mountain. Rather, fracture flow is the dominant fluid-flow mechanism. The postbomb tritium concentrations observed in the Calico Hills Formation of UE-25 UZ\#16 are also supported by the young ${ }^{14} \mathrm{C}$ ages and modern ${ }^{36} \mathrm{Cl}$ signals found in the same locations. However, total water flux to the Calico Hills Formation is small.

Large ${ }^{14} \mathrm{C}$ variations of about 53 to $97.7 \mathrm{pmc}$ are seen in UE-25 UZ\#16 bedded tuff and in the Calico Hills Formation. Three values ranging from 53 to 61 pmc values in the Calico Hills Formation are in agreement with observed values in perched water. Many of the ${ }^{14} \mathrm{C}$ values in the Calico Hills Formation of USW UZ-14 are between 80 and $95 \mathrm{pmc}$ (equivalent to apparent ${ }^{14} \mathrm{C}$ ages of about 1,800 and 400 years), although one value is $70 \mathrm{pmc}$. Further investigations are in progress to confirm these apparent young ${ }^{14} \mathrm{C}$ ages.

Chemical and isotopic compositions of the perched water indicated that (1) the apparent ${ }^{14} \mathrm{C}$ ages of perched water are similar to apparent ${ }^{14} \mathrm{C}$ ages of the Calico Hills Formation pore water in UE-25 UZ\#16, ranging from 3,000 to 7,000 years; (2) stable isotopic values of -12.1 to $-13.8 \%$ for $\delta^{18} \mathrm{O}$ and -87.4 to $-100 \%$ for $\delta \mathrm{D}$ in perched water strongly support the postglacial ${ }^{14} \mathrm{C}$ ages; (3) the hydrogen and oxygen isotopic compositions of perched-water samples indicate that perched water rapidly infiltrated into fractures; (4) chloride concentrations of the perched water indicate that perched waters were recharged mainly from fracture waters with little contribution from matrix water; and (5) major-ion chemistry indicates that most perched waters have similar chemical compositions to the saturated-zone ground water except the perched water in USW UZ-14, which is typical of Topopah Spring Tuff water.

Rock-gas compositions are similar to the atmospheric air except that $\mathrm{CO}_{2}$ concentrations are generally larger than in air. The $\delta^{13} \mathrm{C}$ (gas) values of USW UZ-1 are fairly constant from the surface to $365.8 \mathrm{~m}$, indicating little interaction between the gas $\mathrm{CO}_{2}$ and caliche in the soil. With regard to gas-water exchange, most of the carbon is in the aqueous phase. Consequently, an aqueous-phase ${ }^{14} \mathrm{C}$ age will affect a gaseous-phase ${ }^{14} \mathrm{C}$ age more than the converse. The reason for the nonequilibrium condition observed between the two phases is probably due to the fact that most of the gas was collected from fractures rather than from pores where equilibrium conditions may exist. Carbon-14 ages in the gaseous phase are significantly older than the water ${ }^{14} \mathrm{C}$ ages in the deep Topopah Spring Tuff and subadjacent units. The observed apparent age differences may result from liquid-gravity fracture flow, a process faster than gas-diffusion flow.

Model calculations indicate that gas transport in the unsaturated zone of Yucca Mountain agrees well with the steady-state diffusion and decay process, based on the ${ }^{14} \mathrm{C}$ data from USW UZ-1. Tritiummodeling results indicate that the high tritium value of about 100 TU in the Calico Hills Formation of UZ\#16 is within limits of a piston-flow model with residence time of about 30 years. The large variations in tritium values with narrow peaks suggest an aqueous-phase flow in the unsaturated zone that is closer to a piston or preferential fracture flow than to a matrix flow.

\section{REFERENCES}

Benson, L.V., and McKinley, P.W., 1985, Chemical composition of ground water in the Yucca Mountain area, Nevada, 1971-84: U.S. Geological Survey Open-File Report 85-484, $10 \mathrm{p}$.

Bird, R.B., Stewart, W.E., and Lightfoot, E.N., 1960, Transport phenomena: New York, John Wiley, 780 p.

Campana, M.E., and Mahin, D.A., 1985, Model-derived estimates of groundwater mean ages, recharge rates, effective porosities and storage in a limestone aquifer: Journal of Hydrology, v. 76, no. 3-4, p. 247-264.

Carmi, I., and Gat, J.R., 1973, Tritium in precipitation and freshwater sources in Israel: Israeli Journal of Earth Sciences, v. 22, no. 2, p. 71-92. 
Cayan, D.R., McLain, D.R., Nichols, W.D., and DiLeo-Stevens, J.S., 1991, Monthly climatic time series data the Pacific Ocean and western Americas: U.S. Geological Survey Open-File Report 91-92, $380 \mathrm{p}$.

Craig, Harmon, 1961, Isotopic variations in meteoric waters: Science, v. 133, no. 3465, p. 1702-1703.

Craig, Harmon, and Lal, D., 1961, The production rate of nature tritium: Tellus, v. 13, p. 85-105.

Dansgaard, W., 1964, Stable isotopes in precipitation: Tellus, v. 16, no. 4, p. 436-468.

Davis, S.N., and Bentley, H.W., 1982, Dating groundwater in nuclear and chemical dating techniques, in Currie, L.A., ed., Interpreting the environmental record: Washington, D.C., American Chemical Society, Symposium series 176, p. 193.

Egboka, B.C.E., Cherry, J.A., Farrolden, R.N., and Frind, E.O., 1983, Migration of contaminants in groundwater at a landfill - A case study -3 , Tritium as an indicator of dispersion and recharge: Journal of Hydrology, v. 63, no. 1-2, p. 51-80.

Friedman, Irving, and O'Neil, J.R., 1977, Compilation of stable isotope fractionation factors of geochemical interest: U.S. Geological Survey Professional Paper 440-KK.

Haas, H.H., Fisher, D.W., Thorstenson, D.C., and Weeks, E.P., $1983,{ }^{13} \mathrm{CO}_{2}$ and ${ }^{14} \mathrm{CO}_{2}$ measurements on soil atmosphere sampled in the subsurface unsaturated zone in the western Great Plains of the U.S.: Radiocarbon, v. 25, no. 2, p. 301-314.

Houghton, S.B., 1969, Vacuum drilling: Mercury, Nev., Fenix \& Scisson, Inc., Office Engineering Division, 32 p. (NNA.900208.0105)

IAEA (International Atomic Energy Agency), 1969-1986, Environmental isotope data No. 1-8: World survey of isotope concentration in precipitation (1953-1963, 1964-1965, 1966-1967, 1968-1969, 1970-1971, 1972-1975, 1976-1979, and 1980-1983); and Technical Report Series 96, 117, 129, 147, 165, 192, 226, and 264, IAEA, Vienna, 1969, 1971, 1973, 1975, 1979, 1983, and 1986.

Kaufman, S., and Libby, W.F., 1954, The natural distribution of tritium: Review of Physics, v. 93, no. 6, p. 1337-1344.

Knott, J.F., and Olimpio, J.C., 1986, Estimation of recharge rates to the sand and gravel aquifer using environmental tritium, Nantucket Island, Massachusetts: U.S. Geological Survey Water-Supply Paper 2297, $26 \mathrm{p}$.

Liu, B., Fabryka-Martin, J., Wolfsberg, A., Robinson, B., and Sharma, P., 1995, Significance of apparent discrepancies in water ages derived from atmospheric radionuclides at Yucca Mountain, Nevada, in Hotchkiss, W.R., Downey, J.S., Gutentag, E.D., and
Moore, J.E., eds., Water resources at risk, a selection of the papers presented at the conference held in Denver, Colo., May 14-18, 1995: American Institute of Hydrology, p. NH-52-NH-62.

Loskot, C.L., and Hammermeister, D.P., 1992, Geohydrologic data from test holes UE-25 UZ\#4 and UE-25 UZ\#5, Yucca Mountain area, Nye County, Nevada: U.S. Geological Survey Open-File Report 90-369, $56 \mathrm{p}$.

Michael, R.L., 1989, Tritium deposition in the continental United States, 1953-83: U.S. Geological Survey Water-Resources Investigations Report 89-4072, $46 \mathrm{p}$.

Milne, W.K., Benson, L.V., and McKinley, P.W., 1987, Isotope content and temperature of precipitation in southern Nevada, August 1983-August 1986: U.S. Geological Survey Open-File Report 87-463, $32 \mathrm{p}$.

Montazer, Parviz, Weeks, E.P., Thamir, Falah, Yard, S.N., and Hofrichter, P.B., 1985, Monitoring the vadose zone in fractured tuff, Yucca Mountain, Nevada, in National Water Well Association Conference on Characterization and Monitoring of the Vadose (Unsaturated) Zone, Denver, Colo., November 19-21, 1985, Proceedings: Denver, Colo., National Water Well Association, p. $439-469$.

Montazer, Parviz, and Wilson, W.E., 1984, Conceptual hydrologic model of flow in the unsaturated zone, Yucca Mountain, Nevada: U.S. Geological Survey Water-Resources Investigations Report 84-4345, $55 \mathrm{p}$.

Mower, T.E., Higgins, J.D., and Yang, I.C., 1991, Porewater extraction from unsaturated tuffs using onedimensional compression, in High-level radioactive waste management, international conference, $2 \mathrm{~d}$, Las Vegas, Nev., April 28-May 3, 1992, Proceedings: Las Vegas, Nev., p. 989-1006.

Mower, T.E., Higgins, J.D., Yang, I.C., and Peters, C.A., 1994, Pore-water extraction from unsaturated tuff by triaxial and one-dimensional compression methods, Nevada Test Site: U.S. Geological Survey WaterResources Investigations Report 93-4144, 79 p.

Nir, A., 1964, On the interpretation of tritium age measurements in groundwater: Journal of Geophysical Research, v. 69, no. 12 , p. 2589-2595.

Payne, B.R., 1972, Isotope hydrology, in Chow, V.T., ed., Advances in hydroscience, v. 8: New York, Academic Press, p. 95-138.

Pearson, F.J., and Truesdell, A.H., 1978, Tritium in the water of Yellowstone National Park, in Zartman, R.E., ed., Short papers of the 4th international conference, geochronology, cosmochronology, isotope geology, August 20-25, 1978, Snowmass-at-Aspen, Colo.: U.S. Geological Survey Open-File Report 78-701, p. 327-329. 
Peters, C.A., Striffler, P.S., Yang, I.C., Ferarese, J.S., 1991, Field testing the effectiveness of pumping to remove sulfur hexafluoride traced drilling air from a prototype borehole near Superior, Arizona, in Proceedings, Workshop 5-Flow and transport through unsaturated fractured-rock-related to high-level radioactive waste disposal: Tucson, Arizona, January 7-10, 1991, p. 79-83. (NUREG/CP-0040)

Peters, C.A., Yang, I.C., Higgins, J.D., and Burger, P.A., 1992, A preliminary study of the chemistry of pore water extracted from tuff by one-dimensional compression: Proceedings, International Symposium on Water-Rock Interaction, 7th (WRI-7), Park City, Utah, July 13-18, 1992, p. 741-745.

Quiring, R.F., 1983, Precipitation climatology of the Nevada Test Sites: U.S. National Weather Service Report WSNSO 351-88, 34 p. (NNA.870406.0324)

Scott, R.B., and Bonk, Jerry, 1984, Preliminary geologic map of Yucca Mountain, Nye County, Nevada, with geologic sections: U.S. Geological Survey Open-File Report 84-494, 10 p., scale 1:12,000.

Shevenell, Lisa, 1991, Tritium in the thermal water discharging in Loowit Canyon, Mount St. Helens, Washington, U.S.A: Chemical geology; Isotope-Geoscience Section, v. 94, no. 2 , p. $123-135$.

Simpson, B., and Carmi, I., 1983, The hydrology of the Jordan tributaries (Israel)-Hydrolographic and isotopic investigation: Journal of Hydrology, v. 62, no. 1-4, p. 225-242.

Spengler, R.W., Braun, C.A., Martin, L.G., and Weisenberg, C.W., 1994, The Sundance Fault-A newly recognized shear zone at Yucca Mountain, Nevada: U.S. Geological Survey Open-File Report 94-49, 11 p.

Spengler, R.W., Byers, F.M., Jr., and Warner, J.B., 1981, Stratigraphy and structure of volcanic rocks in drill hole USW G-1, Yucca Mountain, Nye County, Nevada: U.S. Geological Survey OpenFile Report 81-1349, $50 \mathrm{p}$.

Stewart, C.L., 1972, Clay-water interaction, the behaviour of ${ }^{3} \mathrm{H}$ and ${ }^{2} \mathrm{H}$ in absorbed water, and the isotope effect: Proceedings, Soil Science Society of America, v. 36, no. 3, p. 421-426.

Striffler, P.S., and Peters, C.A., 1993, Effects of core sealing methods on the preservation of pore water: Proceedings of the Fourth Annual International Conference on HighLevel Radioactive Waste Management, Las Vegas, Nevada, April 26-30, 1993, p. 960-966.

Szabo, B.J., and Kyser, T.K., 1985, Uranium, thorium isotopic analyses and uranium-series ages of calcite and opal, and stable isotopic compositions of calcite from drill cores UE-25a \#1, USW G-2, and USW G-3/GU-3, Yucca Mountain, Nevada: U.S. Geological Survey Open-File Report 85-224, $30 \mathrm{p}$.
Thatcher, L.L., Janzer, V.J., and Edwards, K.W., 1977, Methods for determination of radioactive substances in water and fluvial sediments: Book 5, chapter A5 of Techniques of water-resources investigations of the United States Geological Survey, $243 \mathrm{p}$.

Thorstenson, D.C., Haas, Herbert, Peters, C.A., and Yang, I.C., 1995, The reactions and transport of $\mathrm{CO}_{2}$ and its $\mathrm{C}$-isotopes in the unsaturated zone at the crest of Yucca Mountain, Nevada: U.S. Geological Survey Administrative Report.

Thorstenson, D.C., and Pollock, D.W., 1989, Gas transport in unsaturated zones-Multicomponent systems and the adequacy of Fick's laws: Water Resources Research, v. 25 , no. 3, p. 477-507.

Thorstenson, D.C., Weeks, E.P., Haas, H.H., and Fisher, D.W., 1983, Distribution of gaseous ${ }^{12} \mathrm{CO}_{2},{ }^{13} \mathrm{CO}_{2}$, and ${ }^{14} \mathrm{CO}_{2}$ in the subsoil unsaturated zone of the western U.S. Great Plains: Radiocarbon, v. 25, no. 2, p. 315-346.

Thorstenson, D.C., Weeks, E.P., Haas, H.H., and Woodward, J.C., 1990, Physical and chemical characteristics of topographically affected airflow in an open borehole at Yucca Mountain, Nevada, in Nuclear waste isolation in the unsaturated zone, Focus '89, Sept. 17-21, 1990, Las Vegas, Nev., Proceedings: Las Vegas, Nev., p. 256-270.

Vuataz, F.D., and Goff, Fraser, 1986, Isotope geochemistry of thermal and nonthermal water in the Valles caldera, Jemez Mountains, northern New Mexico: Journal of Geophysical Research, v. 91, no. B2, p. 1835-1853.

Walker, G.R., Wood, P.H., and Allision, G.B., 1991, Interlaboratory comparison of method to determine the stable isotope composition of soil water: International Atomic Energy Agency, paper no. IAEA-SM319, p. 509-517.

Weeks, E.P., 1987, Effect of topography on gas flow in unsaturated fractured rock, in Evans, D.D., and Nicholson, T.J., eds., Geophysical Monograph 42: American Geophysical Union, p. 165-170.

Whelan, J.F., and Stuckless, J.S., 1992, Paleohydrologic implications of the stable isotopic composition of secondary calcite within the Tertiary volcanic rocks of Yucca Mountain, Nevada, in High-level radioactive waste management, international conference, 3d, Las Vegas, Nev., April 12-16, 1992, Proceedings: Las Vegas, Nev., p. 1572-1581.

Whelan, J.F., Vaniman, D.T., Stuckless, J.S., and Moscati, R.J., 1994, Paleoclimatic and paleohydrologic records from secondary calcite, Yucca Mountain, Nevada, in High-level radioactive waste management, international conference, 5th, Las Vegas, Nev., May 22-26, 1994, Proceedings: Las Vegas, Nev., p. 2738-2745. 
Whitfield, M.S., 1985, Vacuum drilling of unsaturated tuffs at a potential radioactive-waste repository, Yucca Mountain, Nevada, in National Water Well Association conference on characterization and monitoring of the vadose (unsaturated) zone, Denver, Colo., November 19-21, 1985, Proceedings: Denver, Colo., National Water Well Association, p. 413-423.

Whitfield, M.S., Thordarson, William, and Hammermeister, D.P., 1990, Drilling and geohydrologic data for test hole USW UZ-1, Yucca Mountain, Nye County, Nevada: U.S. Geological Survey OpenFile Report 90-354, $40 \mathrm{p}$.

Yang, I.C., 1992, Flow and transport through unsaturated rock-Data from two test holes, Yucca Mountain, Nevada, in High-level radioactive waste management, international conference, 3d, Las Vegas, Nev., April 12-16, 1992, Proceedings: Las Vegas, Nev., p. $732-737$.

Yang, I.C., Davis, G.S., and Sayer, T.M., 1990, Comparison of pore-water extraction by triaxial compression and high-speed centrifugation method, in Zaporozec, Alexander, ed., Minimizing risk to the hydrologic environment: Dubuque, Iowa, Kendall/Hunt Publishing Company, p. 250-259.

Yang, I.C., Herbert, H.H., Weeks, E.P., and Thorstenson, D.C., 1985, Analysis of gaseous-phase stable and radioactive isotopes in the unsaturated zone, Yucca Mountain, Nevada, in National Water Well Association conference on characterization and monitoring of the vadose (unsaturated) zone, Denver, Colo. November 19-21, 1985, Proceedings: Denver, Colo., National Water Well Association, p. 488-506.

Yang, I.C., Peters, C.A., and Thorstenson, D.C., 1993, Carbon isotopic data from test hole USW UZ-1, Yucca Mountain, Nevada, in High-level radioactive waste management, international conference, 4th, Las Vegas, Nev., April 26-30, 1993, Proceedings: Las Vegas, Nev., p. 401-406.

Yang, I.C., Turner, A.K., Sayre, T.M., and Montazer, Parviz, 1988, Triaxial-compression extraction of pore water from unsaturated tuff, Yucca Mountain, Nevada: U.S. Geological Survey Water-Resources Investigations Report 88-4189,68 p. 


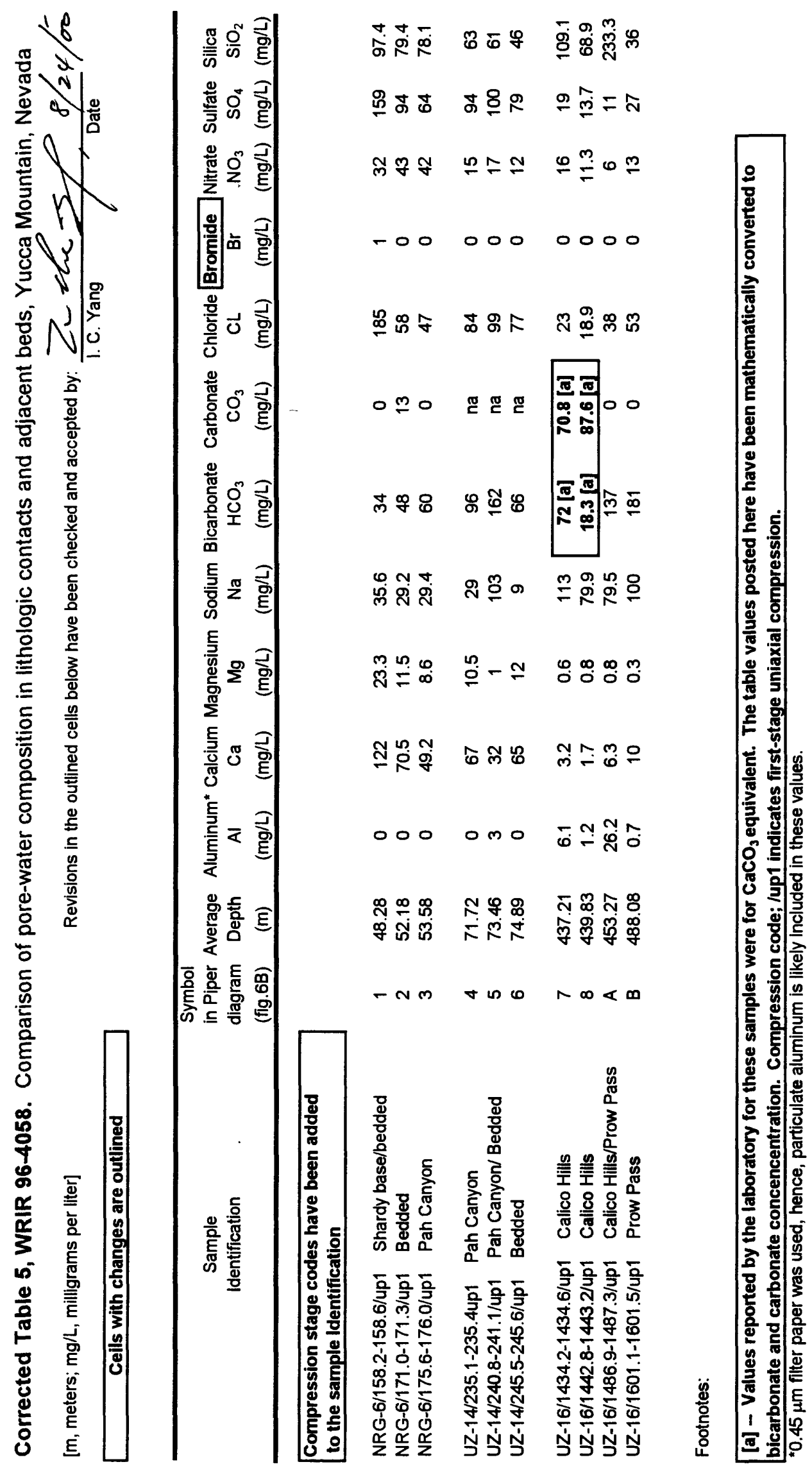




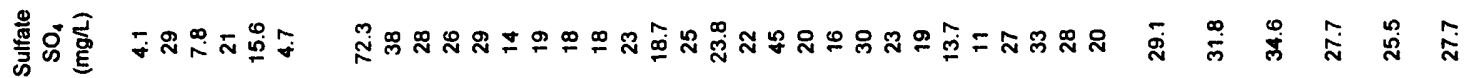

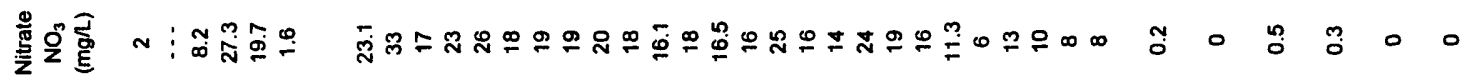
異

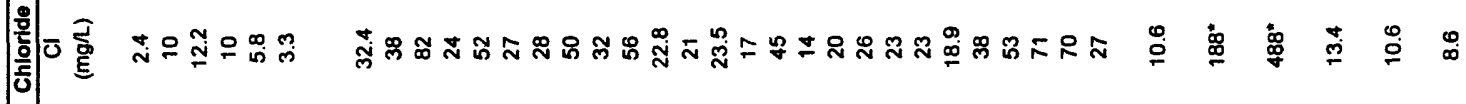
造总 㫕 茎

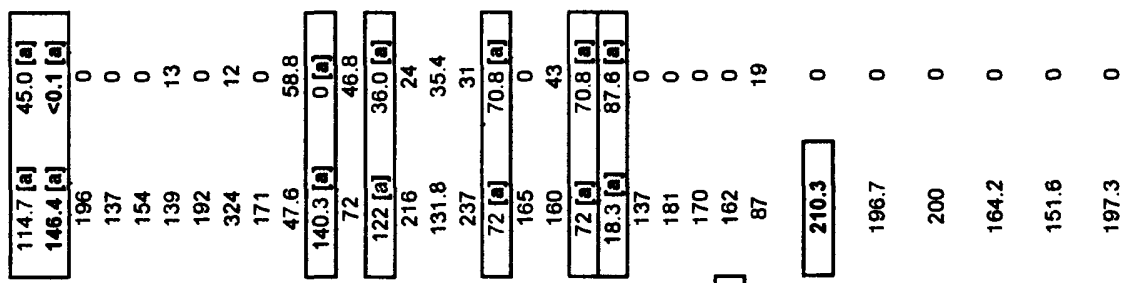

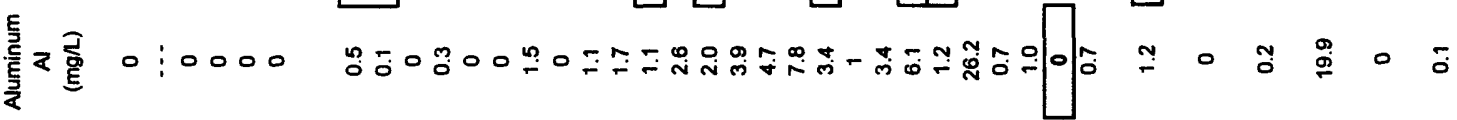

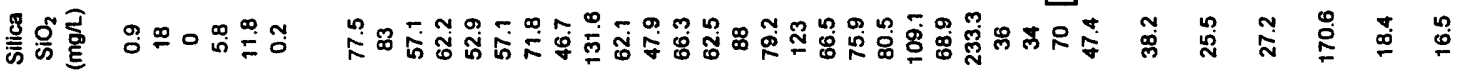

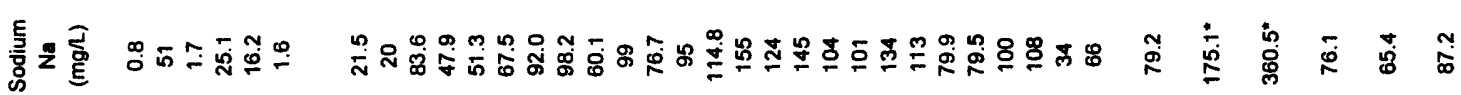

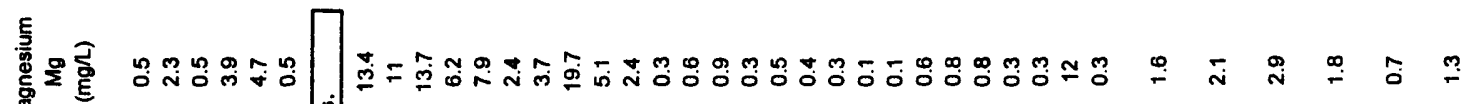

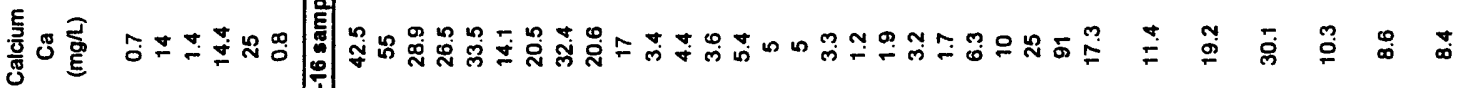
总兽总

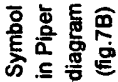

I

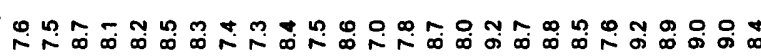

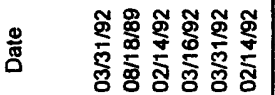

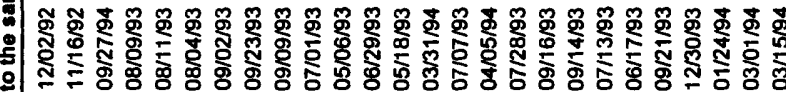

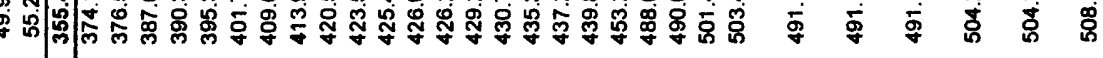


Corrected Table 1, WRIR 96-4058. Summary of relation of gravimetric water-content measurements of composite core to geologic unit and degree of welding for boreholes UE-25 UZ\#4 and UE-25 UZ\#5 ${ }^{1}$, Yucca Mountain, Nevada

\section{Cells with changes are outlined \\ [All water-content data in gram per gram; - -, indicated no data]}

The revision in the outlined cell below has been checked and accepted by:

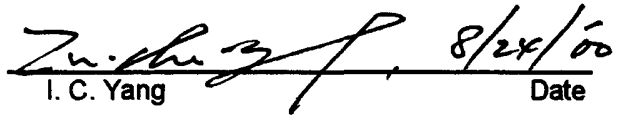

\begin{tabular}{|c|c|c|c|c|c|}
\hline \multirow{3}{*}{$\begin{array}{c}\text { Lithologic } \\
\text { Unit }\end{array}$} & \multicolumn{4}{|c|}{$\begin{array}{l}\text { Water Content, } \\
\text { gram/gram }\end{array}$} & \multirow{3}{*}{$\begin{array}{l}\text { Degree of } \\
\text { Welding }\end{array}$} \\
\hline & \multicolumn{2}{|c|}{ UE-25 UZ\#4 } & \multicolumn{2}{|c|}{ UE-25 UZ\#5 } & \\
\hline & Data Range & Average & Data Range & Average & \\
\hline Tiva Canyon & $0.036-0.042$ & 0.039 & $0.024-0.036$ & 0.030 & Densely welded \\
\hline Tiva Canyon & $0.061-0.063$ & 0.062 & $\ldots$ & - - & Moderately welded \\
\hline Tiva Canyon & $0.253-0.521$ & 0.363 & $0.145-0.290$ & 0.202 & Partly to nonwelded \\
\hline Yucca Mountain & $0.101-0.210$ & 0.157 & $0.059-0.143$ & 0.110 & Partly to nonwelded \\
\hline Pah Canyon & $0.092-0.182$ & 0.134 & $0.084-0.221$ & 0.122 & Partly to nonwelded \\
\hline Bedded Tuff & $0.069-0.391$ & 0.167 & $0.078-0.365$ & 0.176 & - \\
\hline Topopah Spring & - & -- & $0.221-0.279$ & 0.248 & Nonwelded \\
\hline Topopah Spring & $0.007-0.035$ & 0.020 & $0.011-0.015$ & 0.013 & Densely welded \\
\hline
\end{tabular}

${ }^{1}$ From Loskot and Hammermeister (1992) 


\title{
United States Department of the Interior
}

\author{
U. S. GEOLOGICAL SURVEY \\ Box 25046 M.S. 421 \\ Denver Federal Center \\ Denver, Colorado 80225
}

IN REPLY REFER TO:

\section{MEMORANDUM}

Date: August 31, 2000

To: Distribution

From: T. Brady, USGS, WRD, YMPB, Denver, CO

Subject: Publications -- Errata for USGS Water-Resources Investigations Report 96-4058

"Interpretation of Chemical and Isotopic Data from Boreholes in the Unsaturated Zone at Yucca Mountain, Nevada

This errata sheet corrects Tables 1,2 , and 5 of this report.

Please enclose this errata sheet with the distribution of this report.

Thank you for your cooperation with this request. If you have any questions that pertain to this matter, please contact Tim Brady at (303)236-5050, ext 249.

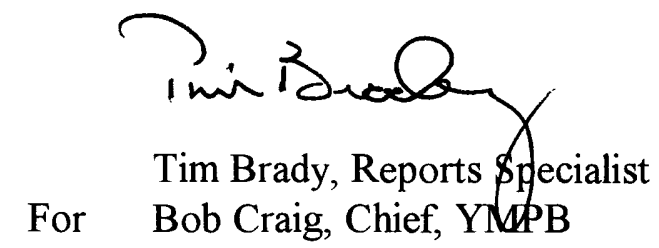

$\mathrm{BTM} / \mathrm{mm}$

Enclosure 